Portland State University

PDXScholar

2004

\title{
A nun's life : Barking Abbey in the late-medieval and early modern periods
}

Teresa L. Barnes

Portland State University

Follow this and additional works at: https://pdxscholar.library.pdx.edu/open_access_etds

Part of the European History Commons, and the History of Religion Commons Let us know how access to this document benefits you.

\section{Recommended Citation}

Barnes, Teresa L., "A nun's life : Barking Abbey in the late-medieval and early modern periods" (2004). Dissertations and Theses. Paper 948.

https://doi.org/10.15760/etd.948

This Thesis is brought to you for free and open access. It has been accepted for inclusion in Dissertations and Theses by an authorized administrator of PDXScholar. Please contact us if we can make this document more accessible: pdxscholar@pdx.edu. 


\section{THESIS APPROVAL}

The abstract and thesis of Teresa L. Barnes for the Master of Arts in History were presented April 23, 2004, and accepted by the thesis committee and the department.

COMMTTEE APPROVALS:

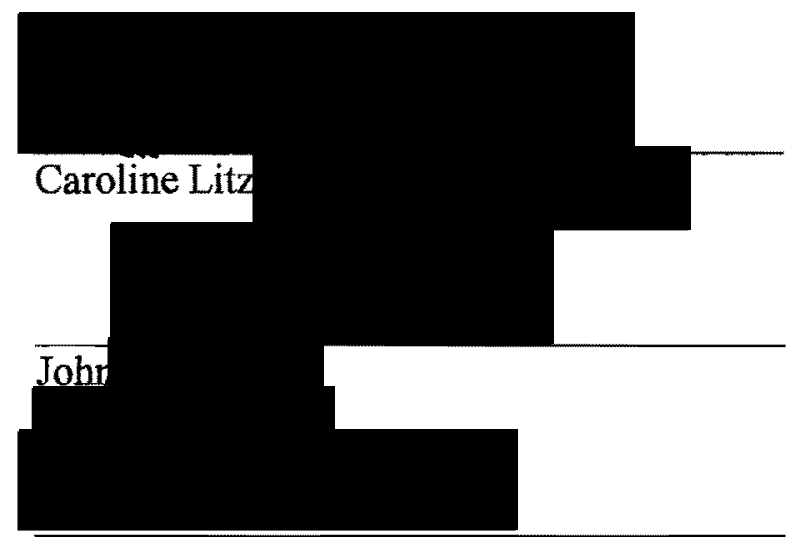

Thomas Luckett

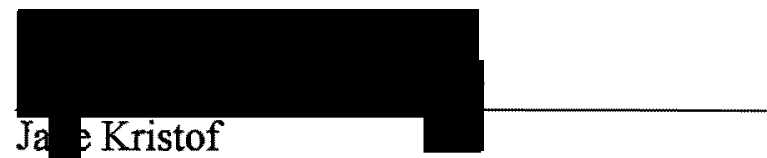

Representative of the Office of Graduate Studies

DEPARTMENT APPROVAL:

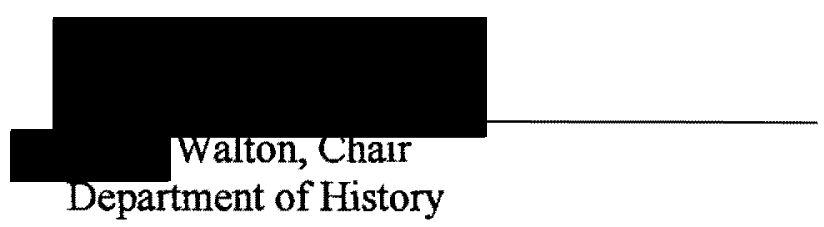




\begin{abstract}
An abstract of the thesis of Teresa L. Barnes for the Master of Arts in History presented April 23, 2004.
\end{abstract}

Title: A Nun's Life: Barking Abbey in the Late-Medieval and Early Modern Periods.

The purpose of this project is to gain an understanding of the daily lives of nuns in an English nunnery by examining a particular prominent abbey. This study also attempts to update the history of the abbey by incorporating methods and theories used by recent historians of women's monasticism, as well as recent archaeological evidence found at the abbey site. By including specific examinations of Barking Abbey's last nuns, as well as the nuns' artistic and cultural pursuits, this thesis expands the scholarship of the abbey's history into areas previously unexplored.

This thesis begins with a look at the nuns of Barking Abbey, the social status of their secular families, and how that status may have defined life in the abbey. It also looks at how Barking fit into the larger context of English women's monasticism based on the social provenance of its nuns. The analysis then turns to the nuns' daily temporal and spiritual responsibilities, focusing on the nuns' liturgical lives as well as the work required for the efficient maintenance of the house. Also covered is the relationship the abbey and its nuns had with their local 
lay community. This is followed by an examination of cultural activity at the abbey with discussion of books and manuscripts, music, singing, procession, and various other art forms. The final chapter examines the abbey's dissolution in 1539 under Henry VIII's religious reforms, including the dissolution's effect on some of the abbey's last nuns. 
A NUN'S LIFE:

BARKING ABBEY IN THE LATE-MEDIEVAL AND EARLY MODERN PERIODS

by

TERESA L. BARNES

A thesis submitted in partial fulfillment of the requirements for the degree of

\section{MASTER OF ARTS}

in

HISTORY

Portland State University

2004 


\section{DEDICATION}

For the youngest women in my family, Jerrin and Laine. Always remember you have the power to do and be anything you wish.

And, as always, for Tom. 


\section{ACKNOWLEDGMENTS}

As with anyone who has completed the arduous process of a graduate degree, I am indebted to many, for this road is certainly not traveled alone. My deepest gratitude goes to Dr. Caroline Litzenberger for her assistance and support in the research and writing of this thesis. Her scholarship and knowledge of religion in Early Modern England are impeccable, but it is her spirit and compassion that make her the remarkable person that she is. Working under her direction has truly been a joy. Thanks must also go to Allison Renwick and Dr. Jane Kristof, two extraordinary women whose love of art history and constant friendship and encouragement have enabled me to come this far. Also, thanks to Dr. John Ott for his guidance and many interesting and stimulating conversations about monasticism in the Middle Ages. By keeping the bar set high, he makes all of us better scholars.

To my parents, Terry and Lynne Barnes, I give thanks for always being proud of me and supporting my endeavors. Their love has unquestionably helped me to become the person I am today. Thanks to Charlotte Kim not only for her love and friendship, but also her passion for history which always reminds me this is a worthwhile pursuit. And finally, my most heartfelt appreciation goes to my husband and best friend, Tom Norby. There are almost no words suitable for describing how much his love, friendship, and support mean to me. Without him, none of this would have been possible. 
TABLE OF CONTENTS

PAGE

ACKNOWLEDGMENTS $\ldots \ldots \ldots \ldots \ldots \ldots \ldots \ldots \ldots \ldots \ldots \ldots$ ii

LIST OF ABBREVIATIONS $\ldots \ldots \ldots \ldots \ldots \ldots \ldots \ldots \ldots \ldots \ldots \ldots \ldots$ iv

CHAPTER

I. INTRODUCTION $\ldots \ldots \ldots \ldots \ldots \ldots \ldots \ldots \ldots \ldots$

II. THE WOMEN OF BARKING ABBEY .............. 19

III. WORK AND RESPONSIBILITY $\ldots \ldots \ldots \ldots \ldots \ldots \ldots . \ldots 48$

IV. CULTURAL ACTIVITY $\ldots \ldots \ldots \ldots \ldots \ldots \ldots \ldots$

V. THE DISSOLUTION OF BARKING ABBEY $\ldots \ldots \ldots \ldots \ldots 118$

VI. CONCLUSION ............................ 148

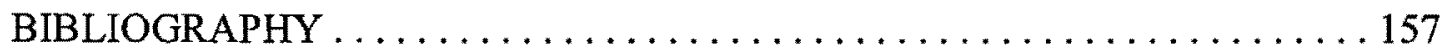

APPENDICES

A. Map of Barking Abbey from the twelfth to the fifteenth century . 169

B. Census of nuns from 1508 to $1539 \ldots \ldots \ldots \ldots \ldots \ldots \ldots \ldots$

C. Nuns present at the suppression in $1539 \ldots \ldots \ldots \ldots \ldots \ldots 171$

D. Surviving manuscripts in the library of Barking Abbey $\ldots \ldots \ldots 172$ 


\section{ABBREVIATIONS}

CPR Calendar of Patent Rolls Preserved in the Public Record Office

ERO Essex Record Office

L\&P Letters and Papers, Foreign and Domestic of the reign of Henry VIII

PRO Public Record Office, London

SR The Statutes of the Realm

VCH The Victoria History of the County of Essex 


\section{Chapter I}

\section{Introduction}

When studying monasticism in the late-Medieval and Early Modern periods, it is not difficult for the historian to find an abundance of information about male monks and their institutions. Many historians' research into monasticism up to the mid-twentieth century, particularly the influential volumes written by David Knowles in the late-1950s, have focused on male monasticism because of a supposed dearth of sources available for undertaking the same study of nuns. It was not until the late-nineteenth and early-twentieth centuries that strides began to be made in the study of women's monasticism. In 1896, Lina Eckenstein wrote Woman Under Monasticism (Cambridge), but the watershed moment came in 1922 with Eileen Power's Medieval English Nunneries (Cambridge). For the first time, Ms. Power provided a complex and comprehensive look at the life of cloistered religious women in England. These pioneering historians opened the door for interest in the study of nuns, which has grown steadily since the 1970 s and 80 s. Since then, historians such as Claire Cross, Marilyn Oliva, Roberta Gilchrist, Bruce Venarde, Jeffrey Hamburger, Jo Ann McNamara, Janet Burton, Penelope Johnson, and Sally Thompson, among others, have begun to explore more deeply the topic of female monasticism and to question some of Eckenstein's and Power's earlier assumptions. 
Though great progress has been made in the past twenty years, the study of nuns remains relatively new when compared with the study of male monks and, as with any new area of inquiry, sources are still being uncovered. Therefore, many of the histories written since the 1970s have focused on the broader picture of women's monasticism. However, particularly since the mid-1990s historians have sharpened their focus, delving even deeper into monastic life as it was experienced by women. These recent historians have begun to shine a much needed and well-deserved light on the topic, helping to illuminate the lives of religious women in Europe long left in the shadows of their male counterparts.

This thesis project began with a simple desire for a broad understanding of life inside an English nunnery in the later Middle Ages and Early Modern periods. Many questions required answers: Who lived in the convent? Were they there of their own choosing? What happened in a typical day? What did the nuns eat? Did they make art or read books? Did they have contact with the outside world? Were there responsibilities beyond prayer? What happened to them after the dissolution? To explore these questions, a single English nunnery became the focus of this study. Barking Abbey in Essex was a Benedictine house, originally of Anglo-Saxon foundation in the seventh century. A century-long interruption in its history due to probable invasion and destruction by the Danes in the late-ninth century led to a refoundation in the late-tenth century, this time by King Edgar, making Barking Abbey a house of royal origin. Barking was one of the most important female monastic institutions in England's history, and was among the last to fall under Henry VIII's 
reforms. With its rich history of more than eight hundred years, Barking Abbey seemed the perfect choice for exploration.

As Penelope Johnson has pointed out, much of the "enormous fluidity in medieval monasteries" is missed when one chooses to focus on a single institution. ${ }^{1}$ There is risk, yes, in making generalizations about the whole pie from just one slice. However, this thesis does not intend to explore life in female monastic institutions in a general sense, but rather the broad structure of daily life in a particular English nunnery. Claire Cross' study of Yorkshire nuns, Roberta Gilchrist and Marilyn Oliva's research on nuns living in the Norwich diocese, Barbara Harvey's work on Westminster Abbey, and Catherine Paxton's work on six London houses have all successfully shown that there were regional differences in both the size and wealth of nunneries and also in the social provenance of the nuns. Even Johnson's own study of twenty-six northern French monasteries bears this out. In a similar way, this study hopes to show what was particular about life at Barking Abbey by taking into account its location, size, patronage, and the family backgrounds of the women who called it home.

As mentioned above, historians have only recently begun to explore more deeply the lives of nuns. As historians' interest in women's history in general increased in the 1970s and 80 s, research on the topic of women religious emerged from the broader inquiry. In 1975, Eileen Power included a chapter on nunneries in

\footnotetext{
${ }^{1}$ Penelope D. Johnson, Equal in Monastic Profession: Religious Women in Medieval France (Chicago: University of Chicago Press, 1991), 5-6.
} 
her general history of medieval women. ${ }^{2}$ Likewise, in 1983 , Shulamith Shahar, in her The Fourth Estate: A History of Women in the Middle Ages, included a chapter on nuns. ${ }^{3}$ The information provided by these historians is general, but also represents a good foundation from which much of the subsequent and more comprehensive study has sprung. The practice of including nuns in broad analyses of women's history has continued, for historians now know they must acknowledge the importance of religion in the lives of women, particularly those in convents, as well as the roles nuns played in medieval and early-modern society. ${ }^{4}$ Then, in the 1980s several historians such as Caroline Walker Bynum, Jane Schulenburg, Rudolph Bell, and Ann Warren tried to ascertain the psychology of women religious by looking at what motivated them to make the ascetic choices they did and how society responded to them. ${ }^{5}$ Their contributions to the early historiography helped to determine and define who women religious were.

\footnotetext{
${ }^{2}$ Eileen Power, Medieval Women, ed. M. M. Postan (Cambridge: University Press, 1975).

${ }^{3}$ Shulamith Shahar, The Fourth Estate: A History of Women in the Middle Ages (New York: Methuen \& Co., Ltd., 1983).

${ }^{4}$ Chapters or sections on nuns or women and religion are found in the following: Jacqueline Eales in Women in Early Modern England 1500-1700 (London: UCL Press, Ltd, 1998); Christine Fell, Women in Anglo-Saxon England and the impact of 1066 (Bloomington, IN: Indiana University Press, 1984; Helen M. Jewell, Women in Medieval England (New York: Manchester University Press, 1996); Erika Uitz, The Legend of Good Women: The Liberation of Women in Medieval Cities (London: Moyer Bell, 1994); Suzanne Fonay Wemple, Women in Frankish Society: Marriage and the Cloister 500-900 (Philadelphia: University of Pennsylvania Press, 1981); Merry E. Wiesner, Women and Gender in Early Modern Europe (Cambridge: University Press, 1993 and 2000).

${ }^{5}$ Rudolph M. Bell, Holy Anorexia (Chicago: Univ. of Chicago Press, 1986); Carolyn W. Bynum, Holy Feast and Holy Fast: Religious Significance of Food to Medieval Women (Berkeley: Univ. of California Press, 1987); Jane T. Schulenburg, "Strict Active Enclosure and Its Effects on Female Monastic Experience (ca. 500-1200)," in John A. Nichols and Lillian T. Shank, eds., Medieval Religious Women, vol. 1, Distant Echoes (Kalamazoo, Mich.: Cistercian Publications, 1984): 51-86; Ann K. Warren, Anchorites and Their Patrons in Medieval England (Berkeley: Univ. of California Press, 1986).
} 
The 1990s saw an explosion of research and writing on women's

monasticism as historians approached the manifold aspects of monastic life using various historiographic models. In 1991, Penelope Johnson provided a gendered view of life in twenty-six French monasteries, while in the same year Sally Thompson reached similar gendered conclusions in her study of the founding of English nunneries after the Conquest. ${ }^{6}$ Three years later, Janet Burton addressed the broader question of "continuity versus change" over three hundred years of English monasticism at roughly the same time that Roberta Gilchrist and Marilyn Oliva were making archaeological and prosopographical explorations of the nunneries in the Norwich diocese. ${ }^{7}$ Barbara Harris made a social inquiry into the relationship between nunneries and aristocratic women, and Jo Ann McNamara investigated the social and cultural ramifications of living an enclosed life in Merovingian convents by analyzing two early-medieval regulae. ${ }^{8}$ In the mid-to-late 1990 s, Donald Logan also took a social approach to his research on why some women fled monastic life, while McNamara wrote a gendered history covering two millennia of nuns. Jeffrey Hamburger presented an art historical examination of nuns and their art in a German convent, Bruce Venarde compared male and female monasteries in England and France in the later-Middle Ages, and Julia Crick argued for the importance of long-

\footnotetext{
${ }^{6}$ Johnson, Equal in Monastic Profession; Sally Thompson, Women Religious: The Founding of English Nunneries after the Norman Conquest (Oxford: Clarendon Press, 1991).

${ }^{7}$ Janet Burton, Monastic and Religious Orders in Britain 1000-1300 (Cambridge: University Press, 1994); Roberta Gilchrist and Marilyn Oliva, Religious Women in Medieval East Anglia: History and Archaeology c. 1100-1540 (Norwich: Center for East Anglian Studies, University of East Anglia, 1993).

${ }^{8}$ Barbara J. Harris, "A New Look at the Reformation: Aristocratic Women and Nunneries, 14501540," Journal of British Studies 32 (April 1993): 89-113; Jo Ann Kay McNamara, The Ordeal of Community (Toronto, Ontario: Peregrina, 1993).
} 
standing patronage in maintaining the wealth and status of Anglo-Saxon nunneries. ${ }^{9}$ This flood of inquiry into all aspects of women's monastic life has only continued into the twenty-first century with historians such as Charlotte Woodford and Alison Beach, both of whom have taken a literary approach in their examinations of the writings of medieval and early-modern nuns. ${ }^{10}$

For current historians of women's monasticism, an excited anticipation continues as the prospects for uncovering even more information about the lives of nuns and their role in past societies increase each year. The historiography of this topic has evolved from the early general histories written as nuns emerged as a subject worthy of examination, to more specific publications about nuns in different periods, places, religious orders, and socio-economic backgrounds. Now that much of the groundwork has been laid, current historians have continued to narrow the focus by inquiring into specific aspects of nuns' lives, such as the art they produced, books they read or wrote, what they ate, and how they managed their households. This thesis contributes to this recent trend in the historiography by focusing on the daily lives and activities of nuns at Barking Abbey in the later-Medieval and Early Modern periods. However, significantly, this work also moves the historiographic focus from the disparate pieces of the nuns' lives, on which historians have

\footnotetext{
${ }^{9}$ Julia Crick, "The Wealth, Patronage, and Connections of Women's Houses in Late Anglo-Saxon England," Revue bénédictine 109 (1999): 251-69; Jeffrey Hamburger, Nuns as Artists: The Visual Culture of a Medieval Convent (Berkeley and Los Angeles: University of California Press, 1997); F. Donald Logan, Runaway Religious in Medieval England, c. 1240-1540 (Cambridge: University Press, 1996); Bruce L. Venarde, Women's Monasticism and Medieval Society: Nunneries in France and England, 890-1215 (Ithaca, NY: Cornell University Press, 1997).

${ }^{10}$ Alison I. Beach, "Voices from a Distant Land: Fragments of a Twelfth-Century Nuns' Letter Collection," Speculum 77 (2002): 34-55; Charlotte Woodford, Nuns as Historians in Early Modern Germany (Oxford: Clarendon Press, 2002).
} 
concentrated most recently, to reconstructing a life from those pieces, thus creating a more complete picture. It is time for historians to engage in the middle ground between the general studies, which have merely skimmed across the surface of women's monasticism, and those studies which have provided a more myopic view of aspects of female monastic life. As this study of Barking Abbey will show, this middle ground most significantly provides historians with the opportunity to experience the richness and complexity of English nuns' lives.

To avoid the pitfalls of focusing on one institution, the methodology employed for this thesis has been to work inward from a broad knowledge of women's monasticism, based on secondary source research, toward specifics about Barking Abbey through an investigation of primary and secondary sources. This thesis also compares and contrasts Barking with institutions in neighboring counties to place the abbey further within the wider context of English women's monasticism. To fill gaps in the extant evidence, this thesis periodically relies on two comparable institutions: Shaftesbury and Wilton Abbeys, which have many similarities to Barking. All three were Benedictine houses for women only. All were among the top four wealthiest female monasteries at the time of the dissolution, and ultimately, all were of royal, Anglo-Saxon foundation. ${ }^{11}$ The primary difference between the three abbeys was location; Wilton was in the neighboring county, Hertfordshire, while Shaftesbury was located in the southwestern county of Dorset. It is important to note all three abbeys' location in southern England, for it was there that the largest

\footnotetext{
${ }^{11}$ The only house larger and wealthier was Syon, a Brigittine monastery founded in 1415 that housed both male monks and nuns.
} 
and most prestigious nunneries were found due to the concentration of royalty, wealthy landowners, and merchants who were abbey patrons. In addition to comparisons with Shaftesbury and Wilton, this thesis also looks at female monastic activity in the adjacent counties of Norfolk and Suffolk, primarily through the crucial work done by Marilyn Oliva. Many of Barking's nuns originally came from these two counties; therefore, by comparing and contrasting the nunneries there with Barking, determinations may be made about why nuns from other areas were drawn to the abbey. Acknowledging the danger of gross generalizations, conclusions are nonetheless suggested periodically based explicitly on the information found at Shaftesbury, Wilton, and in the neighboring counties around Barking Abbey when sources specific to the nuns at Barking are not available.

One of the unfortunate consequences of embarking on a study of Barking Abbey is the realization early on that primary sources are woefully lacking when compared with other English nunneries. The abbey's early charters do survive as well as Barking's inclusion in William I's Domesday survey, and both provide interesting hints about the abbey's early history. Peripheral references to the abbey can also be found in various sources such as Bede's ecclesiastical history of England, bishop's registers, papal letters, and Henry VIII's letters and papers, and wills. Regrettably, however, no personal writings such as diaries or letters from the nuns have survived or been uncovered. Much of what has survived that provides any information about the nuns is contained in wills and account books from various departments in the convent. One of the most important is The Charthe longynge to 
the Office of Celeresse of the Monasterye of Barkinge (c. $15^{\text {th }}$ century), which provides an in-depth view of the responsibilities of the cellaress and also insight into what it took yearly to feed and outfit an entire monastery. ${ }^{12}$ Another document which survives is the account book from the abbey's Office of Pensions. ${ }^{13}$ This office was responsible for the distribution of the convent's general funds and was run by a committee of nuns whose names are included in each register. This thesis makes use of both of these primary sources as well as a small account book of the abbey's repairs and expenses. Fortunately for this discussion, given its focus on the end of Barking Abbey's history, all of these documents are from the fifteenth and sixteenth centuries. Lastly, the will of Barking's last abbess, Dorothy Barley, survives. Because the will was proved in 1559 and includes bequests to some of the abbey's last nuns, it provides interesting insights into the abbess' wealth as well as her relationship to former nuns twenty years after the dissolution.

Despite the fortunate circumstances which have enabled these sources to survive, much has been lost and the paucity of primary sources related to Barking Abbey hampers scholarly inquiry with the result that secondary sources are also somewhat limited. There are essentially two "recently" published studies of the

\footnotetext{
12 The Charthe (London, Bodleian Library, Cotton Julius D. viii fols. 40-7) is printed in Dugdale's Monasticon Anglicanum, vol. I, 80-3; also summarized in Power, Medieval English Nunneries, appendix I, 563-8, and discussed in Eckenstein, 372-6. An additional manuscript account from Barking's cellaress in the late 1530s is found in Public Record Office [hereafter PRO], SC 6 Hen. VIII/929.

${ }^{13}$ PRO SC 6 Hen. VIII/928.
} 
abbey, one written as a general survey and the other written more comprehensively. ${ }^{14}$ The first is E. A. Loftus and H. F. Chettle's A History of Barking Abbey, published in 1954 (Wilson \& Whitworth, Ltd.). ${ }^{15}$ It is a general overview of the abbey's history written in two parts, the first part covering the period from the foundation in the seventh century to the publication of the Domesday survey in the late-eleventh century. The second section provides information on all of the abbesses and a glimpse of daily life inside the abbey. This book provides fairly comprehensive information for some of the abbey's history, but at a scant eighty-four pages leaves many unanswered questions. The other text is a 1961 doctoral dissertation by Winifrid A. Sturman. ${ }^{16}$ Fortunately, Ms. Sturman treats her subject much more thoroughly (the dissertation runs to more than five hundred pages). Sturman's work tells a structural story of the abbey as she focuses on internal and external administration, including management of the estates, revenues, liturgical life, and the business aspects of the dissolution. Some bits and pieces of other elements of daily life can be extrapolated from her study, but most of her attention has been given to a particular, administrative slice of abbey life. She also limits her study to the period between the Conquest and the dissolution, ignoring the abbey's early history. ${ }^{17}$

\footnotetext{
${ }^{14}$ An additional history of the abbey by Walter A. Locks, Barking Abbey in the Middle Ages (London: Elliot Stock, 1913) is less than scholarly in its approach and therefore not of use to the research of this thesis.

${ }^{15}$ E. A. Loftus and H. F. Chettle, A History of Barking Abbey (Barking, Essex: Wilson \& Whitworth, Ltd., 1954).

${ }^{16}$ Winifrid M. Sturman, "Barking Abbey: A Study in its External and Internal Administration from the Conquest to the Dissolution." (Ph.D. diss., University of London, 1961).

${ }^{17}$ In chapter one, Sturman briefly covers some of the early charters in order to lay a foundation for her discussion of the abbey's estates; otherwise, the pre-Conquest period is ignored.
} 
Therefore, for two reasons it is time for a fresh look at Barking Abbey. First, as mentioned above, in the forty-three years since Sturman's dissertation (the most recent of the two studies), much work has been done in the area of female monasticism, including the application of new approaches and theories based on gender, art, writing, regionality, and prosopography previously mentioned, that may shed additional light on life in Barking Abbey. More recent historical approaches also include archaeology, and Loftus and Chettle's and Sturman's histories of Barking Abbey were not informed, as this thesis has been, by the interesting archaeological findings at the abbey site in the 1980s and 90s. Secondly, somewhere between the broadness of Loftus and Chettle and the focus of Sturman lies another story of the abbey. Rather than merely recounting for posterity the facts contained in the surviving records, this thesis analyzes the nuns and their daily life, not only in the convent but in the larger abbey community as well, in order to move the discussion beyond merely structural issues. Similar to Marilyn Oliva's and Roberta Gilchrist's treatment of nuns in the neighboring counties Norfolk and Suffolk, this study puts a human face on the Barking Abbey nuns and their lives. It takes into account many of the primary and secondary sources used by Sturman and Loftus and Chettle, but also considers Barking Abbey in light of the more recent scholarship in women's monasticism. This study, therefore, updates and illuminates four aspects of abbey life more deeply than Loftus and Chettle and more broadly than Sturman. These aspects are: the nuns' social provenance, temporal and spiritual responsibilities, cultural activities, and their fates during and after Henry VIII's suppression of their 
monastery. Through these four avenues, this thesis argues that for English religious women in the later-Medieval and Early Modern periods, monastic life was not merely a staid, oppressive cycle of prayers and toil, but a complex and dynamic human experience.

A word should be said about the apparent lack of conflict at Barking Abbey in this thesis. One only needs to read chapters two and seven of Power's Medieval English Nunneries to understand that nunneries were not exempt from the same sorts of human conflicts and squabbles that afflicted the rest of society. ${ }^{18}$ Problems in the nunneries ranged from disputes over abbess elections and behavior, interpersonal fights, and disputes with tenants and employees, to serious injunctions and admonitions from the bishop. This thesis shows that Barking Abbey was not immune to these problems given the presence of a couple instances in the twelfth and thirteenth centuries. While this small number of examples might suggest that problems were few or isolated at Barking, this study acknowledges that conflict was, as in all monasteries, an ongoing concern throughout the abbey's history due simply to the nature of so many people living in close confinement. The absence of a longer, more detailed discussion of the problems encountered by the nuns at Barking Abbey here is due to the lack of extant evidence.

Barking Abbey's history spanned more than eight centuries, and to understand the workings of daily life at the end of that history it is necessary to know

\footnotetext{
${ }^{18}$ Power, Medieval English Nunneries, 42-95 and 285-314, passim.
} 
something of the abbey's early life and traditions. ${ }^{19}$ The Benedictine Abbey of Barking was founded in Essex in approximately 666 C.E. Saint Erkenwald, who in 675 became the fourth bishop of London, established the abbey for his sister, Ethelburga, who became its first abbess and, with the Virgin Mary, the abbey's patron saint. Barking was founded as a double monastery housing both male monks and nuns, though they lived separately. The abbey quickly grew in spiritual and temporal importance, and the Venerable Bede in his Historia Ecclesiastica recounted at length the miracles performed there. In the mid-ninth century, life at the abbey halted, and concrete evidence as to why is scanty. Legend has it that the Danes invaded and sacked the monastery, burning all the inmates to death around the year 870. Raids of England's religious houses had been common occurrences since the Danes first landed in the mid-ninth century, and therefore it is probable they happened at Barking as well. In any event, the abbey was silenced and remained so for roughly a century.

In the late-tenth century, the abbey was refounded by King Edgar, who appointed as abbess Wulfilda, a nun from Wilton Abbey, purportedly as reparation for advances he had made toward her which she had resisted. From roughly that

\footnotetext{
${ }^{19}$ In addition to Loftus and Chettle and Sturman, references to portions of Barking Abbey's history can be found in several sources. The information in this discussion is derived from primary sources and the most recent secondary sources. These include: Domesday Book, vol. 32, Essex, ed. Alexander Rumble (Chichester: Phillimore, 1983); The Early Charters of Barking Abbey, trans. Cyril Hart (Colchester: Benham and Company Limited, 1953); The Venerable Bede, The Ecclesiastical History of the English Nation, trans. John Stevens, revised Lionel C. Jane (London: J. M. Dent \& Sons, Ltd., New York: E. P. Dutton \& Co., Inc., 1951); Monasticon Anglicanum, vol. I, trans. William Dugdale (London, 1693); Eileen Power, Medieval English Nunneries c. 1275 to 1535 (New York: Biblo and Tannen, 1964); The Victoria History of the County of Essex, vol. 2. Victoria History of the Counties of England, hereafter $V C H$, ed. W. Raymond Powell, H. A. Doubleday, Wm. Page, and John H. Round (Folkestone: Published for the University of London, Institute of Historical Research by Dawsons, 1977-).
} 
point forward (the specific date of the change is not known) the monastery operated as a female-only institution, known in England as a "nunnery." The abbey's history is relatively quiet in the eleventh century until the arrival of William I at the Conquest in 1066 . William confirmed his possession of the abbey by charter in the winter of that year while he was a resident there during the building of the Tower of London. By the time the abbey appeared in William's Domesday Book in the lateeleventh century, its land and livestock holdings were substantial with 78 hides (roughly 7,800 acres) in multiple counties and thirteen manors. It remained throughout its history one of the wealthiest nunneries in England; its net annual revenues of over $£ 862$ ranked it third in wealth at the time of its dissolution in 1539 . The abbey church reflected its prominence - at 337 feet in length and 100 feet in width it was larger than Rochester Cathedral-Priory and was "the most splendid of any nunnery in mediaeval England" (Appendix A). ${ }^{20}$

Though Barking's abbess was one of only four in England to hold as a baroness directly of the king (her participation as a Lord in Parliament limited only by her gender), the abbey's continued prestige owed much to the fact that it drew its inmates primarily from royalty, the aristocracy, and the upper gentry, with several of its abbesses achieving sainthood. A primary reason for Barking's upper-class and royal clientele was, as previously mentioned, no doubt its proximity to London (approximately ten miles east), the center of royal power and wealth. Among the abbesses at various points in Barking's history we find Queen Maud, wife of Henry

${ }^{20} \mathrm{VCH}, 119$. 
I, Queen Maud, wife of King Stephen, Maud, daughter of Henry II, and Maud, daughter of King John. Barking was also at one time home to the dowager Countess of Suffolk and the Countess of Oxford. The majority of its upper-gentry and aristocratic inmates were members of prominent Essex, Norfolk, and Suffolk families. Other high-profile English and Scotswomen and men were also affiliated with Barking. In the 1170s, Henry II appointed Mary Becket as abbess of Barking in reparation for the murder of her brother, Thomas Becket, the former Archbishop of Canterbury. In 1381, John of Gaunt paid the admission dowry for Elizabeth Chaucy, who became a nun at Barking and was probably a close relative (possibly even the sister) of the poet Chaucer. And in 1314 under less-favorable circumstances, Elizabeth, wife of the Scottish King, Robert Bruce, was sent by Edward II to Barking to be kept as a prisoner until she was traded for English prisoners approximately one year later. ${ }^{21}$

During its long history, the abbey faced several hardships. After the initial destruction by the Danes and its refounding in the tenth century, the abbey endured the ravages of the Black Death and multiple Thames River floods. By the turn of the fifteenth century, it had lost several hundred acres to marshes, and the nuns frequently received exemption from the king for paying taxes and providing men at arms so that they could use the resources for repairs. There was also periodic economic adversity, for though Barking Abbey was more prosperous than most English nunneries it was not immune to inflation, taxes, or the costs of litigation.

\footnotetext{
${ }^{21}$ See footnote 18 above.
} 
Despite these challenges, however, Barking Abbey flourished and, like all large abbeys, was not only a spiritual sanctuary for its inmates but a provider of important social services for its local community as well.

One of the services often provided by nunneries was the care and education of patrons' children, and Barking was no exception. In the late-Medieval period, members of the Tudor family were sent to Barking Abbey to be raised by the abbess. Later in the abbey's history, the abbess served as godmother for several children, many of whom were mentioned in her will and who came from the most important Essex families. There were other instances of the care and rearing of children dating from the abbey's earliest history, and though the numbers of children being educated or cared for at any given time at Barking may not have been large, it remained an abbey tradition for its entire history.

Charity was also an essential component of monastic life, and one aspect of this was care of the sick, especially for the poor. An indication of Barking's dedication to providing aid to the poor and infirm is found in the twelfth century when the abbess Adeliza founded a leper hospital at Ilford in Essex. This hospital was the only part of the abbey to survive the dissolution, though it was converted into an almshouse. Almsgiving was likewise a vital charitable act, and was required of the nuns by their Rule. Alms for the poor could take the form of money, though more often they were in the form of food (pittances) or clothing. Finally, the abbey contributed to the economic health of its local lay community by acting as an employer on a large scale. 
In the abbey's late history, the nuns' lives were spent fairly quietly in managing their temporal and spiritual duties. All of that ended in the 1530 s with the politics of Henry VIII, driven by his need for money and desire to dissolve England's allegiance to the Church in Rome. The surrenders of England's monastic houses to the Crown began in 1535-6 and continued until the last one had fallen in the spring of 1540. Barking Abbey was among the last, its abbess surrendering the house and all its holdings to the king's commissioner in November 1539 . In the end, this prominent spiritual institution that had managed to endure many threats over its more than eight hundred-year history could not survive the tide of political and religious reform that swept the nation.

This thesis begins by focusing directly on the women of Barking, particularly their social provenance and how their status may have affected daily life in the abbey. The analysis of Barking's last nuns provided in this chapter has heretofore not been undertaken. The next chapter focuses on the nuns' temporal and spiritual responsibilities, wherein rounds of daily prayers were mixed with the work required for the efficient maintenance of the house. The third chapter covers a new area in the study of Barking Abbey - that of cultural pursuits. This chapter examines evidence of cultural activity at the abbey with discussion of textiles, glass, painting, dramatic procession, music and singing, and finally books and manuscripts. The final chapter examines the abbey's dissolution in 1539 , including the politics which led to the surrender, the fates of some of the abbey's last nuns, and what role was left for an ex-nun in Reformation society. Though the chapters include issues of religion, 
economics, politics, class, and art, the main thrust of this project is social as we try to answer the question: What comprised a nun's life at Barking Abbey in the later Middle Ages and up to its demise in 1539 ? 


\section{Chapter II}

\section{The Women of Barking Abbey}

To learn about the daily lives of cloistered women, it is not entirely necessary to know specifically who they were. Much is already known about the daily activities of those living an enclosed religious life, particularly those within the same order, due to the fact that their lives were dictated by a Rule. Of the more than one hundred thirty nunneries in England in the late-Medieval period, more than half, including Barking Abbey, followed the Rule of Saint Benedict. ${ }^{1}$ Therefore, life in those monasteries was based on a daily series of prayers, reading, and work, which probably differed little from house to house. But within the larger scope of women's monasticism in England, exploring who the women were and the types of families they came from - in addition to what they did on a daily basis - can provide historians with information that enhances our understanding of the lives of these religious women. The purpose of this exploration, therefore, is to provide a human face for the sixteenth-century religious women at Barking Abbey. It gives historians a valuable opportunity to walk alongside the nuns, experiencing their humanity, rather than studying them as mere disconnected objects, removed from us by time and space.

\footnotetext{
${ }^{1}$ Power, Medieval English Nunneries, 1.
} 
Historians have long argued, based somewhat on Eileen Power's assertions in the early-twentieth century, that English nuns came strictly from the highest social ranks and that the monasteries were "refuges of the gently born." However, that assumption has recently been challenged by historians such as Marilyn Oliva, Catherine Paxton, and Claire Cross, who have found a different set of demographics in the nunneries they studied in London, Yorkshire, Norfolk, and Suffolk. ${ }^{3}$ Though it seems monasticism should be represented by a fairly standardized life regardless of one's social standing, it appears that nunneries, as with the rest of society, operated within a social system of "haves" and "have-nots." Some nunneries were large and wealthy for their entire history, while others were small and extremely impoverished. ${ }^{4}$ The purpose of this chapter is to investigate, to the extent that the records allow, who the nuns were in Barking Abbey's late-medieval and earlymodern history - particularly the nuns in residence at the abbey's dissolution - to determine the social make-up of the house. In researching the list of the thirty-one nuns present at the dissolution, three broad categories have emerged: (1) nuns about

\footnotetext{
${ }^{2}$ Power, Medieval English Nunneries, 4.

${ }^{3}$ See Claire Cross, "The Religious Life of Women in Sixteenth-Century Yorkshire," in Women in the Church, Studies in Church History, 27. W. J. Sheils and Diana Wood, eds. (Oxford: Basil Blackwell, 1990), 307-24; "Yorkshire Nunneries in the Early Tudor Period," in The Religious Orders in Pre-

Reformation England. James G. Clark, ed. (Woodbridge, England: The Boydell Press, 2002), 145-54; Marilyn Oliva, "Aristocracy or Meritocracy? Office-holding Patterns in Late Medieval English Nunneries," in Women in the Church, Studies in Church History, 27. W. J. Sheils and Diana Wood, eds. (Oxford: Basil Blackwell, 1990), 197-208; "Patterns of Patronage to Female monasteries in the Late Middle Ages," in The Religious Orders in Pre-Reformation England, James G. Clark, ed. (Woodbridge, England: The Boydell Press, 2002), 155-62; The Convent and the Community in Late Medieval England: Female Monasteries in the Diocese of Norwich, 1350-1540. Woodbridge: The Boydell Press, 1998; Catherine Paxton, "The Nunneries of London and its Environs in the later Middle Ages" (Ph.D. diss., Oxford University, 1992).

${ }^{4}$ In the first half of the sixteenth century and up to the dissolution, the nun population at Barking fell below thirty nuns only four times (Appendix B). Though this may not be considered large when compared with earlier monastic institutions whose populations were in the hundreds, it was considered large in early-sixteenth century England.
} 
whom we know nothing; (2) nuns about whom a small amount is known, allowing for educated guesses as to their family of origin and social standing; and (3) nuns for whom more concrete evidence exists, telling which family they belonged to and in some cases their post-dissolution fate. Examining those nuns for whom identification can be made or speculated may tell us where Barking fell within the broad social strata of English nunneries, and possibly how that position may have affected the daily lives of the nuns who called Barking home.

Why some women chose the religious life is an important factor in determining who chose it. While a true vocation for the religious life may come to mind first, historians have contended that one of the primary reasons women entered the convent was that elite women were restricted in their life choices. As Power states, "The disadvantage of rank is that so many honest occupations are not, in its eyes, honourable occupations," referring to the limited choice between marriage and the convent that elite women faced. ${ }^{5}$ Doubtless in many cases marriage was the optimal choice, but for gentlemen with unmarriageable daughters the convent was the only viable option. It was beneath the dignity of socially elite women to engage in any other occupation. However, nunneries, just like marriage partners, also often required dowries, even if it only meant the novice had to come equipped with some of her own supplies, perhaps bedding, eating utensils, etc., in order to be admitted. ${ }^{6}$

\footnotetext{
${ }^{5}$ Power, Medieval English Nunneries, 5.

${ }^{6}$ Evidence for a regular, written policy or practice regarding the requirement of dowries for entrance into a nunnery is difficult to find. However, through bishops' injunctions, entry charters, will bequests providing material support specifically for a woman to enter a nunnery, and endowments which made similar provisions, historians have long known the practice was widespread. The reason for the practice's absence from monastic records may have been a result of the Church's stern
} 
For many women in the lower ranks of society, the dowry proved to be prohibitive. Moreover, nunneries often required a new novice to have a rudimentary level of education prior to admission. Power reminds us that "the poor man's daughter would have neither the money, the opportunity, nor the leisure to acquire it."” Finally, poor women did not necessarily need the convent as an option because opportunities for occupations such as work on the family farm or in the family business, or in service with a wealthy neighbor were much more abundant and socially accepted.

However, as mentioned above, some recent historians have begun to challenge the assumption that all nunneries drew their recruits strictly from society's elite. They further argue that the principal reason why women from the lower social strata chose the convent was religious vocation and a desire to live an enclosed life devoted to God. Barbara Harris, in her study of women of the English aristocracy, asserts that aristocratic families did not prefer to place their daughters in convents because the men of the family overwhelmingly saw marriage as a more profitable opportunity to "extend their kin and client networks." Likewise, Marilyn Oliva, in

admonitions regarding the acceptance of dowries on the belief that they were a form of simony. Because of this, the Church actually prohibited them in the Council of Westminster (1175), the Council of London (1200), and the Council of Oxford (1222). However, the practice continued, for in many nunneries, particularly the smaller houses, the money and supplies a new novice could bring were necessary for the house's survival. For a discussion of dowries, see Power, Medieval English Nunneries, 17-24. See also, Kathleen Cooke, "Donors and Daughters; Shaftesbury Abbey's Benefactors, Endowments and Nuns c. 1086-1130," Anglo-Norman Studies: Proceedings of the Battle Conference 12 (1990), 44; and Paxton, 35-46.

${ }^{7}$ Power, Medieval English Nunneries, 13-14.

${ }^{8}$ Harris, 112. Harris' conclusions can be somewhat difficult to reconcile with Oliva's, primarily because Harris defines aristocratic women as the wives and daughters of knights and noblemen, which according to Oliva's social scale would make them upper gentry and not aristocracy. Harris, then, 
her extensive study of nunneries in Norfolk and Suffolk (on which this chapter frequently relies as a basis for comparing and situating Barking Abbey within the larger context of English women's monasticism), has concluded that the majority of women in those houses were not from the aristocracy, but from what she has termed the "parish gentry." She bases this on a social scale with the following classifications: (1) Titled aristocracy: royals, the baronetcy, and those with hereditary peerage titles; (2) Upper gentry: landed men who were knights, esquires, sat in the House of Commons, and filled county offices such as sheriff or escheator; (3) Lower gentry or "parish gentry:" less-well propertied men who held smaller, local offices such as constable or bailiff and sometimes steward of a religious house; (4) Urban: urban dwellers involved in trade and industry with interests in civic government; and finally, (5) Yeoman farmers: men who were substantial freeholders but generally did not hold offices. Of the 542 nuns in her study, the majority (sixty-four percent) came from the local parish gentry. ${ }^{9}$

Catherine Paxton also found, in her study of six London houses between 1370 and the dissolution, that "not many London nuns were blue-blooded," with only 2.4 percent being ascribed to the peerage. Like Oliva, she found most nuns came from gentry families, though considering the wealth of London, they were probably from the upper gentry. ${ }^{10}$ Claire Cross has also concluded the Yorkshire nunneries were populated by women from the gentry, though, like Paxton, she does

may inadvertently be concluding what most other historians of women's monasticism have, primarily that the majority of nuns came from the gentry classes.

${ }^{9}$ Oliva, "Aristocracy or Meritocracy?", 200. See also Oliva, The Convent and the Community, 7.

${ }^{10}$ Paxton, 20. 
not distinguish the lower from the upper as does Oliva. ${ }^{11}$ Each of these historians, therefore, seems to have refuted Eileen Power's assertion that monasteries were the refuge of the gently born. However, in Power's defense, she defined "gently born" nuns much more broadly than recent historians have acknowledged. Power clarifies that "To say convents were the refuge of the gently born is not to say that there was no admixture of classes within them. It included the upper class proper, the families of noble birth, and it included also the country gentry."12

Whether the motive was a true vocation or a desire to escape marriage, it is also reasonable to suggest that other factors not related to the nun's social status, for instance the size, wealth, and location of the monastery, were also important in choosing which house to enter. Additionally, kinship ties may have been important for some women who preferred to profess in a house where an aunt, sister, or even mother was already a nun. ${ }^{13}$ In the Middle Ages, it was not uncommon for entire families to enter the religious life together. ${ }^{14}$ Barking Abbey certainly had its share of family affiliations within its walls, as will be shown, with many nuns related through marriage, and many surnames repeating over the years as subsequent members of the same family took the veil. It seems so many Barking Abbey women were related, that J. E. Oxley referred to the convent as "quite a family party." 15

\footnotetext{
"Cross, "The Religious Life of Women in Sixteenth-century Yorkshire," 310-11.

${ }^{12}$ Power, Medieval English Nunneries, 6.

${ }^{13}$ Though Oliva argues this may not have been entirely true for nuns in the Norwich diocese. See The Convent and the Communtity, 61.

${ }^{14}$ I owe this point to Dr. John Ott.

15 J. E. Oxley, The Reformation in Essex to the Death of Mary (Manchester: The University Press, 1965), 58; Roseanne Michalek Desilets, "The Nuns of Tudor England: Feminine Responses to the Dissolution of the Monasteries," (Ph.D. diss., University of California at Irvine, 1995), 54.
} 
Oliva concedes that the wealth of the house may have been a determining factor.

She states, "The fact that women from high ranking families in Norfolk and Suffolk favored wealthy monasteries outside the diocese suggests a correlation between the wealth of a female monastery and the social ranks from which it drew recruits." 16 Some of the "high ranking" women to which she refers chose Barking Abbey, as will be shown later in this chapter.

Barking Abbey began as an aristocratic institution and stayed so for most of its history, admitting women further down the social scale, primarily from the wealthy merchant class, only in its later periods. ${ }^{17}$ Barking was part of the group of greater monasteries who, as Benjamin Thompson asserts, "were economically and politically strong, with seats in parliament and incomes equivalent to nobles; they were an accepted and powerful part of society.", Janet Burton adds that "the paucity of post-Conquest female foundations in the South [of England] owed not a little to the dominance of the nunneries founded in the Anglo-Saxon period, whose endowments were set early before the scramble for lands, and whose prestige must have continued to attract recruits." As a result, very few post-Conquest nunneries were ever able to match the earlier foundations in either status or wealth. ${ }^{19}$ Barking, as one of these prestigious houses, could boast of large land holdings and royalty among its abbesses, including at least two queens and two princesses. The

\footnotetext{
${ }^{16}$ Oliva, The Convent and the Community, 55.

${ }^{17}$ J. Howson, "Books and Barking Abbey," Essex Journal 1 (1966), 202; Loftus and Chettle, 27; Sturman, 407-8.

${ }^{18}$ Benjamin Thompson, "Monasteries, Society and Reform in Late Medieval England," in The Religious Orders in Pre-Reformation England. James G. Clark, ed. (Woodbridge, England: The Boydell Press, 2002), 172.

${ }^{19}$ Burton, 93, 106.
} 
aristocracy was also well represented at Barking. In the late-thirteenth and earlyfourteenth centuries, the abbess Anne de Vere came from the family of the Earls of Oxford. ${ }^{20}$ In the 1340s, Maud de Montague, sister of the Earl of Salisbury, served as abbess. ${ }^{21}$ Her sister, Isabella, succeeded her as abbess for six years, and again in 1377 we find a Montague as abbess, this time Maud and Isabella's niece. ${ }^{22}$ In the early-fifteenth century, the abbess Margaret Swynford was related by marriage to Thomas, Duke of Exeter, whose name was carved on the keystone of an abbey arch, and who also left to the abbey a number of vestments. ${ }^{23}$ Katherine de la Pole was abbess from 1433 to 1473 - the longest tenure in Barking's history. She was from the prominent de la Pole family, her uncle being William the Duke of Suffolk, and her father, Michael the Third Earl of Suffolk, who was killed at Agincourt. ${ }^{24}$ Though Katherine was Barking's last aristocratic abbess, it is important to note that her term ended only sixty-six years before the abbey's dissolution. Barking maintained its elite status long after many English nunneries had ceased to be affiliated with such prestigious families.

While information is known about some of the nuns at Barking, most of those were women who served in high offices such as abbess or prioress. Less is known

\footnotetext{
${ }^{20}$ Loftus and Chettle, 34, 36-8, 57.

${ }^{21}$ Ibid, 34, 40-1, 64.

${ }^{22}$ Ibid, $40-4$.

${ }^{23}$ Ibid, 46; Sir Alfred W. Clapham, "The Benedictine Abbey of Barking : A Sketch of its Architectural History and an Account of recent Excavations on the Site," Transactions of the Essex Archaeological Society, II (1911), 87. John of Gaunt's mistress Katherine Swynford (whom he later married) was the widow of Sir Hugh Swynford. Loftus and Chettle suggest a familial relationship between Margaret and Sir Hugh, though they do not make clear the specifics beyond stating she was his "kinswoman." Margaret's elite status is no doubt betrayed by her appointment as abbess by the newly crowned Richard II (see Loftus and Chettle, p. 42).

${ }_{24}$ Mary Erler, Women, Reading, and Piety (Cambridge: University Press, 2002), 17; Loftus and Chettle, 42, 46-8, 54, 62; Sturman, 401-2.
} 
about the hundreds of women who spent their lives within Barking's walls, perhaps holding lesser offices or none at all. For this reason we are fortunate to have a complete list of the thirty nuns who surrendered the abbey with their abbess, Dorothy Barley, in November 1539 (Appendix C). Through this list can be traced some family relationships which help to shed light on the social status of the women and the abbey at the end of its life. Not all the nuns' families can be positively identified, though speculation is possible due to the frequency of certain surnames in particular regions near Barking. It is known, as mentioned above, that in the abbey's late period, some novices from merchant families were admitted. However, these women and their families are more difficult to identify due to their absence from the surviving records. Oliva found the same phenomenon in her study of the nuns in the Norwich diocese, noting that because the sources are slanted toward the elite, historians have generally assigned unidentifiable nuns to the lower social strata, and she follows suit. ${ }^{25}$ This is perhaps an appropriate methodology; however, with an elite institution such as Barking, historians run the risk of assuming too much from silence. It cannot be automatically assumed that because a nun is absent from Barking's records she came from the lower classes, primarily because historians acknowledge that the abbey recruited from the elite for its entire history, admitting very few from the middling levels of society or lower. The percentage of women below the lower gentry at any point in Barking Abbey's history would have been very small indeed. Furthermore, before relegating to the lower social strata the nuns

\footnotetext{
${ }^{25}$ Oliva, "Aristocracy or Meritocracy?" 204.
} 
whom we have not been able to identify positively, it would be prudent to consider the possibility that those women had indeed been recorded in some of the abbey's documents, but that the documents have not survived.

Of the last nuns at Barking Abbey's surrender, there are several about whom we know only a little. These nuns were documented primarily in their relationship to abbess elections, novice professions, and pension payments after the dissolution. Margery Ballard, Margaret Cotton, Joan Drury, Agnes Horsey, Thomasina Jenney, and Ursula Wentworth had all taken part in Dorothy Barley's election as abbess in 1527 , and so had been at Barking at least twelve years at the time of the dissolution. Of these, Thomasina Jenney was already professed, and Margaret Cotton had become a novice in 1499. Elizabeth Badcock, Anne Snowe, Agnes Buknam, Margaret Bramston, and Katherine Pollard were novices professed together in 1534. Others include Elizabeth Prist, Margaret Kempe, Alice Hyde, Lucy Long, Matilda Gravell, and Margaret Greenhill, who may have been the youngest members of the house. $^{26}$

Sometimes the will of a parent or other family member is the only indication of a daughter living the religious life, as many children who were given over to the monasteries were not included in family genealogies. For instance, Thomas Badcock, whose daughter Elizabeth was among the last nuns at Barking, left in his will forty shillings to his daughter and other small gifts to various Barking nuns. $\mathrm{He}$ was steward of the abbey's manorial courts in the 1530s which may suggest he came

\footnotetext{
${ }^{26}$ Sturman, 437-8.
} 
from the lower gentry, based on Oliva's social scale. ${ }^{27}$ Similarly, Agnes Horsey was remembered in the will of her uncle, William Horsey (d. 1543), who was a canon of Exeter Cathedral. His will was proved four years after the abbey's dissolution, and in it he describes her as "late religious woman in the monastery of Barking beside London, my brother's daughter." ${ }^{28}$ While the social status of Agnes' father is unknown, her uncle William may have come from the upper gentry or had been elevated to that status upon his clerical appointment at the cathedral. ${ }^{29}$ J. H. Bettey mentions the surname Horsey as representing one of the "leading west-country landowning families," and says that its members were "well-connected [and] drawn from the upper reaches of local society." ${ }^{30}$ Given that Exeter Cathedral is situated in the western county Devonshire, it certainly seems possible that Agnes' family was connected to the Horseys to which Bettey refers.

As mentioned above, surnames can often point the historian in the right direction, and speculations may be made about possible family connections. Margaret Bramston's family has proved to be elusive, though this may be due to a spelling discrepancy. The Victoria County History of Essex lists her with the spelling above; however, Sturman spells her surname Braunston. ${ }^{31}$ The Camden Society lists a Sir John Bramston, judge, who lived in "the hundred of Chelmsford

\footnotetext{
${ }^{27}$ Sturman, 410 .

${ }^{28} \mathrm{Ibid}, 446$. William Horsey's position as a canon at Exeter Cathedral has been confirmed by the Cathedral librarian, Mr. Peter Thomas.

${ }^{29}$ I owe this point to Dr. Caroline Litzenberger.

${ }^{30}$ J. H. Bettey, "The Suppression of the Benedictine Nunnery at Shaftesbury in 1539," The Hatcher Review 4:34 (1992), 7.

${ }^{31}$ To further complicate matters, Dr. Peter Cunich, in his research of Court of Augmentations records from 1552-3, lists her as Margaret Barnesdon, underscoring the trouble of tracking the families of nuns due to misspelling or alternate spelling of surnames in early-modern England.
} 
[Essex]" in the mid-sixteenth and early-seventeenth centuries, and also his son, Thomas Bramston, Esquire, who was a knight of the shire for South Essex. ${ }^{32}$

Because of the family's location in Essex, it is possible Margaret was related to Sir John and Thomas' ancestors, though this link has not been confirmed. Similarly, no personal information exists about the nun Margaret Cotton, though Cotton was a very prominent English surname among the upper gentry. Sir Richard Cotton (d. 1556 ) is listed as a knight and comptroller of the Household under Edward VI. ${ }^{33}$ Perhaps Margaret came from a branch of that family. As well, there is no concrete evidence about Martha Fabyan, though Mary Erler has suggested that she may be related to the chronicler Robert Fabyan. Though he lists only two daughters in his will, his tomb sculpture indicates that he had six. Robert Fabyan also had two sons (Robert and Anthony), both of whom had daughters named Martha. Erler admits she cannot conclude whether either of these Marthas were nuns at Barking. ${ }^{34}$ However, Martha was not an incredibly common woman's name at that time, and if Martha was a customary Fabyan family given name, it is likely the nun at Barking was related to the chronicler. ${ }^{35}$ Though the evidence is circumstantial, her relationship to the chronicler is further likely due to geographic proximity - Robert Fabyan was from Theydon Garnon in southwest Essex, near Barking Abbey. ${ }^{36}$ Because Robert Fabyan was a member of the Draper's company and served as sheriff in the early

\footnotetext{
${ }^{32}$ The Camden Miscellany (London: The Camden Society, 1847-), 32: C32.

${ }^{33}$ Calendar of Patent Rolls Preserved in the Public Record Office, Edward VI, 1550-53 [hereafter CPR], vol. 4 (London: Published by His Majesty's Stationery Office, 1926), 391.

${ }^{34}$ Erler, 127, 193 n. 38.

${ }^{35}$ I owe this point to Dr. Caroline Litzenberger.

${ }^{36}$ Erler, 193 fn. 38.
} 
1490s, Martha too would have been considered upper-gentry. ${ }^{37}$ Lastly, Thomasina Jenney was a nun whom we know something about primarily through the offices she held at Barking. She is listed as sacrist in or by 1508 , and sometime in the eighteenth year of Henry VIII's reign succeeded Mary Tyrell as prioress and remained so until the dissolution. ${ }^{38}$ There was a Jenney family in Suffolk, among its members Sir Christopher Jenney who served as the king's sergeant-at-law and also commissioner of the peace and of the sewer. ${ }^{39}$ Sir Christopher had a sister, Thomasine, though she was not the Barking nun because she married and had a child in about $1516 .^{40}$ However, if we consider the possibility that Thomasine/Thomasina was a typical Jenney family given name, and given that Oliva has shown that prominent Norfolk and Suffolk families sent their daughters to Barking Abbey, it is possible that Thomasina was related to that upper-gentry family. There is not much to tell of Thomasina Jenney's post-dissolution fate, for she did not live long after Barking Abbey's suppression, dying in $1541 .^{41}$

There were several other nuns present at the dissolution for whom we have firmer family connections, and in some cases information about what happened to them after the dissolution. We begin with the head of the household, the last abbess

\footnotetext{
${ }^{37}$ LoveToKnow Corporation, "Robert Fabyan," n.d., $<$ http://33.1911 encyclopedia.org/F/FA/FABYAN_ROBERT.htm $>$ (8 January 2004).

${ }^{38}$ PRO SC 6 Hen. VIII/928; Loftus and Chettle, 52.

${ }^{39}$ Letters and Papers, Foreign and Domestic, of the reign of Henry VIII [hereafter L\&P], vol. 13, pt. 1, James Gairdner and R. H. Brodie, eds. (London and New York: Routledge, 1996, reprinted 2001), no. 646 (48), no. 1519 (20), no. 1519 (50).

40 "Descendants of Robert Duke," n.d., <http://freepages.genealogy.rootsweb.com/ trotter/duke.htm> (8 January 2004); "Selected Families and Individuals," n.d., $<$ http://www.gigacorp.net/ gcmeyer/pafg194.htm> (8 January 2004).

${ }^{41}$ I wish to thank Dr. Peter Cunich for this information.
} 
Dorothy Barley. Though Loftus and Chettle, in their 1954 history of the abbey, suggest Dorothy's parentage is unknown, J. Howson, in his study of the books at Barking, definitively states that she came from "a noted Hertfordshire family," and Jorge Castelli further asserts she was the sister of Sir Henry Barley of Albury, Hertfordshire. She is indicated as such in his will, in which Henry left to her a doublet and forty shillings. ${ }^{42}$ Members of the Albury Barley family were sheriffs, knights of the shire, and dons at Cambridge. ${ }^{43}$ Henry Barley was also a member of parliament just prior to his death in $1529 .{ }^{44}$ Connections with other notable uppergentry families supports Dorothy's place among them, for her maternal grandmother was Elizabeth Tyrell, who was from the prominent Tyrell family of Essex and also a relative of fellow nun Mary Tyrell. Another indication of Dorothy's overall social status is found in her will of 1556 (proved 1559), wherein she made numerous bequests of luxurious items such as a chalice and paten of parcel gilt, a gold ring, an ivory coffer with silver lock and key, a mother of pearl tablet with silver and gold images, cushions of crimson velvet, fine damask tablecloths and towels, a cross of gold set with pearls and stone, silver spoons, several gowns, several featherbeds with sheets, various other household items, and more than $£ 25$ in money. ${ }^{45}$ While it is no secret to historians of English women's monasticism that by the dissolution many nuns, particularly abbesses of wealthy houses, were living comfortably, it is

\footnotetext{
42 Jorge Castelli, "Henry Barley of Albury." n.d. $<$ http://www.tudorplace.com.ar/Bios/HenryBarley.htm> (8 January 2004); Howson, 202; Loftus and Chettle, 50.

${ }^{43}$ Loftus and Chettle, 50 .

${ }^{44}$ Castelli, "Henry Barley of Albury."

${ }^{45}$ The Will of Dorothy Barley, the last abbess, 1556, printed in Sturman, Appendix III.
} 
nonetheless a testament to Dorothy's powerful position, social provenance, and patronage connections that she was able to amass such a personal fortune. ${ }^{46}$

Among the titled aristocracy at Barking were the sisters Audrey and Winifred Mordaunt. Their relationship as blood sisters is evidence of how kinship ties within the convent continued at Barking. They were also related through marriage to their fellow nun, Dorothy Fitzlewis. ${ }^{47}$ The Mordaunts were a very old Bedfordshire family, dating back hundreds of years. Their father was John Mordaunt, First Baron of Turvey, and their mother was Elizabeth de Vere from the family of the Earls of Oxford. John was a courtier with numerous commissions beginning in 1513. At the Field of the Cloth of Gold he attended the queen, and was present when the king met with Emperor Charles V in 1520 . He was also present in Calais when Henry VIII met Francis I in 1532, and he attended Anne Boleyn's arrival at Greenwich and later, Anne of Cleves' arrival at Blackheath. He is also listed on the sheriff roll for Bedfordshire and Buckinghamshire in November $1509 .{ }^{48}$ According to the editors of The Complete Peerage, Sir John was a staunch believer in the "Old Faith," who because of his unwavering Catholic beliefs fell somewhat out of favor during Edward VI's reign. ${ }^{49}$ Because he was a member of the baronetcy and in early 1532

\footnotetext{
${ }^{46}$ Dr. Caroline Litzenberger has also raised the possibility that some of the luxurious items in Dorothy's possession at the end of her life may have been objects taken from Barking Abbey at the time of the dissolution, though this has not been confirmed. Based on Frances Dolan's assertions that former monastic ornament and objects used in worship were driven underground after the dissolution (see chapter V of this thesis), it is certainly possible to speculate that Dorothy's possession of a chalice and paten, gold cross, and tablet with holy imagery were used in her covert Catholic worship. ${ }^{47}$ Loftus and Chettle, 52; Oxley, 58 n.2.

${ }^{48}$ H. A. Doubleday and Lord Howard de Walden, eds., The Complete Peerage or a History of the House of Lords and all its Members from the Earliest Times by G.E.C., vol. 9 Moels to Nuneham (London: St. Catherine Press, 1936), 193-5.

${ }^{49} \mathrm{Ibid}, 195$ n. f.
} 
was created Lord Mordaunt, he is definitely to be considered among the titled aristocracy. His daughters Audrey and Winifred were among the youngest nuns at Barking, which according to Oxley is evident in the small pensions they received after the dissolution. ${ }^{50}$ Many younger nuns were paid small pensions, particularly if they were young enough to find a husband, for according to Henry's Act of Six Articles (1539), marriage was allowed for ex-religious who were under age twentyone when their house was suppressed. ${ }^{51}$ Winifred was approximately nineteen at the dissolution and in fact did marry a John Cheney on 23 October $1541 .^{52}$ It is not known what happened to Audrey, though according to Court of Augmentations records, she was still alive in $1553 .{ }^{53}$ She may have been even younger than Winifred and therefore was probably taken back into the home of her comfortable, aristocratic family.

Also a member of the titled aristocracy was the nun Margaret Scrope. She was the granddaughter of Henry, Fourth Baron Scrope of Bolton, Yorkshire. Her father was Robert Scrope, and Margaret was related through marriage to the Countess of Oxford. ${ }^{54}$ At Barking, Margaret served as precentrix in 1527, and was a "lady of the pension" in the mid-1530s. 55 The fact that she was sent or chose to go to Barking Abbey from Yorkshire suggests the abbey still held a certain prestige or

${ }^{50}$ The Complete Peerage, vol. 9, 194; Oxley, 238-9; Sturman 437-8.

${ }^{51}$ Joyce Youings, The Dissolution of the Monasteries (London: George Allen and Unwin Ltd., 1971), 81.

${ }^{52}$ Castelli, "Mordaunt Family," n.d.

$<$ http://www.tudorplace.com.ar/MORDAUNT.htm\#Winifred\%20MORDAUNT1 $>$ (23 December 2003).

${ }_{53}$ I wish to thank Dr. Peter Cunich for this information.

${ }^{54}$ A. I. Doyle, "Books Connected with the Vere Family and Barking Abbey," Transactions of the Essex Archaeological Society 25 (1958), 234, 241 n. 1.

${ }^{55}$ PRO SC 6 Hen. VIII/928; Doyle, 234; Loftus and Chettle, 52. 
cachet among the English aristocracy, even at this late date in its history. Sturman suggests that after the dissolution Margaret went to live with her sister, Elizabeth Peche, in Kent because she appears in Elizabeth's will which was proved in 1544. Elizabeth left "to my sister Dame Margaret Scrope sometime nun at Barking five pounds sterling." women lived together after Barking's dissolution, and furthermore, Elizabeth's will must have been written more than a year before it was proved, for according to Court of Augmentations records, Margaret died in $1543 .^{57}$ Margaret was also known to have given away one of the books previously in Barking's library, The Mirror of the Life of Christ, to an Agnes Goldwell, who may have been one of her sister's servants. $^{58}$

The following nuns for whom we have information are representatives of the upper gentry. According to Sturman, Gabrielle Shelton was one of the younger nuns still a novice at Barley's abbess election in 1527 , and then became a professed nun in $1534 .^{59}$ She was from a prominent Norfolk family, the daughter of Sir John Shelton, who is listed in Henry VIII's Letters and Papers as Steward of the Household of the King's Children, and Lady Anne Shelton, formerly Boleyn, who was the governess of Princess Mary, and Queen Anne Boleyn's aunt. ${ }^{60}$ Sir John is also mentioned at

\footnotetext{
${ }^{56}$ Sturman, 445.

${ }^{57}$ I wish to thank Dr. Peter Cunich for this information.

${ }^{58}$ David N. Bell, What Nuns Read: Books and Libraries in Medieval English Nunneries (Kalamazoo: Cistercian Publications, Inc., 1995), 107-8. Bell includes the inscription, in Latin, indicating the book beglonged to Agnes Goldwell, and that she received it from the Barking nun Margaret Scrope; Doyle, $240-1$; Erler, 46.

${ }^{59}$ Sturman, $437-8$.

${ }^{60} L \& P$, vol. 9 , index; vol. 10 , no. 307 ; vol. 11 , index.
} 
various times as a Norfolk commissioner of the peace $(1515,1538)$, commissioner of the sewer (1538), commissioner for searching and defending the coast (1539), and a "servant of Mr. Treasurer."11 With such important positions within the king's household, Gabrielle's family was clearly at the upper end of the upper gentry. After the dissolution, she returned to Norfolk to live with her family, who for their loyal service had been granted by Henry VIII the dissolved priory of Carrow near Norwich, Carrow manor, several rectories in nearby towns that had previously been appropriated to the priory, an annual pension from a vicarage, portions of tithes, and multiple advowsons of parish churches. ${ }^{62}$ In the 1555 Norwich diocese Book of Pensions Gabrielle is listed as still receiving a pension of $£ 6 .{ }^{63}$ It is interesting to consider that Sir John's family profited so handsomely from the very system that had effectively eliminated his daughter's way of life, though it is equally telling of their social standing, for very few were in a position to receive such gracious rewards from the king.

A famous Norfolk name represented among the last nuns at Barking is that of Paston. Margery Paston was the daughter of Sir William Paston of Paston Hall. Sir William had been at Cambridge in about 1495 , and by 1538 was a commissioner of the peace and of the sewer, in 1539 was a commissioner for searching and defending

\footnotetext{
${ }^{61} L \& P$, vol. 2 ; vol. 13, pt. 1, no. 646 (48), no. 1519 (20), no. 1519 (50); vol. 13, pt. 2, no. 1280 (f.55); vol. 14 , pt. 1 , no. 398 .

${ }^{62} \mathrm{Ibid}$, vol. 13, pt. 2, no. 967 (28); Sturman 444-5.

${ }^{63}$ Geoffrey Baskerville, "Married Clergy and Pensioned Religious in Norwich Diocese, 1555, Part

II," English Historical Review 48 (January 1933), 228.
} 
England's coastline, and had previously served as a sheriff of Norfolk. ${ }^{64}$ He was steward of Bromholm Priory and also served as the local representative (with Sir Roger Townesend, father of fellow nun Agnes) with the officers of Henry's Court of Augmentations as they made their visitations of local religious houses. ${ }^{65}$ The Paston family had begun more humbly, but by William's time had amassed enough land and wealth to become an important upper-gentry Norfolk family. ${ }^{66}$ Margery also returned to live with her family after the dissolution and was still there sixteen years later receiving her pension of eight marks. Apparently, she did not marry for she is listed in the Norwich Book of Pensions as having "no other living [than the eightmark pension] and is reputed a Catholic woman." ${ }^{67}$ Her father, in his will of 1554 , left her a rent of $£ 20$ annually from one of his manors. ${ }^{68}$ She apparently lived the remainder of her life in relative comfort.

As mentioned above, Sir Roger Townesend was the father of Barking nun Agnes Townesend. He began his career as a lawyer for the Paston family and later became a judge, Member of Parliament, justice of the peace, and king's sergeant. ${ }^{69}$ His son, and Agnes' brother, Roger took his turn as a commissioner of the peace, of

\footnotetext{
${ }^{64} L \& P$, vol. 14 , pt. 1 , no. 398 ; vol. 13, pt. 1 , no. 646 (48), no. 1519 (20), no. 1519 (50), The Paston Letters, Norman Davis, ed. (New York: Oxford University Press, 1983), xxix.

${ }^{65} \mathrm{~B}$. Thompson, 183; Youings, 49.

${ }^{66}$ Simon Schama, A History of Britain: At the Edge of the World? $3000 B C-A D 1603$ (New York: Hyperion, 2000), 269, 272.

${ }^{67}$ Baskerville, 208, 214; Sturman, 444. Both Baskerville and Sturman suggest that a woman's description as a "Catholic" woman meant that she was unmarried.

${ }^{68}$ Peter Cunich, "Monastic Database for England and Wales in the Sixteenth Century," 29 February $2000,<$ http:/www.hku.hk/history/cunich/monast2.html > (8 January 2004); Sturman, 444.

69 Derek Townshend, "Sir Roger Townshend," n.d.,

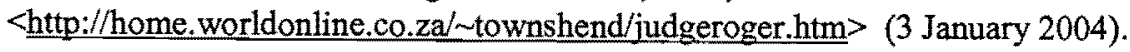


the sewer, and of searching and defending the coast for Norfolk in the late $1530 \mathrm{~s}^{70}$ Agnes' relationship with another upper-gentry family is found in 1531 when she was remembered in the will of Anne Brickys' (mother of fellow nun, Suzanna Sulyard). Lady Brickys left "to my cousin, Dame Agnes Townesend, sexton, four pairs of sheets." ${ }^{\text {71 }}$ It is not known if Agnes was a blood relative of the Sulyard family or merely had a special bond with Anne, for the term "cousin" was used somewhat loosely in the sixteenth century. ${ }^{72}$ Agnes died in 1541 only two years after her convent was suppressed. ${ }^{73}$

Mary Tyrell was a member of the Tyrells of Little Warley, an established and important Essex family. As Catherine Paxton notes, "The family claimed its descent from Sir Walter Tyrell, who had crossed from Normandy with the Conqueror. In the early-fifteenth century, John Tyrell was Treasurer to Henry VI and was one of the wealthiest landowners in Essex in 1436."74 Another relative, James Tyrell, earned the family further fame (or at least notoriety) through his supposed involvement in the murder of the princes in the Tower. ${ }^{75}$ Mary's father Sir John served as sheriff in both Essex and Hertfordshire. ${ }^{76}$ Strangely enough, Mary was related through marriage to Dr. William Petre, the commissioner who accepted the house's surrender in 1539; her sister Gertrude was his wife. ${ }^{77}$ In 1540 , Sir John in his will bequeathed

\footnotetext{
${ }^{70} L \& P$, vol. 13, pt. 1, no. 646 (48), no. 1519 (20), no. 1519 (50); vol. 14, pt. 1, no. 398.

${ }^{71}$ Sturman, 415.

${ }^{72}$ I owe this point to Dr. Caroline Litzenberger.

${ }^{73}$ I wish to thank Dr. Peter Cunich for this information.

${ }^{74}$ Paxton, 22 fn. 37.

${ }^{75}$ Ibid, 22.

${ }^{76} L \& P$, vol. 9, no. 914; Loftus and Chettle, 52; Sturman, 403, 445.

${ }^{77}$ Loftus and Chettle, 52; Sturman, 420.
} 
"to Mary my daughter sometime a nun of Barking, a ring with a sapphire that my wife hath in keeping, and a counterpoint, a feather bed, a bolster, a pillow, a pair of blankets and five marks in money." ${ }^{78}$ Because his will is dated after the abbey's dissolution, his bequests may suggest Mary had returned to her father's home. According to Dr. Peter Cunich, Mary probably died by mid- 1551 .

As mentioned above, the nun Dorothy Fitzlewis was related through marriage to her fellow inmates Audrey and Winifred Mordaunt. She was also similarly related to the Tyrell and de Vere families. ${ }^{79}$ Her father was Sir Richard Fitzlewis of West Horndon, Essex, a former sheriff in both Essex and Hertfordshire. ${ }^{80}$ We know Dorothy's father did business with the abbey, for Richard "phytzlewes" is included in the account book of the abbey's Office of Pensions as a receiver of forty shillings for "rentes resolutes." to Barking Abbey, and his widow's will, proved in 1535 , left twenty shillings each to her two daughters, nuns at Barking. Dorothy is the only Fitzlewis on the list of nuns at the dissolution; it is not known what happened to her sister mentioned in their mother's will. Perhaps she died before the dissolution, or perhaps she took advantage of Henry VIII's offer to be released from her vows during the first round of suppressions in 1535-6. Because both parents were deceased by the time of the dissolution, we may surmise that Dorothy did not return to her family as some of her

\footnotetext{
${ }^{78}$ Sturman, 445 .

${ }^{79}$ Loftus and Chettle, 52; Oxley, 58 n. 2; Sturman, 403-4.

${ }^{80}$ Loftus and Chettle, 50; Sturman quotes from the will indicating the exact amount was forty-six shillings, given to the abbess and convent at Barking for prayers, a Mass, and a dirige to be said for his soul, p. 413.

${ }^{81}$ PRO SC 6 Hen. VIIU/928.
} 
fellow nuns had, though this has not been confirmed. The Court of Augmentations records indicate Dorothy died in $1541 .^{82}$

Joan Drurye was from an important family with lines in both Norfolk and Suffolk. ${ }^{83}$ Her father was Sir William Drury of Besthorpe, Norfolk, and her uncle was Sir Robert Drury of Hawstead, Suffolk. Robert was a well-respected lawyer and courtier and was elected speaker of the House of Commons in 1495. Joan's cousin, Sir William Drury, was sheriff in Norfolk and Suffolk in $1536-7 .{ }^{84}$ She therefore appears to have been one of the nuns to which Oliva refers when claiming the elite of Norfolk and Suffolk sent their daughters to Barking Abbey instead of a local nunnery. Joan also did not live long after the dissolution, dying sometime in the mid-1540s. ${ }^{85}$

Joan's fellow nun, Suzanna Sulyard was the daughter of Sir John Sulyard, justice of the king's bench of Flemyngs in Runwell, Essex. Like Sir William Drury, his title and office designate him as firmly rooted in the upper gentry. The extent of what is known about Suzanna is found in wills. She appears in the 1531 will of her mother, Anne Brickys, wherein she was given a bed and a hanging from her mother's chamber, with an additional hanging to be given if her sister (not a nun)

\footnotetext{
${ }^{82}$ I wish to thank Dr. Peter Cunich for this information.

${ }^{83}$ Castelli, "Drury Family," n.d.,

$<$ http://www.tudorplace.com.ar/DRURY.htm\#Joan\%20DRURY1> (7 January 2004); Tom

Stevenson, "Joan Drury," 21 October 2002, <http://worldconnect.genealogy.rootsweb.com/cgibin/igm.cgi?op $=$ GET\&db=thomass\&id $=I 14031>(7$ January 2004).

${ }^{84} L \& P$, vol. 9, no. 914; vol. 14, pt. 1, no. 398 lists a Sir Wm. Drewry representing Suffolk as a "commissioner appointed to search and defend different portions of the coast," though it is not clear if this William was Joan's father or cousin; Castelli, "Drury Family, n.d., <http://www.tudorplace.com.ar/DRURY.htm\#Robert\%20DRURY\%20of\%20Hawstead\%20(Sir) $1>$ (7 January 2004).

${ }^{85}$ I wish to thank Dr. Peter Cunich for this information.
} 
predeceased her. The Sulyard family had quite a relationship with Barking for, besides the bequests made to Suzanna, her mother also left to the abbey two satin gowns for making vestments and forty shillings for prayers for her soul. She also requested burial in the abbey's Lady Chapel. Her will also singled out Dorothy Barley, who was to receive a gold tablet with images of the Trinity and Saint Anne and "a standing cup of gilt, the which I will to be in the keeping of my lady abbess now being, for term of her life, and after to the house, to remain without selling or alienation." 86 Dorothy may very well have honored this request, for, as previously mentioned, among her possessions listed in her will of 1556 (proved 1559) are a "Challes with a Patenett of parcel gylt," and a "tablet of mother of Pearle enclosing ii Images of sylver and gylt" - perhaps the standing cup of gilt and gold tablet with images of the Trinity and Saint Anne that Lady Brickys had left to Dorothy in 1531 . The only other mention of Suzanna Sulyard is twenty years after the dissolution when she appears in Dorothy Barley's will, wherein she was left a towel and a small amount of money, making Suzanna one of the oldest surviving Barking Abbey nuns. ${ }^{87}$

The remaining fourteen nuns whom we know were present at the dissolution have proven more difficult to identify. There are meager clues or possibilities which are much too speculative to be included in a scholarly discussion as conclusive in any way. For instance, the only mention of the nuns Ursula Wentworth and Margery

\footnotetext{
${ }^{86}$ Sturman, 414-5.

${ }^{87}$ The Will of Dorothy Barley, the last abbess, 1556, printed in Sturman, 531; Sturman, 443; See also chapter five of this thesis.
} 
Ballard is their inclusion in post-dissolution pension records and in Dorothy Barley's will. To Margery she bequeathed a pair of flaxen sheets, a diaper towel, "a fyne Raylle," and a small amount of money. To Ursula she left a mother of pearl tablet with two silver and gilt images. ${ }^{88}$ Though there was a prominent Wentworth family among the Suffolk upper gentry, including a Lord Wentworth who was appointed in February 1539 as commissioner to search and defend portions of England's coastline, a positive connection between Ursula and any specific branch of that family has not been found. ${ }^{89}$ The search for a Ballard family has been even less fruitful. Similarly, an Anne Buknam has been identified as a gentlewoman in the court of Elizabeth of York, but her family's possible relation to the Barking nun Agnes Buknam is not known. ${ }^{90}$ The nun Margaret Kempe has likewise not been positively identified, though the name Kempe was not uncommon near Barking Abbey and elsewhere. The famously pious woman, Margery Kempe (c. 1373 - c. 1440) came from Norfolk, and there was a Thomas Kempe who served as Bishop of London in the mid-fifteenth century. There was also a Sir William Kempe from Kent in the late-fifteenth and early-sixteenth centuries, but asserting any correlation between these and the Barking nun would be a foolish guess. Sturman asserts that Alice Hyde was among the youngest women at Barking, and Oxley likewise argues

\footnotetext{
${ }^{88}$ The Will of Dorothy Barley, the last abbess, 1556, printed in Sturman, 531; See also chapter five of this thesis.

${ }^{89} L \& P$, vol. 14 , pt. 1 , no. 398.

${ }^{90}$ Richard III Society, American Branch, "Privy Purse Expenses of Elizabeth of York: Wardrobe Accounts of Edward IV, Part 16.2: Index and Notes for Privy Purse Expenses, Baybroke through Christenings," 12 April 1996, <http://www.r3.org/bookcase/wardrobe/purnote2.html> (9 January 2004).
} 
that her small pension is an indicator of that status - she received an annual stipend of just over thirty-three shillings. ${ }^{91}$ Beyond that, nothing is known of her.

Issues with variations in the spelling of English surnames in the lateMedieval and Early Modern periods only serve to complicate matters. In trying to find Elizabeth Banbrik, we may be forced to consider Banbrigg, Banbrook, or even Banbridge. Likewise, Margaret Grenehyll might be from the family Grenehill or Greenhill, and Elizabeth Prist's name may have been spelled Prest, Preston, or Pryst. Other nuns' surnames are much too common, such as Long, Wyott (Wyatt), or Snowe, for positive identification with Barking Abbey without first having at least a small clue as to where to begin the search. As Catherine Paxton so eloquently puts it, "Names alone are no more than dry bones." ${ }^{.92}$ Unfortunately, until more evidence comes to light, the remainder of the Barking Abbey nuns present at the dissolution will have to rest in utter obscurity.

\section{CONCLUSION}

Of the broad categories described in the introduction to this chapter, our research has shown that among the last thirty-one nuns at Barking's dissolution we can make no conclusions about the families or social standing of 45 percent of them; we have found enough information to make an educated guess about 19 percent; and we can positively place 36 percent. As Oliva did with the unknown nuns in Norwich diocese, we could ascribe the undocumented women to the lower classes. Oliva was

\footnotetext{
${ }^{91}$ Oxley, 239; Sturman 437-9.

${ }^{92}$ Paxton, 16.
} 
able to make that conclusion because sources for the elite women in her study are plentiful. Because the elite are easily documented, those women not appearing in the sources are safely, Oliva believes, relegated to the lower classes. However, the sheer lack of source materials across all levels of social rank at Barking Abbey makes it difficult to come to the same conclusion. Additionally, since Barking was generally an elite institution for its entire history, we are reluctant to conclude with any certainty that all 45 percent of the unknown nuns came from the lower classes. It might make more sense to apply loosely the ratios listed below for the identified nuns to the group for which we lack adequate information. However, though lack of surviving documents makes Barking Abbey nuns a challenging subject to research, we have been fortunate to identify, either concretely or through strong speculation, seventeen nuns, or 55 percent of those who were still at the abbey in November 1539 when the house was surrendered. Of these seventeen women, 65 percent (eleven nuns) are solid, positive identifications. The families and social status of the remaining six nuns have been hypothesized based on available evidence and the occurrence of surnames in locations near Barking Abbey or Essex.

With Oliva's social scale as the benchmark, our findings indicate that of the eleven clearly identifiable nuns, three ( 27 percent) came from the titled aristocracy, and eight ( 73 percent) came from the upper gentry. None came from lower gentry, urban or yeoman farmer families. Paxton's research on London nunneries, which indicates those convents were primarily populated with members from urban families, could help to explain why none of them appeared at Barking. Barking 
Abbey, though in the London diocese, was a more rural institution than those houses in London proper and therefore may have appealed less to urban families. And Power's assertions regarding the poorer (in this case, the yeoman farmer) families' inability to afford monastic dowries or properly educate their daughters for entrance into a nunnery appear true in Barking Abbey's case, for we find none of them represented among the identifiable women. The lower or "parish gentry" is the wild card in our study and may possibly be represented in the group of unknown nuns. While the upper gentry and even a few aristocrats were represented to a very small degree in the houses studied by Oliva, Cross, and Paxton, the majority of nuns were from the lower ranks of society such as the "parish gentry" and the urbanites. On the other hand, Barking Abbey's majority of nuns came from the upper gentry, with a larger percentage of its remaining nuns coming from the titled aristocracy. Contrary to these historians' findings elsewhere in England, it appears from our sampling of eleven nuns that Barking Abbey did maintain its position as one of the most esteemed nunneries in England's history and a preserve of society's elite.

But what do these conclusions tell us about the lives of nuns at Barking Abbey? How would being an elite institution have affected the quality of the nuns' lives? As the injunctions made periodically in Barking's history by bishops who admonished the nuns for luxurious or lax behavior can attest, elite nuns in a wealthy abbey probably lived as comfortably as secular women of equal standing, and most certainly better than women in smaller, poorer nunneries. Also, Barking's abbess lived in a separate household staffed with her own servants, which is something only 
the head of an affluent house could afford to do. The first-rate contents and number of personal servants described in Dorothy Barley's will give an indication of just how comfortable the lifestyle of a powerful abbess could be. The king, as patron, often sent favorites to Barking Abbey to retire. These "corrodians" would have been from the aristocracy or upper gentry, and they would have brought their customary standard of living with them. ${ }^{93}$ Because the nuns were generally from this peer group, there must have been times when the comfort of the corrodians' lives crept into that of the nuns. In poorer nunneries, the opportunity for this type of commingling would have been essentially nonexistent. Relations with other patrons could also be influential on the nuns' lives because the money and material support sent by those elite families allowed the nuns (their daughters, nieces, widows) to live in a manner perhaps similar to how they would have lived in the secular world. As Janet Burton points out, "The patronage of religious houses is a good indicator of cultural identity." 94 For elite patrons, endowing a monastery was a status symbol, and a decrepit standard of living inside the convent would have reflected badly on those who supported it. On a more mundane daily basis, the nuns' diets at Barking were also better and more varied than at other houses, which again is something only the richer nunneries could afford. ${ }^{95}$ Finally, from a purely practical standpoint, being in a wealthy nunnery meant survival for a short time in the England of the 1530s.

Because the deciding factors for which houses would be suppressed in 1535-6 were a

\footnotetext{
${ }^{93}$ A "corrody" was originally a term for a monk's daily allowance, but later was used to describe any sort of pension or payment made or granted by a monastery. These payments could be in money or in kind. See Oxley, The Reformation in Essex, p. 52.

${ }_{95}^{94}$ Burton, 35.

${ }^{95}$ See discussion about the nuns' diets in chapter three of this thesis.
} 
population of fewer than twelve nuns and annual revenues under $£ 200$, Barking Abbey, with 31 nuns and net annual revenues in excess of $£ 800$, escaped the first round of dissolutions. The abbey's wealth and prominence had enabled its nuns to live their chosen life for four more years. 


\section{Chapter III}

\section{Work and Responsibility}

Historians have generally regarded the late-Medieval period as a time when women of noble, aristocratic, or royal birth had two primary "occupational" options: marriage or the convent. After the rise of towns and into the Early Modern period, work at a craft or in a family business was an option for women of the middling sort, but these opportunities remained somewhat elusive to elite women. The primary employment for women of the highest social strata was to provide heirs, preferably male, in order to continue their husband's family line. Any other "job" would have been considered beneath them. For women of the knight or gentry classes, life choices hinged on their father's ability to raise a dowry large enough to enable them to marry. If only a small dowry could be raised, a young woman would most likely find herself "married" to the church and in a life spent behind cloister walls. But where opportunities to learn, work, and achieve were concerned, this option may have been the best of all, for it was inside the nunnery where women gained a level of education, authority, and responsibility that was unmatched by most of their secular sisters.

Lina Eckenstein and Eileen Power, who were pioneers in writing about women's monasticism, both recognized the benefits and administrative opportunities 
that convent life provided for single women. ${ }^{1}$ As well, Merry Wiesner has argued that personal empowerment could be found in the convent, and that abbesses were some of the most independent and powerful women in late-medieval and earlymodern Europe. ${ }^{2}$ In their study on religious women in Norfolk and Suffolk, Roberta Gilchrist and Marilyn Oliva found that in the running of their communities, nuns enjoyed more independence than secular women. ${ }^{3}$ Oliva has further pointed out that nuns from the parish gentry and yeoman farmer families reflected well on their families from a social standpoint because of the education they received and the offices they were therefore able to hold. Those opportunities did not exist for them outside convent walls, and so were considered "a step up" for them and their families. ${ }^{4}$ Nuns ultimately had to answer to the authority of the Church, but legal and economic restraints were far more restrictive of secular women who engaged in trade or business administration. ${ }^{5}$ Shulamith Shahar states that at all levels of society, "the legal status and real rights" enjoyed by single women and widows (those most likely to take the veil) differed from their married sisters. ${ }^{6}$ She further argues that in addition to these legal freedoms, many women joined the convent because they could escape male domination, become more educated, and if they held office, could "wield broad authority and exercise their talents as leaders and

\footnotetext{
${ }^{1}$ Lina Eckenstein, Woman under Monasticism: Chapters on Saint-Lore and Convent Life between A.D. 500 and A.D. 1500 (Cambridge, 1896); Eileen Power, Medieval English Nunneries c. 1275-1535 (Cambridge, 1922).

${ }^{2}$ Wiesner, chapter six.

${ }^{3}$ Gilchrist and Oliva, 17.

${ }^{4}$ Marilyn Oliva, "Patterns of Patronage," 161.

${ }^{5} \mathrm{Ibid}$; Gilchrist and Oliva, 17.

${ }^{6}$ Shahar, 5.
} 
organizers."7 While it is foolish to believe, as Nancy Bradley Warren points out, that nuns completely escaped male domination (the Catholic Church was still an extremely patriarchal institution after all), they nevertheless achieved a level of independence in handling their own affairs that put them on a par with women of femme sole status. ${ }^{8}$

However, though independence and freedom from male control may have been the reasons why some women entered the convent, this thesis argues that many women undoubtedly did so because they had a particular vocation for the religious life and that, as far as the nuns were concerned, opportunities for responsibility and authority were merely byproducts of that vocation. ${ }^{9}$ While true religious calling can be difficult to determine in the absence of testimony from the nuns themselves, historians of women's monasticism often point to bishops' registers and visitations, which indicate that in the majority of monasteries, nuns were consistently performing their spiritual duties and living up to the pious expectations society had of them. This adherence to the religious life is seen by historians as proof of dedication and thus, vocation. Further, Skinner and Venarde used entry charters in their studies of French and English nuns, which indicated not only life status and gifts to the convent, but oftentimes personal statements of vocation. Admittedly,

\footnotetext{
${ }^{7}$ Shahar, 8 ,

${ }^{8}$ Nancy Bradley Warren, Spiritual Economies: Female Monasticism in Later Medieval England (Philadelphia: University of Pennsylvania Press, 2001), 63.

"Burton, 7, 87-91; Cross "The Religious Life of Women in Sixteenth-Century Yorkshire," 308; Gilchrist and Oliva, 82; Johnson, 18; Oliva, The Convent and the Community, 74, 211; Paxton, 56-61; Mary Skinner, "Benedictine Life for Women in Central France, 850-1100: A Feminist Revival," in Medieval Religious Women, John A. Nichols and Lillian Thomas Shank, eds., vol. 1, Distant Echoes (Kalamazoo, MI: Cistercian Publications Inc., 1984), 96-100; Venarde, xiii, 101-2, 125-6.
} 
proof of vocation would be hard to come by in the case of child oblates, most of whom were sent to convents by their families, most likely without a personal vocation at such a tender age. However, for women who entered convent life as adults, particularly in the later Middle Ages and Early Modern periods when alternate outlets for pious expression existed such as lay sister, hospital sister, or anchoress, the choice to take religious vows and live enclosed in a community of nuns must have been, in most cases, based on true vocation and a conscious desire to live a very specific type of religious life. The nuns' vocation and dedication meant that many of the responsibilities they had over themselves and others, and the authority they wielded, came to them as a matter of course, for the community had to be sustained if they wanted to pursue a life devoted to Christ. One could not exist without the other. As Power observes, for nuns a monastery was [primarily] a house of prayer, but it was also

From a social point of view, a community of human beings, who require to be fed and clothed; it is often a landowner on a large scale; it maintains a more or less elaborate household of servants and dependents; it runs a home farm; it buys and sells and keeps accounts. The nun must perforce combine the functions of Martha and Mary. ${ }^{10}$

Though the nuns invariably had assistance from outside the house, it was they themselves who were primarily responsible for the daily administration of their community. A cursory glance at the offices held and responsibilities in the nunnery remind us that at the very least these women had to be capable. At Barking Abbey

\footnotetext{
${ }^{10}$ Power, Medieval English Nunneries, 131.
} 
we find that the nuns who lived and prayed in that monastery were, out of practical necessity, masterful at combining the active and contemplative life.

The hierarchy of the monastic corporation basically consisted of two levels: those who oversaw the institution's administration such as the abbess and prioress, and those women working under them called "obedientiaries" with specific functions (or "obediences") such as sacrist, cellaress, and infirmaress." These were the women responsible for the efficient management of the household on a day-to-day basis. Power argued that one of the chief reasons why so many nunneries were impoverished was simply because nuns were inept managers. ${ }^{12}$ This argument, when coupled with her primary assertion that only elite women entered convents, seems to suggest that those women who entered the nunnery did so with no training or skills whatsoever in managing households or accounts. Of course this was not true, for many a great lady held at least some responsibility for overseeing the servants, and therefore aspects of the daily management of her own house. ${ }^{13}$ And especially since many elite women who entered the convent did so as widows, they certainly would have arrived with some household administrative experience, or at the very least a level of maturity gained through time spent as a wife and mother. ${ }^{14}$

\footnotetext{
"The obedientiary system used at Barking Abbey was exactly the same as the system used in male monasteries. For a discussion of this system in male houses, see Burton, Monastic and Religious Orders, 249-52.

${ }_{12}^{12}$ Power, Medieval English Nunneries, 203-28.

${ }^{13}$ C. M. Woolgar, The Great Household in Late Medieval England (New Haven: Yale University Press, 1999), 202-3.

${ }^{14}$ Catherine Paxton has shown that there was also no correlation between the social status of nuns and their fulfillment of their religious duties. In other words, elite women were not more inclined toward religious laxity. See "The Nunneries of London," 14.
} 
Though lack of managerial acumen was no doubt true for some nuns, more recent scholarship has shown that the majority of nunneries were well managed. Marilyn Oliva found evidence for "gross mismanagement" lacking in her study of nunneries in the diocese of Norwich. ${ }^{15}$ Nancy Bradley Warren, in her analysis of Brigittines and Minoresses in late-medieval England, also found that the nuns were very effective in managing their households and maintaining the business relationships with patrons and members of their communities that were necessary for ensuring their long-term survival. ${ }^{16}$ In French nunneries, too, Penelope Johnson found the argument that nuns brought financial woes upon themselves unwarranted. Moreover, she suggests the whole idea of the nuns' ineptitude may have been "helped along by the propaganda of those greedily eyeing their assets." even the best managed nunneries suffered setbacks due to the ravages of nature (fire, flood, and pestilence), taxes, or economic downturns. And any type of setback would have, at the very least, had a negative effect on the house's founders and patrons, thereby threatening future donations and support (let alone endangering the stability of the house for the nuns themselves). ${ }^{18}$ Therefore, creating additional problems by mismanaging convent resources would have been ill-advised for any group of nuns, and it would be foolish to suggest they were not fully aware of this. It is essential to keep in mind, as no doubt the nuns did, the purely practical reason for sensible and effective management: without it, the house would fall into ruin and the

\footnotetext{
${ }^{15}$ Oliva, The Convent and the Community, 101.

${ }^{16} \mathrm{~N}$. Warren, chapter three.

${ }^{17}$ Johnson, 225.

${ }^{18}$ Johnson; B. Thompson, 173.
} 
nuns' way of life would disintegrate. The abbess Petronilla summed up nicely the reason for good management, to which the vast majority of convent officers probably subscribed

Often putting aside the glory of reading and prayers, we turn to management of temporal goods for the advantage of our successors, which indeed we do for this reason: that when we are sleeping in our tombs, we may be helped by their prayers before God. ${ }^{19}$

In abbeys such as Barking, the chief executive officer was the abbess.

Among the household's offices there was no higher authority. The Rule of Saint

Benedict required that

An abbasse that may be hable $\&$ worthy to take vppon hir the Rule \& gouernance of a monastery or congregacion / must all wey call to hir rememberaunce \& consydre the name of the dignite that she is called by / and labour effectually that hir dedes be accordinge to hir name / and in nothinge contrary to the dignite that she is called / for she occupieth the place of almighty god: in the monastery ${ }^{20}$

As the leader and spiritual mother, her position was the most important in the institution, and her job required a high level of skill in organization and administration. At Barking Abbey, which held more than 1,000 acres and manors in several counties, the abbess' rights and responsibilities were so extensive that had she been male, she would have been a Lord in Parliament, as her brethren abbots were. $^{21}$ As a significant landholder, she was one of only four English abbesses, along with those at Shaftesbury, Wilton, and St. Mary's Winchester, to hold baronial

\footnotetext{
${ }^{19}$ Venarde, 118.

${ }^{20}$ Here begynneth the Rule of seynt Benet: Richard Fox's translation of the Benedictine Rule for women, 1517, printed in Female Monastic Life in Early Tudor England, Barry Collett, ed. (Burlington, VT: Ashgate Publishing, 2002), 90; Sturman, 430.

${ }^{21}$ Loftus and Chettle, 55; Power, Medieval English Nunneries, 43-5.
} 
status. ${ }^{22}$ With such status and responsibilities, the election of a new abbess after the death or resignation of her predecessor was a formal and serious affair. To be qualified for the job, one had to be of legitimate birth, good reputation, at least twenty-one years of age, and if entering a Cistercian order, age thirty. ${ }^{23}$

At Barking, the abbess was elected under regulations that took their authority from the Fourth Lateran Council in 1215. Under these regulations, a group of nuns petitioned the king (their patron) for license to vote or congé d'élire for a new abbess. Once the license had been granted, a feast day was selected when the election would take place. Four "scrutineers" were chosen from among the nuns, who in turn appointed the nominees for office. All nuns then voted (even those sick and infirm) for the nominee of their choice, and a new abbess was elected. ${ }^{24}$ Power has argued that many times the abbess was chosen because of her relatively high social standing in the community. She points to Barking, which had "a long line of well-born abbesses, including three queens and two princesses." Katherine de la Pole, who was daughter of the Earl of Suffolk and abbess at Barking for forty years in the fifteenth century, became abbess at age twenty-two, which Power sees as evidence that her family connections were probably highly influential in her election. ${ }^{25}$ Marilyn Oliva has contested this assumption, however, in her study of

\footnotetext{
${ }^{22}$ Eckenstein, 365; Power, Medieval English Nunneries, 185; N. Warren, 61.

${ }^{23}$ Oliva, The Convent and the Community, 77; Power, Medieval English Nunneries, 45.

${ }^{24}$ Loftus and Chettle, 55.

${ }^{25}$ Power, Medieval English Nunneries, 42. She argues this for Katherine de la Pole because to be elected abbess, one had to be at least twenty-one years of age. Therefore, to have been elected at age twenty-two suggests, for Power, some level of familial influence. Sally Thompson echoes this in her study of twelfth and early-thirteenth century nunneries in England, suggesting that family influence
} 
542 nuns in the diocese of Norwich between 1350 and 1540 . She has found that among this group, the evidence clearly points to the fact that women were elected abbess primarily based on merit and not social standing. In this diocese, Oliva found that though the nuns' secular families ranged from titled aristocracy down to yeoman farmers, the vast majority of office holders were from the middle demographic, that of the parish gentry. ${ }^{26}$ Oliva's findings would certainly be more in keeping with the spirit of chapter sixty-four of Benedict's Rule, which treats the election of the abbess and requires that she be chosen based on her doctrine and wisdom, and the merits of her life though she be lowest in degree of the entire convent. ${ }^{27}$ However, the reality of the situation for most nunneries probably lies somewhere between these two arguments, and the wealth and size of the house must be considered when discussing the pedigree of the women inside it. It is reasonable to assume that in most cases both merit and social standing played a part in abbess elections. Barking Abbey, which did have a long history of elite women who served as abbess, also had abbesses and obedientiaries who were not from titled aristocracy, showing that for at least some of its nuns competency may have been the overriding factor in their election to office.

The abbess' competence was mainly exhibited in secular matters, for the majority of her duties revolved around the legal and financial responsibilities of the

could have been a factor in at least some abbess and prioress elections, though she concedes it is difficult to know for sure how much because in the earlier period the nuns were known only by their first name, making connection to a particular family problematic (see Women Religious, 186).

${ }^{26}$ Marilyn Oliva, "Aristocracy or Meritocracy?", 197-208.

${ }^{27}$ See Fox's translation printed in Collet, 157. 
estate. A chief financial responsibility was the administration of the general funds of the house. These funds were derived from leases of demesne lands from the abbey's fifteen manors, the lease of Barking mill, rents in Barking, and collection of taxes. As well, the fund received payments in kind of grain, produce, wood, and hay from various manors. ${ }^{28}$ These goods and cash were used by the abbess' obedentiaries (the office holders subordinate to her discussed below) for the daily management of the house. Legally, the abbess was required to provide the king with men at arms in times of war, hold manorial courts, and maintain a prison. She was also required to handle any litigation in which the abbey found itself, and with multiple tenants, the opportunities (as with most monasteries) were not infrequent. ${ }^{29}$ Lastly, the abbess supervised her stewards in the abbey's manor courts. These courts happened with such frequency (usually every three weeks) and potential complexity, that after the thirteenth century the stewards were generally trained as lawyers. ${ }^{30}$ Frequent dealings with the world outside convent walls also meant the abbess had to be respected in the world of men. It is telling that when a contemporary chronicler wrote of the abbess Euphemia of Wherwell monastery he praised "that she seemed to have the spirit of a man rather than of a woman."31

\footnotetext{
${ }^{28}$ PRO E 101/458/7; Sturman, 227.

${ }^{29}$ Loftus and Chettle, 53. Their book, A History of Barking Abbey, contains several instances of abbesses involved in litigation. Two such instances are the legal activities of abbess Christiana de Valognes and abbess Mabel of Bosham. Christiana was only abbess for thirteen years, but spent the first half of her tenure involved in six different law suits. Mabel later served as abbess for thirty-two years and was plagued by litigation for twenty-eight of those years (pp. 30-2).

${ }^{30}$ Ibid, 53.

${ }^{31}$ Power, Medieval English Nunneries, 89-90.
} 
In addition to her responsibility for the estate at large, the abbess also saw to the administration of her own private house, which was separate from the other nuns. Her household had its own kitchen and cook, as well as several personal servants. ${ }^{32}$ Barking's last abbess left in her will money and goods to no less that six personal servants. ${ }^{33}$ A separate residence sometimes meant abuses of the privilege, and in 1279, Archbishop Peckham laid an injunction on Barking's abbess urging her not to spend too much time in her own apartments, and reminding her to dine occasionally with her sisters in the convent - a sure indication this was not her regular practice. ${ }^{34}$ The house was not a perquisite merely for the abbess' own enjoyment. Sturman points out that the children mentioned in Barking's records as wards of the abbey were probably being raised by the abbess in her household. ${ }^{35}$ Money payments were recorded as received by the abbey for the board and education of young children in both the early-fifteenth and early-sixteenth centuries; Edmund and Jasper Tudor, as small boys aged five and six, were placed in the custody of the abbess of Barking from about 1437 to 1440 , and Sir John Stanley directed in his will of 1528 that his son and heir be placed in the abbess's care at Barking until he reached age twelve. Sir John paid $£ 15$ annually for this service, and included an additional $£ 20$ per year to cover any expenses incurred by the boy and his servants. ${ }^{36}$ With an eight hundred-year history of patronage and relationships with the elite of Essex and

\footnotetext{
${ }^{32}$ Sturman, 266.

${ }^{33}$ The Will of Dorothy Barley, the last abbess, 1556, printed in Sturman, appendix III.

${ }^{34}$ The Register of Archbishop Johannis Peckham, (Rolls series) vol. 1, printed in VCH, 81-86; Loftus and Chettle, 35; Power, Medieval English Nunneries, 60; VCH, 117.

${ }^{35}$ Sturman, 267.

${ }^{36}$ Loftus and Chettle, $47,50$.
} 
neighboring counties, we must assume those were not the only instances of families trusting the abbess with their children, particularly when Bede, in the abbey's very early history, recounted the story of a boy "who by reason of his infant age, was bred up among the virgins dedicated to God [at Barking Abbey], and there to pursue his studies, ${ }^{, 37}$ Serving as a guardian of children was just another aspect of the charitable duties with which the abbess was charged. Clearly, her residence served multifaceted purposes and was most likely the abbey's administrative center.

With so much riding on her shoulders, an abbess' life could be problematic if she periodically failed in her duties. As mentioned above, there were instances when the abbess was admonished by church officials for poor performance. In the latetwelfth century, Barking's abbess Adelidis was strongly reprimanded by Archbishop Theobald because of her "notorious familiarity and cohabitation" with the abbey's administrator, Hugh of Barking. ${ }^{38}$ Other complaints against an abbess were frequently generated by the nuns inside the house, who accused their superior of such crimes as favoritism, autocratic leadership, mishandling of convent funds, dressing too richly, and receiving inappropriate gifts. ${ }^{39}$ However, we may expect these criticisms when remembering the nature of so many people living together in forced confinement. There was bound to be infighting and personal problems to be overcome from time to time; the abbess and her nuns were human after all. It is unfortunate that because of the nature of the historical record, historians generally

\footnotetext{
${ }^{37}$ Bede, Ecclesiastical History, 176-77.

${ }^{38}$ The Letters of John of Salisbury, vol. 1, The Early Letters (1153-1161), W. J. Millor and H. E. Butler, eds., revised by C. N. L. Brooke (Oxford: Clarendon Press, 1986), 111.

${ }^{39}$ Power, Medieval English Nunneries, chapter two, especially beginning on p. 80.
} 
only learn about those few whose misdeeds were recorded by visiting authorities.

But in this case it is encouraging that in the surviving records there are relatively few instances, and therefore we may suppose bad behavior in the convent was not the order of the day. The abbess had a huge level of responsibility somewhat akin to a woman running a small company in the twenty-first century, so she had to be mindful of her duties and respectful of her sisters for the house to run smoothly. It is understandable that problems arose occasionally and sometimes became even larger issues for those few abbesses ill-equipped to handle them.

In great independent monasteries such as Barking, the prioress was handpicked by the abbess and second to her in executive importance. ${ }^{40}$ While the abbess was somewhat removed and busy with the secular, financial, and legal matters of the convent, the prioress saw to the day-to-day administration of the house. According to Winifrid Sturman, the prioress held great authority and her primary responsibility was "to meyntene Religion" (seeing that the daily devotions were properly kept) and discipline among the nuns. ${ }^{41}$ Also, more generally, she oversaw the obedientiaries who performed functions such as laundry, procurement of supplies, cooking, care of vestments, and nursing of the sick. Though each obedientiary was essentially in charge of her own department and revenues, she still answered to the prioress. Barking Abbey was large enough to have the additional offices of subprioress and third prioress, both of whom assisted the prioress. These three women held

\footnotetext{
${ }^{40}$ Eckenstein, 370; In smaller monasteries dependent on a great abbey, the prioress served as head of the house. See Essex Record Office, hereafter ERO, publication no. 41, Essex Monasteries (Chelmsford: Essex City Council and ERO, 1964) 17.

${ }^{41}$ Essex Monasteries (ERO, 1964), 17; Sturman, 270.
} 
important positions as human resource managers, for it was due to their organizational and people skills that the nuns' daily routine of praying and working maintained a disciplined balance. Moreover, they were co-administrators in the abbey's Office of Pensions, which received revenues from spiritualities and rents of assize that they in turn distributed to the nuns and priests on the anniversaries of important abbey patrons. They also directed funds toward the wages of the priests responsible for keeping the shrine of Ethelburga, Barking's first abbess and patron saint. $^{42}$

Below the abbess and prioress, there were several obedientiaries charged with completing the various tasks necessary to run the house. On some days, primarily great feast days, there was little time for the nuns to see to the daily chores because they were involved in the divine office, mass, chant, procession, and vocal prayer for the entire day, taking only one break for a meal. ${ }^{43}$ However, to get all the necessary work completed, Barking Abbey divided its members into "ladies of the household" and "ladies of the choir," with the choir ladies having more choral duties such as singing diriges for patrons. As the title implies, the household ladies saw to the daily tasks of household upkeep while the choir ladies were singing. ${ }^{44}$ Of course, the household ladies were not exempt from their normal spiritual duties such as mass and praying the divine offices, and there should be no doubt the primary daily focus of each of the nuns' lives was liturgical. The nun who held the office of sacrist was

\footnotetext{
${ }^{42}$ Sturman, 300-4.

${ }^{43} \mathrm{Ibid}, 349$.

${ }^{44} \mathrm{Ibid}, 352$. She points out that this practice was common to the houses of black monks.
} 
vital to this liturgical life, for she was endowed with the very important task of keeping up the abbey's sacred spaces and objects. Because daily devotion was the most important aspect of life in the nunnery, the sacrist had to be a well-organized, responsible person. She saw to the care of vestments, provision and care of candles, bells, books, and all of the ornament used during the abbey's various services. ${ }^{45}$ She also undoubtedly had great knowledge of liturgical practices and an eye for detail that was handy for remembering special needs such as when to prepare the tent for processions, candles for Candlemas Day, ashes for Ash Wednesday, and seeing that proper ornament was hung for feast days. ${ }^{46}$ Moreover, like all "departments" in the abbey, she was also the manager of her own funds. At Barking, the sacrist was aided by the precentrix and her assistant the succentrix, who made sure the ceremonies and chants were carried out correctly in the monastic choir. ${ }^{47}$ But even with this additional help, the sacrist was kept so busy that she was the only nun exempted from certain religious duties. ${ }^{48}$

After the sacrist, the most important of the obedientiaries was the cellaress. The cellaress was considered by monastic communities to be so important that Saint Benedict, in his Rule, specifically addressed only one other office - that of the abbess. ${ }^{49}$ The Rule directs that the cellaress should be chosen from the convent and

\footnotetext{
${ }^{45}$ Essex Monasteries (ERO, 1964), 21; Power, Medieval English Nunneries, 132; Sturman states there is no evidence that Barking Abbey nuns made the vestments, but rather that they bought the material, paid to have them made, and then the sacrist kept them clean and preserved (pp. 274-5).

${ }^{46}$ Sturman, 276.

${ }^{47} \mathrm{Ibid}, 277$.

${ }^{48} \mathrm{Ibid}, 276,453$.

${ }^{49}$ See Fox's English translation printed in Collett, 126-7.
} 
be wise, in good manners, sober, not proud, not troublesome, not slow, and not prodigal. Benedict obviously understood the gravity of the job and therefore the need for a prudent, conservative manager in this position, for he implores that "she shall suffer nothynge / though it be of lyttell value / to goo to waste / nor vnloked to norneclygently [negligently] left or loste." To complete all the cellaress is charged with, he further allows that "If the conuent be great / she shal haue helpe and comfort of other / by whose socour / she shall do hir duty and office conmytted vnto hir / with a goode wyll / without any grudgynge." ${ }^{, 50}$ At Barking we find the cellaress was indeed assisted by an under-cellaress, and between them they were responsible for the abbey's food and supplies. ${ }^{51}$

Providing for a community included a wide range of duties, an example of which appears in the Rule of Syon monastery

The Celeres schal puruey for mete and drynke for seke and hole, and for mete and drynke, clothe and wages, for seruantes of householde outwarde, and sche shall haue all the vessel and stuffe of housholde under her kepynge and rewle, kepynge it klene, hole and honeste. Ordenying for alle necessaries longynge to al houses of offices concerning the bodily fode of man, in the bakhows, brewhows, kychen, buttry, pantry, celer, freytour, fermery, parlour and suche other, bothe outewarde and inwarde, for straungers and dwellers, attending diligently that the napery and al other thynge in her office be honest, profitable and plesaunte to al, after her power, as sche is commaunded by her souereyne. ${ }^{52}$

Keeping in mind that Syon was a larger house, the position of cellaress at Barking nonetheless must have been an incredibly busy and challenging office to hold.

\footnotetext{
${ }^{50}$ See Fox's English translation printed in Collett, 126-7.

${ }^{51}$ Power, Medieval English Nunneries, 133; Sturman, 293.

${ }^{52}$ Power, Medieval English Nunneries, 133.
} 
Though many of Barking Abbey's records do not survive, we are fortunate to have an extraordinary document from the cellaress entitled the Charthe longynge to the office of the Celeresse of the Monasterye of Barkinge. ${ }^{53}$ The Charthe is undated, though Eckenstein suggests it is from "about the year 1400," and Loftus and Chettle date it to "perhaps the fifteenth century."54 This later-medieval dating seems correct given the fact that the document was originally written in English, the preferred language used by nuns in England at that point. Regardless of its date, however, the Charthe provides an interesting glimpse into not only the duties of the cellaress, but the daily life of the nuns for whom she provided.

The first order of business for the cellaress as outlined in the Charthe is to "luke, whanne she commethe into her office, what is owynge to the said office, by diverse fermours and rente-gederers, and see that it be paid as soone as she may." 55 This is followed by a list of the abbey's manors and the amount that each owes to her yearly. Keeping up the accounts receivable was, naturally, important for all departments in the monastery, but was doubly so for the cellaress who used her income to manage the farm and purchase additional foodstuffs and supplies as necessary. By the later Middle Ages, she had hefty annual revenues of approximately $£ 98$ at her disposal. ${ }^{56}$ Her income was also used to hire assistants; in addition to the under-cellaress mentioned above, Barking's cellaress employed three

\footnotetext{
${ }^{53}$ The Charthe printed in Dugdale, 80-3.

${ }_{54}^{54}$ Eckenstein, 372; Loftus and Chettle, 59.

${ }^{55}$ The Charthe printed in Dugdale, 80.

${ }^{56}$ Sturman, 291.
} 
cooks. ${ }^{57}$ She also employed a rent collector and clerk who helped her keep her accounts. $^{58}$

In addition to money payments to the cellaress, the abbey's manors also provided payments in kind such as grain for bread and ale. However, Sturman notes these provisions were generally inadequate in quantity, and therefore the cellaress had to purchase additional supplies of grain, oatmeal, malt, milk, and butter to meet her obligations for supplying food not only for the household, but also for the pittances required on the benefactors' anniversaries. ${ }^{59}$ Though the Benedictine Rule did not support it, travel outside the convent walls to purchase supplies for filling in gaps would have been occasionally necessary for the cellaress and her assistants. This was not a new practice in female monasticism; in the seventh century, Bishop Donatus included in his rule permission for the nuns to leave the convent for business purposes as long as they had authorization from their abbess. ${ }^{60}$ Jane Schulenburg has found that adherence to the early mandates of strict, active enclosure for nuns varied from house to house and country to country, citing evidence that "a certain freedom of movement was allowed, or in many cases simply assumed by abbesses and nuns." Venarde, in his study of Fontevraud and the Paraclete, also found regulations which acknowledged the practical necessity for

\footnotetext{
${ }^{57}$ Essex Monasteries (ERO, 1964), 22.

${ }^{58}$ PRO SC 6 Hen. VIII/929; Sturman, 297.

${ }^{59}$ Sturman, 293-4. See also the Charthe printed in Dugdale, under the heading "Pitance of the Covent," 81.

${ }^{60}$ Stephanus Hilpisch, History of Benedictine Nuns, translated by Sister M. Joanne Muggli, Leonard J. Doyle, ed. (Collegeville, MN: St. John's Abbey Press, 1958), 11.

${ }^{61}$ Schulenburg, 65-7.
} 
nuns to travel for convent business, and that a certain level of mobility for this purpose was deemed normal. ${ }^{62}$ The abbess of Wilton Abbey left no doubt of the importance of travel for conducting necessary household business in a letter she wrote to Thomas Cromwell in September 1535. In the letter, she complains that Cromwell's commissioners are trying to enforce a stricter level of enclosure, making conducting business difficult. She states that "As the house is in great debt, and is not likely to improve without good husbandry, which cannot be exercised so well by any other as by myself, I beg you will allow me, in company with two or three of the sad and discreet sisters of the house, to supervise such things abroad as shall be for [the house's] profit." ${ }^{, 63}$ Warren also provides several incidences from the travel expense records of various English nunneries to show that obedientiaries traveled frequently for abbey business. She argues that through their travels, which were discouraged by the church authorities advocating strict enclosure, the nuns were able to assert their "shrewd business acumen" and counteract the "institutional invisibility" insisted upon by the Church, thereby pushing their boundaries outside convent walls. ${ }^{64}$ Benjamin Thompson takes this a step further by arguing that monastics came and went so frequently for business and, sometimes leisure, that "the barrier between the cloister and society had become almost entirely permeable" by the late-Medieval period. ${ }^{65}$

\footnotetext{
${ }^{62}$ Venarde, $123-4$

${ }^{63} L \& P$, vol. 9 , no. 280.

${ }^{64} \mathrm{~N}$. Warren, 65-6.

${ }^{65} \mathrm{~B}$. Thompson, 186.
} 
However, while they did show competence in their business affairs by working to collect all that was due them and paying fair market prices for their goods, it seems a stretch to suggest the obedientiaries were somehow intentionally trying to expand their boundaries into the secular world by going out into it as needed to provide for their own sustenance. In the words of historian Ann Warren, "In order to live the ideal life, [nuns] had to make a bargain with real life."66 Travel was not always viewed as a luxury or means of escaping into secular life, but merely necessary for obtaining those items difficult or impossible to come by in any other way, such as the procurement of oxen. The Charthe suggests a supply of "twenty two good oxen," which were slaughtered every other week, throughout the year. ${ }^{67}$ To keep up with this demand, the cellaress supplemented the abbey's herd by purchasing oxen locally at markets such as Smithfield, Saint Albans, Uxbridge, Dunstable, and Kingston. ${ }^{68}$ In London, Cambridge, and at the Stourbridge fair, she also purchased large quantities of fish and eels for the Lenten diet. ${ }^{69}$ These were all items which could not be obtained in any other way, and at times when large purchases had to be made, the cellaress would send her representative to handle it for her. ${ }^{70}$ Therefore, though she and her assistants may have traveled when necessary, the cellaress' business acumen was probably exhibited more in her ability to manage

\footnotetext{
${ }^{66}$ Ann K. Warren, “The Nun as Anchoress: England 1100-1500," in Medieval Religious Women, John A. Nichols and Lillian T. Shank, eds., vol. 1, Distant Echoes (Kalamazoo, Mich.: Cistercian Publications, 1984), 209.

${ }_{68}^{67}$ PRO SC 6 Hen. VIII/929; The Charthe printed in Dugdale, 82; Sturman, 295.

${ }^{68}$ PRO SC 6 Hen. VIII/929; Sturman, 295.

${ }^{69}$ Sturman, 296.

${ }^{70}$ In 1526, the cellaress, Dorothy Fitzlewes, send her rent collector, John Morse, to Kingston and Dunstable to purchase forty oxen for her (Sturman, 295).
} 
effectively her own time and personnel. She did not necessarily seek the folly of the outside world, but merely did what had to be done to fulfill her duties as necessary by whatever means appropriate.

While the cellaress was the ultimate purchasing agent, ensuring that all food and supplies were on hand, it fell to the kitcheness to prepare the food, and to the fratress to see to the maintenance of the refectory (dining hall). The office of kitcheness seems to have been a permanent post at Barking according to the Charthe, which may have been exceptional since their Rule required the nuns to take weekly turns at service in the kitchen. ${ }^{71}$ Because Barking was a wealthy abbey, its members were able to afford a relatively varied and interesting diet. Due to the year-round slaughter of oxen, the nuns ate fresh beef three times per week (Sunday, Tuesday, and Thursday) except during Advent and Lent. ${ }^{72}$ This practice was also observed at Wilton Abbey, where according to Elizabeth Crittall, beef was the most common meat eaten, "appearing on nearly every day that was not a day of abstinence."73 This is a noteworthy comment on the status of these abbeys, because as C. M. Woolgar notes in his study The Great Household in Late Medieval England, fresh meat was expensive to procure, particularly in the winter months, and it was only eaten by household members with the highest rank. ${ }^{74}$ The nuns also ate pork, and to a lesser degree mutton (provided mainly for pittances), and of course, a large quantity of fish

\footnotetext{
${ }^{71}$ Eckenstein, 375-6. See also Fox's translation printed in Collet, 129-30 for "The xxxv chapitre treateth of the weekly kychynners."

${ }^{72}$ Power, Medieval English Nunneries, 564; The Charthe printed in Dugdale, 82.

73 Elizabeth Crittall, "Fragment of an Account of the Cellaress of Wilton Abbey, 1299," in Collectanea (London: Devizes, 1956), 146.

${ }^{74}$ Woolgar, 113.
} 
and eels during Lent. From wheat the baker made bread and the brewer, ale.

Oatmeal was provided once per week, and one bushel of dried beans was provided "against Midsummer."75 There was also butter, milk, eggs, crisps (fritters), crumbcakes, chickens, geese, spiced pies, and red wine - all eaten throughout the year at various feasts and designated times. During Lent, because of the overall blandness of the nuns' diet, the cellaress provided the cooks with rice, almonds, figs, raisins, and mustard to add variety and spice. ${ }^{76}$ Preparing all these foods for the nuns, their staffs, corrodies and guests must have kept the kitcheness hopping from early morning until late in the evening. As mentioned above, the fratress, of which Barking Abbey had two, was keeper of the dining hall and made sure the chairs and tables were clean and in good repair. ${ }^{77}$ She also saw to the purchase and maintenance of dish and tableware. ${ }^{78}$ The remainder of the Charthe provides detailed instructions to the cellaress on everything from the "offerings and wages" she is to pay, the anniversaries and pittances to be observed, the amounts and types of food to be provided (and when), to the "Hyreing of Pastur" and "Mowyng and making of heye." ${ }^{, 79}$ It is an amazing document for providing a sense of not only the scope of responsibility placed on the shoulders of the cellaress and her staff, but also of the day-in and day-out requirements for provisioning a monastery of Barking's size.

\footnotetext{
${ }^{75}$ Power, Medieval English Nunneries, 565-6; The Charthe printed in Dugdale, 83.

${ }^{76}$ PRO SC 6 Hen. VIII/929; The Charthe printed in Dugdale, 82.

${ }^{77}$ Essex Monasteries (ERO, 1964), 12.

${ }^{78}$ Power, Medieval English Nunneries, 132.

${ }^{79}$ The Charthe printed in Dugdale, 82.
} 
The English monasteries had differing numbers of offices depending on the house's size and wealth. Most had the basic positions already discussed, which were filled by nuns who acted as head of the house, keeper of religion and discipline, and those who were responsible for feeding and outfitting the community. Barking's Ordinale lists the additional offices found there as: librarian, circuitrices, searchers, mistress of novices, and almoness. ${ }^{80}$ Syon had even more with a separate treasuress, infirmaress and chambress. ${ }^{81}$ In the convent's household at Westminster, Barbara Harvey found no less than eleven departments, each with multiple assistants and servants. ${ }^{82}$ She adds to the list one "extra-departmental" function - the laundress, noting there were an "uncertain number" of them. ${ }^{83}$ In each house, it was up to the abbess to select her obedientiaries. At Barking, a nun had to be professed a minimum of seven years before she could be appointed to an office, which is an important indicator of how seriously they took their responsibilities if they restricted office holders to those they felt were mature and capable enough to handle the task. ${ }^{84}$ The appointments were made each year on the first Monday of Lent. The obedientiaries stood down from their offices on Sunday, and the abbess evaluated

\footnotetext{
${ }^{80}$ The Ordinale and Customary of the Benedictine Nuns of Barking Abbey, J. B. L. Tolhurst, ed. (London: Harris and Sons, Ltd., 1928), 68; Sturman, 269.

${ }^{81}$ Eckenstein, 390-2.

${ }^{82}$ Barbara Harvey, Living and Dying in England 1100-1540: The Monastic Experience (Oxford: Clarendon Press, 1993). Though it should be cautioned that the term "convent" was used in the Middle Ages to describe a religious house that could contain male monks as well as nuns. The use of the word in the modern era refers to an institution for women only. Because Westminster was a double house, Harvey uses it here to describe a mixed community.

${ }^{83}$ Ibid, 164 n. 68.

${ }^{84}$ Loftus and Chettle, 55; Oliva, The Convent and the Community, 85.
} 
their performance over the previous year. Those who had performed well were praised, rewarded, and reappointed; those who had not were replaced. ${ }^{85}$

It is clear this annual system of review and renewal enabled the sisters to maintain a level of competence among those who held important positions in the convent. Many of them exhibited their skills by holding their positions for several years, or better yet, by being promoted to higher offices. Oliva points out that in the diocese of Norwich, the histories of abbesses and prioresses show a high percentage of women who rose to those positions only after holding several lower offices. She cites two nuns of Carrow Abbey: Margery Palmer was cellaress for forty-four years before being elected prioress in 1485 , and Katherine Segrime served as both refectress and cellaress for several years before her election as prioress six years after Margery. ${ }^{86}$ At Barking Abbey, too, capable nuns generally moved through the ranks. Thomasina Jenney, who was sacrist before 1508 , was promoted to prioress and held that office until the dissolution in $1539 .{ }^{87}$ Margaret Scrope served first as precentrix in 1527 , then "lady of the pension" in $1535-6$, and finally was subprioress at the dissolution three years later. ${ }^{88}$ Competence can also be seen in the length of service of Barking's later abbesses, for in its last one hundred fifty years only two of seven held the office for fewer than thirteen years. Katherine de la Pole served an amazing forty years in the fifteenth century. ${ }^{89}$ The fact that these religious women possessed

\footnotetext{
${ }^{85}$ Loftus and Chettle, 55; Sturman, 268-9.

${ }^{86}$ Oliva, "Aristocracy or Meritocracy?", 206-7.

${ }^{87}$ Loftus and Chettle, 52; Sturman, 300, 439.

${ }^{88}$ Doyle, 234; Loftus and Chettle, 52; Sturman, 439.

${ }^{89}$ Loftus and Chettle, $42,48$.
} 
the ability to learn, grow, and be rewarded and respected for jobs well done is a key distinction between their lives and those of their secular sisters outside convent walls.

The balance of the offices performed the following functions: The librarian carried out the obvious task of caring for and circulating the monastery's books, both religious and secular if they possessed them. Not all monasteries were large or wealthy enough to have a designated librarian, but Barking was, and according to Sturman, the office may have dated to the thirteenth century. ${ }^{90}$ There was also a regular, annual tradition of book circulation for the nuns' education and enjoyment. ${ }^{91}$ At the dissolution, Barking possessed more than twenty texts and various manuscripts. ${ }^{92}$ Syon Abbey also contained an extensive library, which required two librarians. ${ }^{93}$ Evidence of this is found in a late-fifteenth century contract made between Syon's abbess and a bookbinder, which specifies "ye kepar of ye brethrens librarie [and] ye kepar of oure ye sistrenes librarie." 94 The circuitrice was responsible for "circulating" and ensuring that the nuns who were supposed to be engaged in their daily reading were doing so. Sturman notes there is no other reference to this office beyond that in The Ordinale and that it probably ceased to exist by the later Middle Ages, though she does not put forth an explanation for its

\footnotetext{
${ }^{90}$ Sturman, 280.

${ }^{91}$ Loftus and Chettle, 58; Sturman, 290.

${ }^{92}$ Loftus and Chettle, 58; Sturman, 289-90.

${ }^{93}$ For an in-depth discussion on female monastic book collections in England see David Bell, What Nuns Read.

${ }_{94}$ Margaret Deanesly, The Lollard Bible and Other Medieval Biblical Versions (Cambridge:

University Press, 1920, reprinted 1966), 340; Erler, 34.
} 
elimination. ${ }^{95}$ This office may have been related to the "reader" or legister, who was responsible for the weekly reading during meals as required by chapter thirty-eight of Benedict's Rule. ${ }^{96}$ The searchers, sometimes called scrutatrices, had the duty of "scrutinizing" the house and reporting disorder to the prioress. ${ }^{97}$ The mistress of novices was in charge of the novices (referred to as scolares at Barking), acting as their teacher and general guide, preparing them for the monastic life they would lead after they had professed their vows. ${ }^{98}$ The almoness attended to the abbey's almsgiving, which was required by the Rule. ${ }^{99}$ Barking Abbey's Ordinale does not mention the offices of treasuress, chambress, or infirmaress, duties which Loftus and Chettle surmise were carried out by committee. ${ }^{100}$ This seems plausible since a large abbey like Barking would most certainly require attendance to general fund management (treasuress), provision of clothing and bedding (chambress), and care of the sick and frail (infirmaress). ${ }^{101}$ Other monasteries had these officers, but the important thing to consider about the absence or presence of specific offices is the overall flexibility of a monastic system that allowed the nuns to make executive decisions themselves about how best to provide for their communities.

\footnotetext{
${ }^{95}$ Sturman, 271.

${ }^{96}$ Eckenstein, 391; See also Fox's translation printed in Collet, 132-3.

${ }^{97}$ Eckenstein, 216.

${ }^{98}$ Power, Medieval English Nunneries, 134; Sturman, 271-2.

${ }^{99}$ Power, Medieval English Nunneries, 132; Sturman, 299.

${ }^{100}$ Loftus and Chettle, 55.

${ }^{101}$ Sturman suggests the general funds were disbursed by the abbess, possibly with help from the steward (pp. 227,263). She also argues that Barking did not have a chambress, but that the nuns were paid an annual sum "for habit and vesture," which they, evidently, purchased for themselves (p. 302).
} 
Of course, despite all the above-mentioned responsibilities, we must not forget the nuns' primary "job" was praying for the souls of their founders and benefactors, and so daily life in Barking Abbey was dictated by these liturgical and spiritual obligations. One of those obligations was the praying of the divine offices, which according to the Benedictine Rule, were to be prayed daily. The offices in the order in which they were prayed were: Matins, Lauds, Prime, Tierce, Sext, Nones, Vespers, and Compline. Sturman points out that because Barking's Ordinale does not reference clock-time, it is difficult to determine the specific time each day when an office was prayed and for how long. ${ }^{102}$ Harvey has stated that in the Benedictine houses, Matins probably was said for one to one-and-a-half hours, but she does not address the remaining offices. ${ }^{103}$ Chapter eight of the Rule states that "mynchyns muste aryse at the viii houre after it be nyght / that is to saye / after the sonue be sette."104 This means the nuns arose at approximately 2:00 a.m. for Matins, and at varying intervals prayed throughout the day with the final prayer, Compline, said around 7:00 or 8:00 p.m. ${ }^{105}$ Adjustments were, of course, made for the changing length of the day from summer to winter. Mass was also said daily in the monasteries, and at Barking it was said three times. ${ }^{106}$

\footnotetext{
${ }^{102}$ Sturman, 349.

${ }^{103}$ Harvey, 156.

${ }^{104}$ See Fox's translation printed in Collett, 111.

${ }^{105}$ The Encyclopedia of Monasticism, 2 vols., William M. Johnston, ed. (2000) suggests a sample winter schedule as Matins 2:30 a.m., Lauds 5 a.m., Prime 6 a.m., Tierce 9 a.m., Sext noon, Nones 3 p.m., Vespers 4:30 p.m., and Compline 6 p.m. (p. 1433); However, Power points out that after Saint Benedict's time Nones was said at noon, leaving the aftemoon between Nones and Vespers for work (Medieval English Nunneries, 286).

${ }^{106}$ Desilets, 67; Loftus and Chettle, 56.
} 
Crucial to religious life at the abbey were the priests and chaplains whose sole task it was to attend to the nuns' spiritual needs. Their duties were in the sacraments, the mass, divine offices, special feasts, and processions. At the end of the fifteenth century, Barking had nine priests, and this number was probably smaller than it was previously. ${ }^{107}$ Given Johnson's assertion that "a common pattern was to have one priest/confessor for every fifteen to twenty nuns," we might expect to find upwards of one hundred eighty nuns in residence at Barking, though we know this was not the case. ${ }^{108}$ The high ratio of priests providing essential sacramental services to the nuns at Barking betrays the abbey's overall wealth and prestige, for priests were paid employees and dependent on the abbey for their keep. To have so many was an expensive endeavor not easily afforded by the majority of nunneries in England, and some historians have argued that having to pay priests for essential religious services that the nuns could not provide for themselves was a major contributor to the financial distress in many smaller houses. ${ }^{109}$ The priests received their meals from the cellaress and salaries and annual bonuses from the Office of Pensions. In the early-sixteenth century, the annual salary was £6. $13 s .4 d$., with an additional sum of $26 s .8 d$. for their "vesture" and "offerings at Christmas." 110 The interesting thing about the priests and chaplains at Barking is that they were not

\footnotetext{
${ }^{107}$ PRO SC 6 Hen. VIII/928; Loftus and Chettle, 56; Sturman, 326.

${ }^{108}$ Johnson, 181.

${ }^{109}$ Ibid, 183, 226; Power, Medieval English Nunneries, 144-6; See also B. Thompson, "Monasteries, Society and Reform," especially beginning p. 171 for an interesting discussion of changing economic and social climates. Though he writes about both nuns and monks, it is easy to argue from what he posits that nuns would have been less able to compete, and the added burden of paying priests would have been enough to send many nunneries over the edge into poverty.

${ }^{110}$ Sturman, 329.
} 
involved in the daily administration of the monastery, as they might have been in a smaller house. Those responsibilities fell solely to the abbess and her council. ${ }^{111}$ In a patriarchal institution such as the Catholic Church, where the priests were required because women could not say mass nor hear confession, it is important to note that in a large nunnery like Barking it was ultimately left to the women to govern both the priests and themselves for the benefit of their spiritual life.

The Rule of Saint Benedict required nuns and monks to provide for themselves through their own labor, but for a large house such as Barking, which in the sixteenth century never dipped below thirty in its number of nuns and novices (Appendix B), the ability to hire lay help was of vital importance. ${ }^{12}$ In this way the abbey was no different than a large manor house with its retinue of staff who aided in the household's daily chores. Loftus and Chettle note that the surviving records contain no clear evidence that the nuns "toiled, spun or gathered into barns." Benjamin Thompson notes that "monasteries were fundamentally part of the societies which provided the manpower and resources for their existence," so therefore we must assume the nuns employed laborers from the secular community to perform many tasks. ${ }^{114}$ For a nunnery, hired help enabled the sisters to

\footnotetext{
111 Sturman, 332-3.

112 Oxley, 282; Power, Medieval English Nunneries, 150. Though Power argues that by the thirteenth century the tradition of providing for themselves had been largely discarded because the nuns from the elite classes were unaccustomed to performing such menial tasks. Using Gilchrist and Oliva's estimate that nunnery populations generally consisted of a servant and lodger to each nun (Religious Women in Medieval East Anglia, p. 66), the number of people living in the monastery at Barking would have been very large and thus require additional hands to run efficiently. ${ }^{113}$ Loftus and Chettle, 56.

${ }^{114}$ B. Thompson, 168-9.
} 
concentrate on their primary function - their religious duties. Barking enjoyed this luxury due to its wealth and size, but Power points out that for the smaller houses poverty did not permit them to hire help, and several complaints are recorded by the nuns stating that their daily chores were keeping them from their spiritual obligations. ${ }^{115}$ We have already seen that for much of each day the nuns were engaged in praying the divine offices or going to mass, and on principal feast days (of which there were many) there was the required observance of additional offices. ${ }^{116}$ Therefore, it was crucial to the efficient running of the house that the sisters managed their own time well, as well as that of their employees.

The exact number of servants in the English abbeys is not known, and of course varied widely from house to house. Harvey, in her study of Westminster Abbey, takes issue with David Knowles' assertion that on average the ratio of servants to religious was $1: 1 .^{117}$ Harvey suggests this number is small because it only takes into account those servants who show up on the lists of the monastery's payroll. She argues there were at least three categories of servants who would not be found on the house's list of paid employees: (1) those employed independently by monastic employees such as the baker, (2) those employed by the nuns themselves and paid out of their own funds, and (3) those who worked for the monastery but never received cash payments, instead receiving payment in kind in food and

\footnotetext{
${ }^{115}$ Power, Medieval English Nunneries, 153.

${ }^{116}$ Loftus and Chettle, 56.

${ }^{117}$ David Knowles, The Religious Orders in England (Cambridge, 1948-9), 3:262-3.
} 
drink. ${ }^{118}$ Harvey's assertions make sense in light of what had to have been a very fluid atmosphere inside the nunnery, particularly from season to season. Using Knowles' rather conservative estimate, Barking Abbey during the later periods covered in this paper would have been a community of at least fifty to upwards of one hundred people at any given time. And the numbers only increase when we add to the servants who assisted the nuns on a daily basis those who were required for more seasonal or occasional work. ${ }^{119}$ The sisters were ultimately responsible for seeing to the daily needs of the house, which included hiring and supervising staff to help them. The constant creation and maintenance of relationships with workers in the lay community were undoubtedly some of the most important functions in the abbey.

Primary among the lay employees of the abbey, and often a prominent, local landowner, was the steward. As mentioned above, the steward often (especially after the thirteenth century) had legal knowledge or training. ${ }^{120}$ According to Power, not all monasteries employed stewards and some had more than one. ${ }^{121}$ The easy answer for the difference is the size and relative wealth of the institution. Smaller, poorer houses did not possess the number of landholdings and assets that required personal, legal oversight. Stewards (and sometimes bailiffs) were "mobile" employees who

\footnotetext{
${ }^{118}$ Harvey, 150-3.

${ }^{119}$ Barking Abbey existed for more than eight hundred years at the time of its dissolution in 1539 , therefore there must have been a constantly shifting number of various craftsmen required to maintain the buildings alone.

${ }^{120}$ Essex Monasteries (ERO, 1964), 20.

${ }^{121}$ Harvey, 165; Power, Medieval English Nunneries, 146. She also notes, interestingly in light of the Dissolution, that Thomas Cromwell was a steward at both Syon and Catesby monasteries.
} 
looked after the monasteries' lands and manors. ${ }^{122}$ While some abbesses enjoyed a level of mobility when household business required it of them, often they dispatched the steward to take care of business for them. A sixteenth-century account book of expenses and repairs at the abbey includes, among several others, the following four entries:

Itm payed to Mr. Broke for shoeng of hys horses at dyvers tymes rydyng on my ladyes busyness - iii $s$. iiii $d$.

Itm for Mr. Pownsettes expenses kepyng the courtes at Lytlyngton \& Slapton the $\mathrm{xvi}^{\text {th }}$ daye of maye - vi s. iii $d$.

Payed for Mr. Pownsettes expenses at London in Ester time for besynes for the howse - iii $s$. iiii $d$.

Itm paid for my ladyes expenses when she roode to Mr. Brokes $\mathrm{w}^{\mathrm{t}}$ rewardes geven at Mr. Stonardes $-v s$. viii $d .{ }^{123}$

Clearly, sometimes the abbess rode for her own business, while at other times it was necessary to pay her stewards to take care of abbey business. At Barking the cellaress was directed to pay the steward $20 \mathrm{~d}$. each time he returned with monies from the manor courts, with an extra $20 d$. bonus at Christmastime. ${ }^{124}$ These rewards, written down to remind all incoming cellaresses to be sure and pay them, indicate just how important the steward was in the daily management of the abbey's estates.

Just as in the great secular households in England, many of the employees of the great monasteries and abbeys lived in the house. These generally included the chaplains and also the household staff required for the daily chores such as cooking,

\footnotetext{
${ }^{122}$ Essex Monasteries (ERO, 1964), 20.

${ }^{123}$ PRO E 101/458/7. This part of the account book is datable, for William Pownsett served as the abbey's final steward from 1537-39.

${ }^{124}$ Sturman, 265 n. 2; The Charthe printed in Dugdale, 81.
} 
cleaning, and laundry. Therefore, not only did the nuns have to make sure the staff was dutifully completing the tasks they were hired to do, but they had to manage adequately the resources necessary to provide them with bed and board. Those employees not living in the house were generally married, and it was common in the monasteries to find the wife of a male servant helping out as well. ${ }^{125}$ This certainly may have been the case at Barking Abbey, for we find in the last abbess' will the following bequests to servants' wives, which probably represent rewards for their loyal service

Item I gyve to Richard Tyllwright my servaunt a trussing of Satten of Brydges with testar and Curtins a fetherbed a boulstar a blew Coverlett with xls. In money. And I gyve to his wiefe one payre of flaxen Shetes a playne table cloth and a single rayle.

Item I gyve to George Peake somtyme my Servaunt tenne shillings to by hym a cote and to his wiefe a fine playne towel and a single raylle.

Item I gyve to George Monk somtyme my Servaunt a playne tablecloth and to his wiefe a fine raylle. ${ }^{126}$

The last major category of hired lay staff was the farm laborers, who tended the abbey's farms and livestock. According to Power, these workers fell under the jurisdiction of the bailiff and the cellaress, who paid them and saw that they reaped the maximum produce from the abbey fields and herds. ${ }^{127}$

What is important to note from these various categories of hired help is that the nuns had to be adept at managing human resources. They also had to maintain

\footnotetext{
${ }^{125}$ Harvey, 167.

${ }^{126}$ The Will of Dorothy Barley, the last abbess, 1556, printed in Sturman, appendix III. Italics added.

${ }^{127}$ Power, Medieval English Nunneries, 150.
} 
good relationships with the nearby communities from which these workers were drawn. There were several types of arrangements that existed at any given time: seasonal laborers who worked only for food and drink; contracted workers who made most of their money as self-employed businessmen, but provided a good or service to the monastery; ${ }^{128}$ household or farm workers who received eighty percent of their income in kind plus small cash stipends; and finally, people like the chaplains and priests who lived in and completely relied on the abbey for everything including bed, board, and wages. To keep track of what must at times have felt like a revolving door of personnel, season-in and season-out, doubtless took diligence and competence.

\section{CONCLUSION}

English nunneries were clearly places buzzing with activity, and for their officer-nuns this meant high levels of responsibility and authority. It took considerable time and attention to detail to see that life inside an enclosed environment was carried out as smoothly as possible for all involved parties.

Though not all the nuns at Barking Abbey or her sister institutions aspired to hold office, nor were they all equally capable of doing so, those who did seem to have performed (for the most part) quite admirably.

It is curious to note that while historians of women's monasticism tend to recognize the opportunities for education, work, and advancement available in the

${ }^{128}$ Harvey, 176. 
nunnery, those who have written on women and work in general in the Medieval and Early Modern periods tend to ignore, or treat lightly, the women religious involved in convent administration. For instance, Women and Work in Preindustrial Europe (1986), edited by Barbara Hanawalt, focuses so completely on secular women that the words "nun," "monastery," or "religious" are not to be found in its contents nor its index. As well, Sisters and Workers in the Middle Ages (1989), edited by Judith Bennett, et al, has only one section concerning women's monasticism, and it focuses on expansion and decline in the period 500 to 1100 , failing to address office-holding patterns or administrative opportunities for religious women. David Herlihy actually includes a section titled "Convent" in his Opera Muliebria: Women and Work in Medieval Europe (1990), but he only briefly covers convents in Normandy, followed by a discussion of the Beguines. The thrust of his coverage of convent work hinges on the profit motive and restrictions on religious women's ability to make enough money to survive. ${ }^{129}$ As with Bennett, there is essentially no mention of the many and varied administrative responsibilities that nuns assumed in order to manage their communities. Though historians always wish there were more, there are several extant records from female religious communities, such as the cellaress' Charthe from Barking Abbey, which provide insight into the important jobs the women were performing. These documents need to be addressed further by historians of women and work in the Medieval and Early Modern periods.

\footnotetext{
${ }^{129}$ David Herlihy, Opera Muliebria: Women and Work in Medieval Europe (Philadelphia: Temple University Press, 1990), 61-70.
} 
To be sure, as Kowaleski and Bennett point out, there are differences of opinion about the opportunities for work, responsibility, and authority for women in the Medieval and Early Modern periods. ${ }^{130}$ Older historians such as Power and Eckenstein saw nunneries as havens for independence, in part because in the earlytwentieth century they themselves were experiencing an expansion of opportunities for women. More recent feminist historians, however, have tended toward the "glass is half-empty" approach, arguing opportunities may not have been as plentiful as previously suggested because, in the end, women's lives were still controlled by male interests, in the case of nuns, the male-dominated Catholic Church. ${ }^{131}$ There is probably some truth in both arguments. While it is true that nuns were ultimately answerable to the Church, which meant answerable to men, the reality remains that complete freedom from male influence was a rarity for any woman of that time. Nuns (especially abbesses) were remarkably adept at managing themselves within that patriarchal environment. Also, adequate documentation does survive, such as Barking Abbey's cellaress Charthe, Office of Pensions Account, and similar account books from several nunneries, both large and small, to show that the nuns' administrative obligations were extensive and indeed carried out daily by the sisters themselves and those they employed and supervised. Moreover, opportunities for education were generally better in the nunneries, for even elite women lucky enough to be educated often received their instruction in the convent. Education was a

\footnotetext{
${ }^{130}$ Maryanne Kowaleski and Judith M. Bennett, "Crafts, Gilds, and Women in the Middle Ages," in Sisters and Workers in the Middle Ages, Judith M. Bennett, Elizabeth A. Clark, Jean F. O'Barr, B. Anne Vilen and Sarah Westphal-Wihl, eds. (Chicago: University of Chicago Press, 1989), 21-2. ${ }^{131}$ Kowaleski and Bennett, 25.
} 
valuable commodity and an important component in the successful running of a household, especially when it came to complex activities like managing funds and legal matters. On balance, nuns were probably better equipped to handle their responsibilities than women in secular society because opportunities for education and outlets for administrative skill existed for women inside the convent more so than anywhere else. As Penelope Johnson so succinctly put it, "In no institution other than monasticism could women participate so fully in shaping their own lives."132

Though other historians of women's monasticism, particularly those interested in theories about a "golden age" for women, find it important (from a modern, feminist perspective) that medieval and early-modern nuns were occupying responsible positions of authority not experienced by most secular women, there remains a key element that is difficult to assess from the records - how the nuns themselves perceived their administrative obligations. This thesis argues that though opportunities for education, work, and advancement certainly existed in convents, most nuns did not enter monastic life specifically with these objectives in mind, but rather simply to serve God. All of the opportunities and responsibilities could have fostered a positive self-image, but the nun's true identity remained locked in her role as a bride of Christ. Late-medieval and early-modern nuns could not have perceived their "jobs" in the same way that professional women do in the twenty-first century. As such, while they probably viewed their offices as important and deserving of respect, they saw them primarily as necessary functions for sustaining their lives. To

${ }^{132}$ Johnson, 206. 
enable the house to thrive, Barking's abbess had to manage efficiently the house and its estates, including maintenance of relationships with patrons and tenants, so that revenues would continue to be raised. ${ }^{133}$ Likewise, the cellaress and kitcheness had to make sure the nuns were physically fed so that they could go about their business of spiritually nourishing themselves and others. The infirmaress had to tend to the nuns' sicknesses, hopefully making them well enough to ensure their prayers for the community would continue. And lastly, the mistress of novices had to see to the spiritual and intellectual education of her charges so that new nuns would be professed, ensuring the community continued after elderly sisters passed away. There were other jobs, of course, but the important point is that each had its own special place and role to be played with the sole aim of ensuring the institution's survival. In the end, all of this working and managing and supervising, seen by some modern historians as evidence that nuns had a better life than their secular sisters, were responsibilities probably seen by the nuns as merely necessary for sustaining themselves so that they could better serve God which, in the case of Benedictine houses like Barking Abbey, was required by the Rule that dictated their very existence.

\footnotetext{
${ }^{133}$ Some historians have remarked that the raising of funds and maintenance of a monastery's wealth proved a conundrum for institutions which were bound by vows of poverty and prohibition of personal property. However, Janet Burton argues this was not problematic for the nuns because the house's property and wealth was communal, and therefore allowed by the Rule. She also points out, as I argue in this paper, that the nuns worked to maintain the convent's wealth, which enabled them to feed and clothe themselves, primarily in order "to provide the material means to perform their task of corporate prayer for the welfare of humankind" (see Monastic and Religious Orders, 11).
} 


\title{
Chapter IV
}

\author{
Cultural Activity
}

The essence of communal life is regularity, but no human being can subsist without a further ingredient of variety.

\section{Eileen Power ${ }^{1}$}

We now turn to that part of the nuns' lives which was not spent in either devotional or administrative activities. Admittedly, praying and running the household occupied huge chunks of each day, but such a regular (and what at times must have felt excruciatingly monotonous) life begs the question: Did the nuns at Barking Abbey pursue any sort of cultural or artistic activities in their precious moments of leisure? And if so, how did they perceive those activities? Surely, the idea of occupying one's self in creative activities purely for enjoyment is a more recent phenomenon. But did this have to mean the vestments they embroidered or books they copied and read were viewed only as necessary elements in their lives no different from repairing a refectory chair or mending a torn cloak? Art historians have long argued that "art for art's sake" is a later development, and medieval men and women had almost no notion of producing an object for other than functional purposes.

\footnotetext{
${ }^{1}$ Power, Medieval English Nunneries, 285.
} 
But can we really believe that the nun who possessed a precious Book of Hours did not also covet and enjoy it as an object of beauty, even though its main purpose was to aid her in daily devotions? For purposes of this discussion, art objects and cultural activities are defined as those which are not integral to the sustenance of life, such as the provision of food and shelter, and which may be seen as enriching, fulfilling, or providing some level of enjoyment over and above their intended purpose. So, given this description, was it possible for cloistered nuns to conceive of a life enriched by art and craft the way we do in the twenty-first century? Unfortunately, answers to personal questions such as the nature or source of emotional fulfillment are difficult to find, particularly for Barking Abbey nuns where such scanty evidence survives. However, we can look at the small amount of evidence of cultural activities at Barking and perhaps postulate what those activities might have meant to its nuns.

It has long been commonly known that art was produced in monasteries, particularly during the Middle Ages. Any survey-level art history text will recount the beautiful and important manuscripts created at that time in the monasteries of Britain and Ireland, such as the Lindesfarne Gospels, The Book of Kells, or the Canterbury Psalter. The atmosphere of the monastery and, in the case of Barking, its abbey church, proved to be a rich source for artistic influence. In PreReformation England, churches and monasteries were ornately decorated with stained glass, textiles, various painted designs, illuminated manuscripts, sculptures, and metalwork. As Janice Burton points out

It is difficult for the modern visitor to appreciate how richly painted the walls of many monastic churches would have been. A few survivals 
serve to remind us of this fact, like the early twelfth-century chapel of the Holy Sepulchre at Winchester, which contains wall paintings depicting the crucifixion, deposition and burial of Christ, and the pillars of the nave of St. Albans with their crucifixion scenes dating from the thirteenth century. More ubiquitous would have been the coloured geometric designs painted on pillars and arcades and over windows. It is highly likely that the plainness of Cistercian churches, and those houses of canons regular influenced by them, and the lack of images therein, would have contrasted sharply with the decorated interiors of Benedictine churches. ${ }^{2}$

Another description familiar to historians of the Early Modern period is that of the Long Melford (Suffolk) churchwarden, Roger Martyn, who lamented the decoration that had been lost from his parish church during the Reformation. The church had contained "fair gilt" images of Christ's Passion and the Holy Trinity, a Pieta, and a rood with depictions of Mary and John and a rood loft which extended the breadth of the church with images of the twelve apostles painted on it. The church also had two organs and a roof that was "beautified with fair gilt stars." as he lovingly recounts in fine detail the church's decoration and rituals on various holy days. Despite his nostalgia however, Martyn's description is helpful for the historian to understand how an English parish church was outfitted, and how important that ornament was to its parishioners. If that level of lavish decoration and adoration existed in a common parish church, we can only image how much more beautiful the interior of an important and wealthy abbey church, such as Barking, would have been, and how influential the art and architecture was in the lives and devotions of its resident nuns.

\footnotetext{
${ }^{2}$ Burton, 157.
} 
Of course, decorating Christian spaces and objects of worship was a tradition dating back more than a millennium by the sixteenth century. The early Christians used art in the catacombs in Rome to glorify Christ and venerate their dead. As the Church grew in wealth and power, it sought more extravagant ways to adorn its buildings, vestments, and ornament. By the time of the Gothic period in the laterMiddle Ages, churches had become vast spaces with interior heights that soared toward the heavens and were filled with sculpture, paintings, and glorious multicolored light emanating from large stained glass windows. The images depicted in the sculptures, paintings, and windows were meant to instruct the viewer in Christ's life and teachings, encouraging emulation, and they were also meant to create a sense of awe and wonder. The interior of the church represented a small slice of heaven on earth. The monk Theophilus captured this essence when he wrote, "By setting off the ceiling panels and walls with a variety of kinds of work and a variety of pigments, you have shown the beholders something of the likeness of the paradise of God, burgeoning with all kinds of flowers, verdant with grass and foliage." For those churches fortunate enough to house relics (as did Barking Abbey), the magic of a beautifully decorated church interior made an important impression on the pilgrims who came to pay their respects. Church decoration was also an important way for patrons to express their piety and charity. Precious gems donated to adorn a chalice, cloth given for vestments, a family chapel built into a new church, or money given to

\footnotetext{
${ }^{3}$ Roger Martyn, The State of Melford Church as I, Roger Martyn, Did Know It, printed in Religion \& Society in Early Modern England: A Sourcebook, David Cressy and Lori Anne Ferrell, eds. (London and New York: Routledge, 1996, reprinted 2001), 11-13.

${ }^{4}$ Veronica Sekules, Medieval Art (Oxford: University Press, 2001), 77.
} 
commission a stained glass window (with the patron's name included in the design of course) reminded the parishioners of the convictions of the patrons' faith and their generosity in the name of God. As well, the craftsmen involved in building the churches and creating the decoration probably viewed their contributions as important expressions of faith. Throughout Christian history, the importance of the desire to experience God and heaven and to express devotion by beautifying and maintaining holy spaces and objects cannot be overstated.

Though art historians have long studied the Christian art tradition, they have not always been able to discern clearly who created the objects used in worship or adorning buildings. One reason for this is because much medieval Christian art, particularly complex projects, was created on a collaborative basis involving many different types of artisan such as sculptors, metal smiths, weavers, and painters. Another reason is that, socially, artisans were a level below merchants, with many from the upper peasantry, and therefore were not singled out and known for their artistry, working instead as anonymous craftsmen. ${ }^{5}$ The age of the superstar artist sought out for his or her style and expertise would have to wait until the Italian Renaissance. However, as previously mentioned, art historians do know that a great deal of Christian art was produced in monasteries. It is noteworthy that prior to the Gregorian reforms of the late-eleventh century many of the monasteries were double, housing both men and women. Therefore, as Whitney Chadwick has argued, it is impossible to determine if the art produced in these institutions, particularly

\footnotetext{
${ }^{5}$ Sekules, 46-50.
} 
illuminated manuscripts, was created by monks or nuns. ${ }^{6}$ Her argument seems plausible, particularly when considering that the overwhelming majority of "artists" never signed their works during the Middle Ages, making identification essentially impossible. We have no concrete way of stating that monks were the sole producers of works of art or, that nuns were somehow incapable of matching their brethrens' skills in this area. From the eighth century, English nuns were known to excel at needlework and indeed became famous for their exquisite embroidery. ${ }^{7}$ It does not seem, therefore, too far a stretch to suggest the same hands and eyes that were skillfully adept with the needle and cloth could also be so when copying or illuminating a manuscript. ${ }^{8}$ Clearly, the level of attention to detail required by both pursuits could be transferable from one medium to another and across gender.

Lina Eckenstein asserts that in female-only monasteries throughout Europe, many different forms of art making were undertaken, such as the needlework and illumination mentioned above, and also weaving and painting. She also states that "in all houses reading and copying books of devotion" were considered a part of cultural production. ${ }^{9}$ Likewise, David Bell has shown that writing and copying, particularly in Latin, was widely practiced by nuns, but cautions that this was primarily a continental phenomenon. However, there were nuns at Barking Abbey

\footnotetext{
${ }^{6}$ Whitney Chadwick, Women, Art, and Society, 2nd ed. (London: Thames and Hudson, 1997), 46.

${ }^{7}$ Eckenstein, 225-7.

${ }^{8}$ Alison Beach has proven that collaboration between male monks and nuns in manuscript production did exist in at least two twelfth-century Bavarian monasteries. See "Claustration and Collaboration between the Sexes in the Twelfth-Century Scriptorium," in Monks \& Nuns, Saints \& Outcasts: Religion in Medieval Society, Essays in Honor of Lester K. Little, Sharon Farmer and Barbara H. Rosenwein, eds. (Ithaca and London: Cornell University Press, 2000), 57-75.

${ }^{9}$ Eckenstein, 222.
} 
who were highly educated and culturally adept, and who exhibited their proficiency in language by translating Latin texts into vernacular works, as will be shown later in this discussion. Art historian Jeffrey Hamburger has also found that around 1500, nuns in Germany created Andachtsbilder (devotional pictures). ${ }^{10}$

His study of approximately one dozen extant drawings from Saint Walburg, a Benedictine abbey near Eichstätt, reveals an artistic talent that is at once simple and complex, traditional and original. He argues that for the nuns of Saint Walburg, "An image [took] the place of Scripture as a model for the life of prayer, and visionary experience [took] the place of written revelation." 11 Therefore, the art that was distinctively created by nuns for their own use in private prayer was as important to them as reading devotional tracts and, according to Hamburger, was completely shaped by the religious works in the nuns' library. ${ }^{12}$

Visual imagery, whether in the form of manuscript illuminations, textiles, stained glass, paintings, or sculptures, was seen by cloistered women as crucial to certain aspects of their devotional life and practice. For instance, pilgrimages, and the indulgences gained through them, remained important elements in Catholic worship in the fifteenth and early-sixteenth centuries. In the church oratory, Barking possessed a special cross which drew so many people that in 1400 the pope granted an indulgence of five years plus one hundred days for all penitents who visited the

\footnotetext{
${ }^{10}$ Hamburger, Nuns as Artists.

11 Ibid, 84.

${ }^{12}$ Ibid, 123.
} 
cross on the abbey's principal feast days. ${ }^{13}$ However, cloistered nuns were not allowed to make a pilgrimage journey outside convent walls. They therefore had to rely on the visual imagery within their monastery and church to aid them in this practice. $^{14}$

Pia F. Cuneo argues this is exactly how the nuns at Saint Katherine's convent in early-Renaissance Augsburg used their painted basilica cycle, and Hamburger notes that "A reproduction of the Holy Face permitted nuns unable to journey to Rome an interior, proxy pilgrimage, especially on the feast in its honor, the second Sunday after Epiphany."15 This recent art historical research into how nuns used various forms of Christian imagery certainly suggests that cloistered women found the images to be very important and helpful tools for enabling them to participate fully in the Christian experience. Hamburger takes this point a step further by suggesting that the reason why there are so few extant illuminated texts from nunneries is because the nuns used and adored them until they essentially disintegrated. ${ }^{16}$ While Hamburger makes a valid assertion that historians have typically ignored objects created and used by religious women (or at best relegated them to the catchall category of "folklore"), this new research perspective is helping historians to learn

\footnotetext{
${ }^{13}$ Calendar of Entries in the Papal Registers relating to Great Britain and Ireland, Papal Letters, vol. 5, A. D. 1396-1404, W. H. Bliss and J. A. Twemlow, preparators (London: Mackie and Co. Ld., 1904), 280, 333.

${ }^{14}$ See Kathryn M. Rudy's articles “A Pilgrim's Book of Hours: Stockholm Royal Library A233," Studies in Iconography 21 (2000): 237-63, and "A Guide To Mental Pilgrimage: Paris, Bibliothèque de L'Arsenal Ms. 212," Zeitschrift für Kunstgeschichte 63 (2000): 494-515, for interesting discussions on this phenomenon.

${ }^{15}$ Pia F. Cuneo, "The Basilica Cycle of Saint Katherine's Convent: Art and Female Community in Early-Renaissance Augsburg," Woman's Art Journal 19:1 (Spring/Summer 1998): 21-5; Hamburger, 196.

${ }^{16}$ Hamburger, chapter five.
} 
not only about the objects and cultural activities themselves, but about what they can tell us about life in an early-modern convent. ${ }^{17}$

Cultural production by nuns has been shown to take many forms, but the connection between women and the textile arts is probably the oldest. Needlework was something the majority of women learned from a very young age. It therefore makes sense that women who chose the religious life would have carried those skills with them into the convent. Some nuns did distinguish themselves through their fine embroidery of vestments and tapestry weaving, particularly, as Eckenstein has shown, English nuns in the eighth and then again in the thirteenth century. ${ }^{18}$ In the eighth century, English abbesses sent rich vestments and altar cloths, which had been created in their convents, to Boniface. The abbess of Ely monastery sent to Cuthbert of Lindisfarne silks which she had adorned with gold and jewels, and which remained at his tomb at Durham until the twelfth century. Cuthbert was likewise buried wrapped in a linen cloth sent to him by the abbess of Whitby. In the thirteenth century, silk embroidery, particularly for vestments, was an area where English nuns excelled. The English monk Matthew Paris wrote of Pope Innocent IV's astonishment at the beauty of the vestments worn by English clergy visiting Rome in 1246. The pope ordered some to be made and sent to Rome for his own

\footnotetext{
${ }^{17}$ Hamburger, $x x$.

${ }^{18}$ This interruption in dates between the eight and thirteenth centuries may be related to the Danish invasions in the ninth century, when many English monasteries were completely destroyed. Their traditions were destroyed with them, and the long phase of rebuilding England's monastic infrastructure certainly must have been a factor in why England's nuns did not resurface as renowned in the textile arts until the thirteenth century.
} 
use. ${ }^{19}$ Regrettably, because of the fragile and perishable nature of textiles, very few survive. Moreover, for nunneries such as Barking, the ravages of Henry VIII's reforms and the confiscation of monastic property make it even less likely that textiles could have survived because most were probably damaged, destroyed, or sold off to parties who made different use of them. Certain of the more luxurious vestments embroidered in silk and gold undoubtedly ended up on the backs of some elite women, who had them reconfigured into the latest fashion. ${ }^{20}$

Though there is no indication that textiles produced at Barking Abbey have survived, interesting archaeological evidence for textile art production in the early period of the abbey has been uncovered. During an excavation of the abbey site in the mid-1980s, many artifacts associated with spinning were uncovered. These included spindle whorls of bone, clay, and glass, loom weights, bone rods for a vertical loom, pins of various sizes, and numerous bone combs. Fragments of gold thread were also found, indicating that expensive and ornate clothing was being made at the abbey. The obvious assumption is that these articles of clothing were probably ecclesiastic garments. ${ }^{21}$ Winifrid Sturman has suggested there is no evidence the nuns at Barking made their own vestments, but rather they probably purchased them with funds distributed by the abbey's Office of Pensions. ${ }^{22}$ However, her study focuses solely on the abbey's later period and, moreover, was completed twenty-five years prior to the recent excavations, so she had no way of

\footnotetext{
${ }^{19}$ Eckenstein, 224-30.

${ }^{20}$ I owe this point to Dr. Caroline Litzenberger.

${ }^{21}$ Kenneth MacGowan, "Barking Abbey," Current Archaeology 149 (1996), 175.

${ }^{22}$ Sturman, 275.
} 
addressing this new and interesting evidence that textile arts were practiced at Barking at an apparently sophisticated level. Also, the account book to which she refers includes entries for both purchase of material and payments made for repair of vestments. ${ }^{23}$ Perhaps the nuns were at times making their own vestments, while at other times paying to have them made or repaired depending on the most expedient use of their resources and time.

In 1990, additional discoveries of art production were made at the Barking site. A glass furnace was uncovered, again from the abbey's Anglo-Saxon period, along with finished glass pieces of a very high quality. Glass work was common by this period, and decorative glass has also been found at Shaftesbury Abbey that probably dates to the same time. ${ }^{24}$ Kenneth MacGowan, in his article on the dig, cautions that because no glass slag (waste product from glass manufacture) was found at the site it cannot be assumed glass was being made there, but he adds there is no doubt glass was being worked into art objects on or near abbey grounds. Most of the remnants found were reticello glass rods, which were used to decorate glass vessels and made by twisting colored glass rods together. Eighty-one different rods were combined to create the finest surviving fragment. ${ }^{25}$ MacGowan notes that both the spinning-related objects and the glass furnace and remnants were found on land that was part of the abbey's original land grant. However, he cautions that these findings may have come from workshops that supplied the abbey, rather than shops

\footnotetext{
${ }^{23}$ PRO SC 6 Hen. VIII/928.

${ }^{24}$ Donald B. Harden, "A Glass Bowl of Dark Age Date and some Medieval Grave-Finds from Shaftesbury Abbey," The Antiquaries Journal 34:3-4 (October 1954): 188-94.

${ }^{25}$ MacGowan, 178.
} 
in which the abbey's nuns may have worked. ${ }^{26}$ So, though the fragments are interesting remnants of life in the abbey community, and certainly point to the fact that objects of beauty were either made or in use there, the question of the nuns' involvement in glasswork remains open. If they did not take part in actual production, it is certainly possible that the abbess and her obedientiaries would have had responsibility for overseeing the workshops on abbey grounds, thus ensuring the objects they required were produced. Instead of being artists, the nuns may have acted as patrons.

The only other evidence of art objects relates to items installed, not produced, at Barking: two portraits and a painting of Saint Albrew, which hung someplace in the abbey. A sixteenth-century account book from the abbey's Office of Pensions shows more than ten shillings were paid for commissioning the Saint Albrew, which included the painting, retrieving, and setting up of the work. ${ }^{27}$ The other two portraits were of a Thomas Kemp and Humphrey Duke of Gloucester. Both were hung in the abbey in the late-fifteenth century. The Kemp portrait was a logical choice, for Kemp was the Bishop of London, and Barking Abbey was situated in the London diocese. Moreover, the Kemp family was connected to abbey inmates; an Alice Kempe entered the abbey in the late 1520 s, though she may have died not long after for she does not appear on the list of the last nuns at the dissolution in 1539, and a Margaret (or Margery) Kempte was a nun there from at least 1516 until the

\footnotetext{
${ }^{26}$ MacGowan, 178.

${ }^{27}$ PRO SC 6 Hen. VIII/928.
} 
dissolution. ${ }^{28}$ A connection between Humphrey Duke of Gloucester and Barking that would warrant having his portrait hanging in the abbey is more difficult to determine. Humphrey had served as Protector and Defender of England and the English Church, and principal councilor of the king from 1422 to $1429 .^{29}$ After the death of the Duke of Bedford in 1435, Humphrey became heir presumptive; however, most of his power came to a halt with his wife's arrest under the charge of sorcery against the king in 1441 . Humphrey was subsequently arrested in 1447 by William de la Pole, Fourth Earl of Suffolk and the king's chief advisor. ${ }^{30}$ At the time, William's niece, Katherine de la Pole, was the abbess at Barking and continued in that capacity until 1473. This association between Humphrey and the de la Pole family seems hardly a reason for the abbey to possess the Duke's portrait. Loftus and Chettle state the portrait was placed in the abbey "about 1489," but unfortunately offer no further clues. ${ }^{31}$

In addition to art objects, dramatic procession could also be seen as a cultural outlet, for it had become an important part of both civic and religious celebrations by the fifteenth century. In a monastery, there were liturgical processions, processions to greet the bishop, funeral processions, and celebratory processions on feast days. ${ }^{32}$ Evidence of Barking Abbey's Easter procession of the Harrowing of Hell survives in

\footnotetext{
${ }^{28}$ Loftus and Chettle, 49.

${ }^{29} 2002$ National Politics Web Guide, "Humphrey Duke of Gloucester," 14 February 2003, $<$ http://lego 70.tripod.com/england/humphrey gloucester.htm> (15 November 2003).

${ }^{30}$ The Columbia Encyclopedia, Fifth Edition, 1994-5, "Humphrey Duke of Gloucester," n.d., $<$ http:/www.slider.com/enc/22000/Gloucester_Humphrey duke of.htm> (15 November 2003).

${ }^{31}$ Loftus and Chettle, 49.

32 Johnson, 140.
} 
its Ordinale and Customary. ${ }^{33}$ The fourteenth-century abbess, Lady Katherine de

Sutton, who served from 1358 to 1377 , evidently became alarmed at the accidia overtaking the nuns in her charge. ${ }^{34}$ Accidia was a mixture of boredom or apathy and depression, which certainly could have been caused by the monotonous routine of religious life, but could also have been worsened by the Black Death, which had ravaged England less than a decade earlier, killing a large portion of monks and nuns. Looking to combat this melancholia, Katherine commissioned liturgical plays, including the Harrowing of Hell. The Harrowing was based on the account in Matthew 27, verses 51-3, and the Gospel of Nicodemus. ${ }^{35}$ It consisted of three parts: Christ's breaking down the gates of hell after his crucifixion; the binding of Satan; and the liberation of prophets and patriarchs from hell. ${ }^{36}$ Two of the three events were recounted in Barking's procession, for as Ann Faulkner asserts, the binding of Satan should not be expected to appear due to "the practicalities of staging [which] would have presented insurmountable problems of decorum." 37

\footnotetext{
${ }^{33}$ The Ordinale, 107-9; Barking Abbey's Harrowing of Hell procession was re-enacted in a play by the Chicago Medieval Players in 1989, see Ann Faulkner, "The Harrowing of Hell at Barking Abbey and in Modern Production," in The Iconography of Hell, Clifford Davidson and Thomas H. Seiler, eds. (Kalamazoo, MI: Medieval Institute Publications, 1992), 141; Sturman, 364-6. See also Karl Young, The Drama of the Medieval Church, vol. I (Oxford: Clarendon Press, 1933, reprinted 1951), pp. 149-77 for a more complete description of the play including references to Barking Abbey's production.

${ }^{34}$ Faulkner, 141; Power, Medieval English Nunneries, 293-4.

${ }^{35}$ The Gospel of Nicodemus is one of the apocryphal gospels of early Christianity. It contains accounts of Christ's trial, resurrection, and descent into bell. Historians believe the three acts were written independently by different authors in the fourth century, C. E. Also known as the Acta Pilati, or "Acts of Pilate," they are not believed to have been written by Pilate, but based on his official acts. The term Gospel of Nicodemus is of medieval origin. The Harrowing of Hell play performed at Barking is based on the third part of the gospel only. See Young, The Drama of the Medieval Church, vol. I, 149. See also George J. Reid, The Catholic Encyclopedia, vol. I, "Acta Pilati," 15 September 2003 , <http://www.newadvent.org/cathen/0111lb.htm> (22 January 2004).

${ }^{36}$ Faulkner, 142-3.

${ }^{37}$ Ibid, 143.
} 
The Harrowing took place in the abbey church, wherein the abbess, her nuns, and the clergy (in that order) solemnly proceeded from their stalls in the choir toward the westwork and to a side chapel. Because of the destruction of Barking's abbey church, it is difficult to determine to which side chapel they walked. However, Faulkner suggests a small chapel in the south transept because the group would have proceeded down the church and to the left (both "down" and "left" being directions associated with the Devil). Everyone carried an unlit candle, which symbolized burial and exorcism. ${ }^{38}$

The priest then went to the chapel with two deacons, who carried a cross and a censer, followed by the other priests and two boys who held lit candles. As they approached the chapel door, the antiphon Tollite portas was spoken three times, then

Qui quidem sacerdos representabit personam christi ad inferos descensuram et portas inferni dirupturam . et predicta antiphona unaquaque uice in altiori uoce incipiatur quam clerici tociens eandem repetant, et ad quamquam incepcionem pulset cum cruce ad predictum ostium . figurans dirupcionem portarum inferni . et tercia pulsacione ostium aperiat. Deinde ingrediatur ille cum ministris suis interim incipiat quidam sacerdos in capella existente. ${ }^{39}$

[Indeed the priest who shall represent the person of Christ to descend to hell and tear down the gates of hell. And the agreed antiphon shall be begun, [sung] continuously in a higher voice, the clerks repeating in the same way, and yet at the beginning of each time the priest shall strike with the cross at the agreed door, representing the destruction of the gates of hell. And with the third strike, the door opens. Then with his ministers, the priest emerges into the chapel, while another priest already in the chapel shall begin (the antiphon or response). $]^{40}$

\footnotetext{
${ }^{38}$ Faulkner, 146.

${ }^{39}$ The Ordinale, 107-8.

${ }^{40}$ I would like to thank Dr. John Ott for his assistance with this translation. An additional translation is printed in Faulkner, p. 147.
} 
From inside the chapel, the priest and the entire convent then began to sing for their souls' release from hell. After cries for help, the next antiphon Domine abstraxisti $a b$ inferis animam meam signaled the souls had been released. As the group left the chapel, they sang Cum rex glorie and proceeded through the choir to the sepulchre with palms and candles, which symbolized their victory over Satan. ${ }^{41}$ The procession's transformation from a cramped, quiet, and dark chapel to a brightly candle-lit church with voices lifting to the heavens must have been a sight and sound to behold and a moving experience for all involved, whether in the procession or merely watching it. And as Faulkner asserts, the experience had by the Chicago actors involved with the 1989 reproduction of Barking's Harrowing certainly indicates the dramatic procession would have been a remedy for accidia. ${ }^{42}$ No doubt it was similarly experienced by Barking Abbey's nuns.

Another important aspect of the religious and cultural life of nuns was singing and music. Evidence for this at Barking Abbey is found in the surviving hymnary with music from the late-fifteenth century and now in the library at Trinity College, Cambridge. ${ }^{43}$ The hymnal includes $O$ gloriosa Domina, which Loftus and Chettle contend was a favorite at Barking, with a plainsong melody in the "Ionian" mode. There are also three hymns for Saint Ethelburga, Barking's first abbess, and Saint Erkenwald, fourth bishop of London and the abbey's seventh-century founder. ${ }^{44}$ In its last years, music was not only sung, but also played at Barking

\footnotetext{
${ }^{41}$ Faulkner, 148-9.

${ }^{42}$ Ibid, 154.

${ }^{43}$ The Ordinale, introduction, $\mathrm{x} ; \mathrm{D}$. Bell, 108; Loftus and Chettle, 56.

${ }^{44}$ Loftus and Chettle, 56.
} 
Abbey, for the nuns possessed an organ that was purchased from a London contractor in $1519 .^{45}$ The importance of singing at Barking is reflected in the fact that the abbey had an office of precentrix. The precentrix was responsible for aiding the sacrist in the care and maintenance of the abbey's religious ornament and vestments, but more importantly she supervised the nuns who sang in the choir. As mentioned in chapter three, Barking had a special group of nuns who performed additional choral duties while the rest of the household was engaged in daily chores. This was a common practice among the Black (Benedictine) Monks, and no doubt the Black Nuns at Barking viewed their choral duties as important to their own devotional practices. ${ }^{46}$ Perhaps they found them enjoyable and spiritually fulfilling as well. At the very least, the nuns could take comfort in the fact that they were obeying Saint Benedict's mandate to "Syng ye wysely and intentyuely. And whansoeuer we conme to gydder / to synge the seruice of god / let vs take good hede / that our mynde accorde to our voice." ${ }^{47}$ Singing was considered a form of prayer and an expression of reverence toward God.

Cultural activities, however, do not have to be limited to artwork, drama, or music. If we accept that certain objects and activities in life may provide a sense of betterment or enrichment, then learning, writing, and the production or possession of books and/or manuscripts certainly must be included. As mentioned above, monasteries in the British Isles had a long history of learning and manuscript

\footnotetext{
${ }^{45}$ Loftus and Chettle, 56.

${ }^{46}$ Sturman, 349.

${ }^{47}$ See Fox's translation of the Rule printed in Collett, 119.
} 
production; however, Chadwick has argued that those traditions began to decline, particularly in the nunneries, when the Gregorian reforms were implemented. ${ }^{48}$ It is important to note that these reforms were being executed during the period of the rise of universities, which, on the surface, seems to contradict declines in learning. According to David Knowles, English universities were often overshadowed by those on the continent, but were actually havens of higher learning, particularly in arts and theology. There were intellectual Englishmen of such repute that between 1200 and 1350 the "most influential masters of the period" were more often English than any other nationality. ${ }^{49}$ Of course the problem with this great praise of the English university system and its highly educated men, and the point which Chadwick makes, is that women were not allowed access to university education. Just as religious men were receiving more intellectual opportunities, religious women were being reformed, further confined, and denied those same opportunities. ${ }^{50}$ For many English nunneries, particularly the smaller houses, declines in learning probably did ensue in this period, and it is telling that from this point forward nuns' ability to use Latin and then French diminished. David Bell, however, has shown this was not necessarily the case at Barking Abbey.

Crucial to literacy in the Middle Ages, particularly in a religious setting such as a monastery, was Latin literacy. Bell divides this into four levels: (1) the ability to

\footnotetext{
${ }^{48}$ Chadwick, 47.

${ }^{49}$ David Knowles, The Evolution of Medieval Thought, $2^{\text {nd }}$ edition, D. E. Luscombe and C. N. L. Brooke eds., (Essex: Longman Group Limited, 1988), 252-3; Janet Burton also discusses Englishmen of repute who were influential in continental monasticism in Monastic and Religious Orders, p. 265.

${ }^{50}$ Penelope Johnson points out the same educational disadvantaging for monastic women in her study of twenty-six northern French nunneries in Equal in Monastic Profession, p. 147.
} 
read without understanding; (2) the ability to read and understand liturgical texts; (3) the ability to read and understand nonliturgical texts; and (4) the ability to compose and write a text of one's own. ${ }^{51}$ Barking, with its long history of education and learned women, may have been exceptional in its continued acquisition and use of books in Latin almost to its dissolution in $1539 .{ }^{52}$ In the abbey's early history, Saint Aldhelm wrote De Virginitate for the nuns at Barking in a complex Latin, which he assumed the nuns could read, for he provided Old English or more understandable Latin translations for only the most difficult words. He wrote that he hoped the treatise would be "pleasing to [the nuns'] intelligence." The nuns corresponded with him in what Aldhelm referred to as "extremely rich verbal eloquence." He further praised their learning, stating that their wisdom enabled them to scrutinize "with careful application the hidden mysteries of the ancient laws," and also to examine the Gospels, the stories of chroniclers, the rules of grammarians, and the rules of metrics. ${ }^{53}$ In the late-eleventh century, Queen Maud, wife of Henry I, was educated at the Benedictine abbeys of Romsey and Wilton, setting the educational foundation for her later life, where she was "one of the most learned women of her generation, corresponding in excellent Latin with popes and archbishops, and earning the esteem of Hildebert of Le Mans." ${ }^{\text {54 }}$ She was a learned patron as well, for she commissioned a Voyage of St. Brendan in Latin and then later in Anglo-Norman vernacular. ${ }^{55}$

\footnotetext{
${ }^{51} \mathrm{D}$. Bell, 60 .

${ }^{52}$ Ibid, 66.

${ }^{53}$ Fell, 110-11; Loftus and Chettle, 14.

${ }^{54} \mathrm{D}$. Bell, 63.

${ }^{5 s}$ Susan Groag Bell, "Medieval Women Book Owners: Arbiters of Lay Piety and Ambassadors of Culture," in Sisters and Workers in the Middle Ages, Judith M. Bennett, Elizabeth A. Clark, Jean F.
} 
Around the year 1100 she became the abbess at Barking and remained so until her death in $1118 .^{56}$ As discussed in chapter two, Barking attracted women from the noble and aristocratic classes for most of its history; therefore, the odds were continually higher that its nuns had received an early education, possibly similar to Maud's, than had the nuns in smaller, poorer houses. ${ }^{57}$

David Bell has argued that Barking's nuns continued to use Latin texts almost to the end, which further reveals their elite, educated status, for, as mentioned above, almost all other English nunneries had ceased using Latin by around 1300 and French by the early-fifteenth century due to lack of knowledge. Therefore, it is unique in the larger scope of female monasticism, but perhaps not unique for Barking Abbey, to find nuns such as Clemence, who in the late-twelfth century translated a Life of St. Catherine of Alexandria from Latin into French verse, and an anonymous nun at Barking, who between 1163 and 1169 translated Aelred of Rievaulx's Life of St. Edward the Confessor from Latin into Anglo-Norman verse. ${ }^{58}$

O'Barr, B. Anne Vilen and Sarah Westphal-Wihl, eds. (Chicago: University of Chicago Press, 1989), 152.

${ }^{56}$ Loftus and Chettle, 29; $V C H, 120$.

${ }^{57}$ Both Marilyn Oliva and Claire Cross have acknowledged that in the nunneries of Norfolk, Suffolk, and Yorkshire, which were smaller and poorer than Barking, opportunities for education were not as good. Cross states that the number of books possessed by Yorkshire nunneries, when compared to Barking, was "meager in the extreme" (see "Yorkshire Nunneries in the Early Tudor Period," p. 151). Oliva points out, however, that even though educational opportunities may have been better at larger institutions, the ability to learn reading and writing still existed in Norfolk and Suffolk nunneries. Further, the nuns who entered convents from parish gentry or yeoman farmer families and became educated enough to hold convent offices elevated themselves above their secular sisters outside the convent, where they did not have the chance to learn. This, in turn, reflected positively on their families in the community (see "Patterns of Patronage," p. 161).

${ }^{58}$ D. Bell, 62, 69; Fell, 166; Loftus and Chettle, 30; Power, Medieval English Nunneries, 239. Loftus and Chettle state "The doors of Barking were still open to poets," citing a clerk named Adgar, who dedicated a version of his French poem on the Miracles of the Virgin to the abbess Maud in the same period that Clemence and the anonymous nun wrote their translations (p. 30). Clearly, learning and a love of literature were welcome at Barking Abbey. 
This discussion of Barking Abbey nuns, learned in their ability to read, interpret, and translate Latin, leads us to the largest surviving corpus of cultural objects or activities from the abbey - its collection of manuscripts and books, and its tradition of learning. A key element in the "dayly hande laboure" of a Benedictine nun was the amount of time chapter forty-eight of the Rule required her to spend in. daily reading. From Easter until the first of October nuns were to read for three hours each morning, and from October 1 to Shrovetide they read for two hours. During Lent they read for two hours each morning and "Uppon the sonday they shall all gyue them selfe to redinge / except those which be deputed to dyuers offices." There were other times as well, particularly after meals when the nuns were required to retire to their beds and lie quietly, but they were allowed to read so long as it did not bother others. ${ }^{61}$ The Rule even charged the two eldest sisters with circulating the house to ensure all who were supposed to be engaged in their daily reading were doing so. Those who were not were to be rebuked once and if caught twice, sent for "correccion."62 Clearly, Saint Benedict felt that reading was an activity suitable for enriching the soul, and so too, it appears, did the nuns at Barking, for the abbey had a librarian (an office not found in most nunneries) and an annual system of book lending, which is described in chapter forty-eight of the Rule and also in the abbey's Ordinale.

\footnotetext{
${ }^{59}$ See Fox's translation printed in Collet, 140-2.

${ }^{60}$ See Fox's translation printed in Collet, 141-2; Shrovetide is the three days preceding Ash Wednesday.

${ }^{61}$ See Fox's translation printed in Collet, 141 .

${ }^{62} \mathrm{Ibid}, 142$.
} 
On the first Sunday in Lent the librarian took all the abbey's books from the cupboard (armario) and spread them on a carpet in the chapterhouse. She then read out the names of each nun and the book they had borrowed the previous year. If the book had been read completely, the nun returned it and received another. If not, she received a penance, for the Rule required the book to have been read "from the beginninge to the endinge by order" before its return to the abbey's library. ${ }^{63}$

In a Benedictine nunnery, books mattered. We are fortunate that David Bell has recently undertaken a thorough cataloguing of Barking Abbey's surviving library, providing us with a list of fifteen manuscripts and twenty-nine books (Appendix D). ${ }^{64}$ Mary Erler has further supplemented Bell's list with an additional manuscript. ${ }^{65}$ Loftus and Chettle, in their 1954 history of the abbey, also mention the abbey's manuscripts and books, though it is clear more evidence had been uncovered in the forty-one years between their study and Bell's. Loftus and Chettle mention only "half-dozen" manuscripts and twenty-seven books, but they and Bell both agree that these surviving texts represent only a fraction of the library's original size. $^{66}$ Additionally, Loftus and Chettle state emphatically "There is no record of any printed books in this library," but Bell's research has inclined him to suspect that all of the twenty-nine texts were printed books. ${ }^{67}$ Shaftesbury and Wilton Abbeys were also among the top four wealthiest at the dissolution (with Barking and Syon),

\footnotetext{
${ }^{63}$ The Ordinale, 67-8; Fox's translation of the Rule printed in Collet, 140-2; Erler, 31; Loftus and Chettle, 58;

${ }_{64}$ D. Bell, 107-20.

${ }^{65}$ Erler, 145.

${ }^{66}$ Loftus and Chettle, 58.

${ }^{67} \mathrm{Ibid} ; \mathrm{D}$. Bell, 118.
} 
and yet the number of surviving texts for those houses is very low, ${ }^{68}$ We are fortunate to have so many extant texts for Barking, particularly those with nuns' inscriptions (which indicates a pride of ownership), for they help us to understand not only what the nuns were reading and perhaps copying, but also how the books and manuscripts were obtained, thus illuminating important information about how widely texts were circulated in the late-Medieval and Early Modern periods.

Though we are fortunate to have surviving books and manuscripts from Barking Abbey, the list is not without problems. David Bell, Patrick Carter, and the editors of English Benedictine Libraries: The Shorter Catalogues point out that the list comes down to us from William Pownsett, who was the abbey's final steward from 1537 to the dissolution in 1539 . The book list appears in the inventory of Pownsett's house in Eastcheap, taken after his death in March of 1554, as Certayne bookes yn the Abbey of Barkynge, and his executor accounted for them as "Also soche bookis as the testator lefte in thabbey of Barkynge at his deathe." descriptive headings raise red flags for the historian regarding whether the texts had belonged to Pownsett or the abbey. As the abbey's last steward Pownsett certainly could have taken the books, which might have otherwise been looted or destroyed at the dissolution, into his own possession, thus suggesting they had been part of the nuns' library. This hypothesis makes more sense than that gleaned from the executor's accounting of them as Pownsett's books left in the abbey, because by the

\footnotetext{
${ }^{68} \mathrm{D}$. Bell, 163-8, 213-4.

${ }^{69}$ D. Bell, 116-18; Patrick Carter, "Barking Abbey and the Library of William Pownsett: A Bibliographical Conundrum," Transactions of the Cambridge Bibliographical Society XI:3 (1998),
} 
time Pownsett died in 1554, the abbey had been destroyed for thirteen years. He had long since known there was no abbey left in which to deposit his collection of books.

The editors of English Benedictine Libraries argue that the nature of the list (primarily religious and devotional texts) makes it unlikely the books had been Pownsett's, since he was a lawyer and layman. ${ }^{70}$ Additionally, one of the surviving manuscripts is the abbey's Ordinale and Customary, which had been codified by the abbess Sibyl de Felton and given to the abbey in 1404, and in which is an inscription stating her provision that the book be used by future abbesses for guidance in the abbey's daily administration. ${ }^{71}$ No doubt this book was intended for, and probably never left the abbey's library. It seems exceedingly unlikely this text would have ever belonged to Pownsett. Moreover, it is highly unlikely that The Cleansing of Man's Soul or the various manuscripts in French belonged to Pownsett because they are inscribed as either gifts to or the personal property of the abbess Sibyl de Felton (Iste liber constat Sibille de Feltoun abbatisse de Berkyng). An additional manuscript, Vitas Patrum, is also inscribed "Thys bouke belongyth to Martha ffabyan" in two places. ${ }^{72}$ As noted earlier, Martha Fabyan was among the last nuns pensioned at the dissolution, therefore it seems highly unlikely she would have inscribed a book of Pownsett's as her own. Nonetheless, Bell takes issue with some of the assertions about the books having belonged to the nuns,

263-7; R. Sharpe, J. P. Carley, R. M. Thompson, A. G. Watson eds., English Benedictine Libraries: The Shorter Catalogues (London: The British Library, 1996), 13-14.

${ }_{71}^{70}$ R. Sharpe, et al, 14

${ }^{71}$ The Ordinale, v; D. Bell, 115; Doyle, 239-40; Loftus and Chettle, 46; R. Sharpe, et al, 13.

${ }^{72}$ D. Bell, 110-11, 116. 
primarily based on the fact that there were three legal treatises among them. Because Pownsett was a lawyer, Bell suggests they may have belonged to him. ${ }^{73}$ However, it is not inconceivable that legal reference works would have long been a part of the abbey's library by the time of Pownsett's tenure, particularly because Barking was a large and wealthy landholder frequently involved in legal disputes with tenants. The abbesses, their steward/administrators, or both could have used legal books.

Therefore, it does not seem necessary to jump to the conclusion that because their content was not religious, the legal books did not belong to the abbey. Bell's best advice is to proceed cautiously when considering the ownership of the Barking Abbey books, for they may represent a combination of books owned by the abbey and others. ${ }^{74}$

Not surprisingly, as with all nunnery libraries, the majority of the manuscripts in Barking's collection are of a religious or devotional nature. Several are in Latin an important distinction for houses such as Barking, Wilton, Dartford, and Romsey, all of whom had long histories of Latin learning. ${ }^{75}$ A perusal of the list of surviving works in Appendix D shows that essentially all of the manuscripts were for religious or devotional purposes except the Charthe longyne to the office off the Celeresse, which was an administrative account book prepared by the cellaress and her clerk. Among the religious works in Barking's collection was Nicholas Love's Mirror of the Blessed Life of Christ (Speculum vitae Christi). According to Eamon Duffy,

\footnotetext{
${ }^{73}$ D. Bell, 117.

${ }^{74}$ Ibid.

${ }^{75}$ Ibid, 77.
} 
Love's treatise was part of "a massive and growing literature in English designed to instruct and edify the laity and to provide the simple clergy with material for preaching and teaching." Love's very popular translation of the Meditationes Vitae Christi usually attributed to Bonaventure, the Mirrour of the Blessed Lyfe of Jesu, was among several that were directly commissioned or inspired by bishops specifically for edifying purposes. ${ }^{76}$

Barking also possessed various saints' vitae, including that of the first abbess, Ethelburga. It is often through mention of Saint Ethelburga and/or her immediate successors, Saints Hildelitha and Wulfilda, in the text or inscriptions that books or manuscripts can be identified as having belonged to Barking Abbey. Many of the vitae which survive were written by Jocelyn (Goselin) of Canterbury, the important eleventh-century hagiographer of English saints, after he visited the abbey. ${ }^{77}$ While Marvin Colker states it is unlikely Jocelyn's vitae were part of Barking's library because there are no press marks or ex libris inscriptions to indicate so, Bell argues that the appearance of the three abbess saints suggests the vitae were almost certainly among the abbey's possessions. ${ }^{78}$ The specificity of the women saints, not widely venerated throughout England but more characteristically in Essex, make Bell's argument seem more plausible. The balance of the devotional texts include tracts or extracts from Augustine, Jerome, and Erasmus, an English version of Vitas Patrum

\footnotetext{
${ }^{76}$ Eamon Duffy, The Stripping of the Altars: Traditional Religion in England c. $1400-$ c. 1580 (New Haven and London: Yale University Press, 1992), 61-2.

${ }^{77}$ Marvin L. Colker, "Texts of Jocelyn of Canterbury which relate to the history of Barking Abbey," Studia Monastica 7 (1965): 383-460.

${ }^{78}$ D. Bell, 108; Colker, 393.
} 
or lives of the desert fathers (which Erler states was a staple in monastic reading dating perhaps back to Saint Benedict's time and considered particularly appropriate for women, both lay and religious), a copy of the Song of Songs, Jacobus de Voragine's Golden Legend, books of sermons, a Psalter, a Book of Hours, and a Latin Bible. ${ }^{79}$ There was also an English Bible, most likely a Wycliffite translation according to Margaret Deanesly, which the Crown had given the nuns permission to use in the early-fifteenth century. This allowance was made for the larger, more educated nunneries (Syon Abbey had one as well) for both public and private use to aid in the nuns' understanding of the Vulgate. ${ }^{80}$

Finally, among the printed books on the list provided by Pownsett's estate are some interesting non-religious works which were fairly common in monastic libraries, such as Virgil's Aeneid, Cicero's De officiis cum commento, and Aristotle's Ethica. Also on the list was a copy of Aesop's Fables. Though complete catalogues of most monastic libraries do not survive, we can speculate from the inclusion of these classical texts about the wider range of book types that might be found within monastic libraries, based on the different ways that books could be obtained. A large, wealthy abbey was a busy place with frequent interaction - and thus the potential for book circulation - with other monasteries and the nearby secular community. As a royal foundation, Barking Abbey's primary patron was the king, and he often exercised his prerogative in sending favorites, who were likely in a

\footnotetext{
${ }^{79}$ Erler, 126.

${ }^{80}$ Deanesly, chapter thirteen, especially pp. 334-7; Sturman 287-8. Barking's English Bible does not appear in David Bell's research as a surviving text. Therefore, it may not have survived the dissolution, has been lost, or has yet to be uncovered.
} 
position to own books, to the abbey to live in retirement as corrodies. The larger abbeys were also known to draw their inmates from the upper social ranks, and those women may have brought books with them, as did the fifteenth-century abbess Sibyl de Felton. Sibyl also purchased texts for the abbey while she was abbess; in 1411 she purchased a volume of French theological writings (Paris, Bibliothèque Nationale, Fr. 1038) from the estate of Phillipa de Coucy, Duchess of York. ${ }^{81}$ Patron relations could also result in book gifts to the nuns. Elizabeth de Vere, the Countess of Oxford, is just such an example. Elizabeth was a member of the Scrope family, which was known for its collections of Latin, French, and English books, and which maintained connections with Barking Abbey to its end. Shortly before her death, Elizabeth gave to Barking a large manuscript collection (Magdalen College, Oxford, MS. 41) of various devotional works in French. ${ }^{82}$ Likewise, in the sixteenth century, Chaucer's Canterbury Tales was recorded by John Leland, in his Collectanea, as a codex belonging to Barking Abbey (the text does not survive and is thought to have been lost during the abbey's dissolution). Barbara Newman has suggested that William de la Pole, Fourth Earl of Suffolk, donated the copy of Chaucer's Tales while his niece Katherine was abbess at Barking in the fifteenth century. Given the fact that a relative of Geoffrey Chaucer became a nun at Barking in the latefourteenth century, and that William de la Pole's wife at the time of the book's donation to the abbey was Anne Chaucer, the poet's granddaughter, it is likely that

\footnotetext{
${ }^{81}$ D. Bell, 115-6; Doyle, 236; Loftus and Chettle, 46.

${ }^{82}$ D. Bell, 108, 112-15; Doyle, 233-8; Loftus and Chettle, 48.
} 
Newman's assertion is correct. ${ }^{83}$ All of these arrangements could, and frequently did, result in the movement of books and manuscripts both to and from the abbey's library, primarily because they involved people generally wealthy enough to own books. Lay society's growing interest in devotional literature had spurred an increase in the production and circulation of texts in the vernacular in the fourteenth and fifteenth centuries. ${ }^{84}$ These texts were frequently circulated between the laity and the religious, particularly by women.

With such varied potential sources, mixtures of subject matter such as that seen in Barking's surviving texts should not come as a surprise. Without complete catalogues of nunnery collections, however, it is difficult to determine exactly the size or contents of any institution's library, and we are left to extrapolate the scope of the library from the surviving texts and manuscripts. Among the subjects we might expect to find in a complete library collection are books helpful in the tasks of everyday life, such as cookbooks or medical reference works. Johnson points out that "In a time of limited medical knowledge, what was known about health care generally was available in monastic libraries. ${ }^{185}$ Charlotte Woodford also indicates that "every convent [in early-modern Germany] had a collection of medical books, containing remedies, which the nuns often made up from the herbs in their own

\footnotetext{
${ }^{83}$ Barbara Newman, "The Cattes Tale: A Chaucer Apocryphon," The Chaucer Review 26:4 (1992), 411-13.

${ }^{84}$ D. Bell, 14; Doyle, 232; Erler, chapter one; Vincent Gillespie, "Vernacular Books of Religion," in Book Production and Publishing in Britain 1375-1475 (Cambridge: University Press, 1989), 318-9. Eamon Duffy argues that Books of Hours, with their monastic origins, were particularly popular among the devout laity, who saw them as a way to emulate monastic devotion. See Stripping of the Altars, p. 210.

${ }^{85}$ Johnson, 51,53 .
} 
garden." ${ }^{86}$ And David Herlihy points out that monasteries were traditional places of medical learning (especially Benedictine houses after the Carolingian period), and that both men and women religious were seen by society as having expert medical knowledge, such as it was at that time. ${ }^{87}$ With such a long tradition within the Benedictine order (The Rule mandated the care of the sick), it certainly seems reasonable that Barking Abbey possessed medical treatises. In addition, it seems sensible that in a large kitchen such as Barking's (including a separate kitchen and cooking staff in the abbess' house) there would have been at least a few texts concerning food preparation.

Whatever the variety of texts, be they instructional, religious, classical, legal, or medical, the important point is that books and manuscripts were extremely important cultural objects. The fact that the nuns cared for and preserved them over centuries, so that subsequent sisters could benefit from and appreciate them, is a significant indicator of just how precious they were. Not only did the texts instruct, but they probably provided a sense of enjoyment as well. The Rule of Saint Benedict is very clear regarding the importance of reading for elevating the soul, and the nuns at Barking, with so many texts from which to choose, could rest assured that they were doing their part to live up to Benedict's ideal. In so many ways, the

\footnotetext{
${ }^{86}$ Woodford, 21.

${ }^{87}$ Herlihy, 107.
} 
abbey's books and manuscripts enriched the lives of generations of nuns who read, copied, and circulated them.

\section{CONCLUSION}

Though art objects could run the risk of conflicting with Saint Benedict's prohibition of personal possessions, most nuns probably viewed the items discussed above as communal property that was necessary to their monastic life and that benefited all the sisters in the house. ${ }^{88}$ Books and images were read as aids to devotion, vestments were embroidered for the Mass, decorative glass was spun into sacred vessels, and hymns were sung as a form of prayer. Clearly, each object or activity had its own special and specific purpose. Creation of any or all of these items by the nuns should not be seen as jeopardizing adherence to their Rule, but as acts that were necessary for fulfilling their religious obligations. In times of reform, Church authorities authorized monastic creativeness when a convent's books which had been deemed somehow inaccurate or insufficient had to be replaced. ${ }^{89}$ The monks and nuns were charged with copying the new, appropriate versions for daily use, thus bringing together two things seemingly diametrically opposed: restriction and creativity. ${ }^{90}$ By creating or commissioning objects of beauty necessary to the devotional life of the abbey, the nuns, as Hamburger puts it, "fulfilled the requirement that [they] engage in labor that was sanctified through prayer."91 The

\footnotetext{
${ }^{88}$ See chapter thirty-three of the Rule regarding property in Fox's translation printed in Collet, 128.

${ }^{89}$ Hamburger, 197.

${ }^{90}$ Ibid, 190.

${ }^{91}$ Ibid, 192.
} 
nuns no doubt acknowledged and enjoyed the beauty of art objects and creative acts, but their appreciation and sense of fulfillment was born out of a reverence for God and their faith, and not out of the objects or acts themselves. To Barking Abbey's nuns, creation was not dangerous but an act of worship in itself. 


\section{Chapter V}

The Dissolution of Barking Abbey

\section{Nov. 1539 BARKING ABBEY}

Surrender (by Dorothy Barley, abbess, and the convent) of the monastery and all its possessions in cos. Essex, Midd., Kent, Suss., Surr., Beds, Bucks, Herts, Camb., Suff., Norf., and Linc., the city of London and elsewhere in England.

14 Nov. 31 Hen. VIII. No signatures. [See Deputy Keeper's Eighth Report, App. II. 8.] Seal mutilated. Enrolled [Close Roll, p. 3, No. 43] as acknowledged, same day, before Wm. Petre, L.L.D., King's commissioner.'

This short and seemingly inconsequential entry in the massive volumes of Henry VIII's letters and papers officially signified that the door of Barking Abbey had been closed forever. Over eight hundred years of Christian service to the community and to England, dissolved. Though Barking was large and wealthy enough to escape the first parliamentary statute in 1536 authorizing the suppression of England's monasteries, in the climate of Henry VIII's disdain for the Catholic Church and need for money, it could not hold on forever. ${ }^{2}$ In the end, Barking Abbey's demise came, as with so many of the larger houses during 1538-40, as the result of steady government pressure. ${ }^{3}$ Reform had been the driving force behind the suppression of the smaller houses in 1536-7, but Henry had not been able to persuade

\footnotetext{
${ }^{1} L \& P$, vol. 14 , pt. $2,182$.

${ }^{2}$ Net value over $£ 860$ per annum according to Dugdale, $10,79-80$.

${ }^{3}$ R. W. Hoyle, "Origins of the Dissolution of the Monasteries," The Historical Journal 38, 2 (1995), 283.
} 
parliament that the larger monasteries and abbeys were corrupt, so after 1537 he readily resorted to "extra-parliamentary" means to achieve his goals. ${ }^{4}$ These means were required, as R. W. Hoyle argues, because a level of parliamentary ill will toward the monasteries that could lead to their complete removal probably did not exist. $^{5}$ Parliament did, however, eventually become involved, enacting 31 Henry VIII in its first session of 1539 , which in effect dissolved the remaining monasteries and abbeys and gave to the Crown full rights to monastic property. But in the early$1530 \mathrm{~s}$, it is quite possible no one could have foreseen the magnitude of Henry's plan, which was successfully carried out, and Barking was among the last houses to fall. This chapter will examine Barking Abbey's dissolution in the context of the larger "reform" movement, the process by which it was carried out, and the fates of the women who were its last inmates. Through this examination, this thesis argues that by eliminating the monastic way of life in the 1530 s, Henry VIII essentially eliminated the nuns' identities and abilities to contribute productively to society - a fate which was not suffered equally by male monks.

As discussed in previous chapters, nuns' lives were filled with many and varied responsibilities, both administrative and spiritual. In addition to their religious duties and devotions, they provided educational services, charity, economic assistance, and hospitality for the king's favorites, as well as care for disabled or illegitimate children, unwed mothers, and corrodies. ${ }^{6}$ Society generally had a high

\footnotetext{
${ }^{4}$ Statute 27 Henry VIII c. 28, printed in Youings, 155-9; Hoyle, 300-1.

${ }^{5}$ Hoyle, 300.

${ }^{6}$ Desilets, chapter V; Oxley, 51-3. Oxley's arguments in general tend to be apologetic for and favorable to the dissolvers, not the dissolvees.
} 
opinion of the monasteries in their communities, and despite the author's bias, the following quote concerning the 1539 suppressions of the larger houses from Stowe's Chronicle provides a hint of the various important services a monastery provided for its community:

The common people well liked them, and generally were very fond of them; because of the hospitality and good housekeeping there used. The inhabitants of these cloisters relieved the poor, raised no rents, took no excessive fines upon renewing of leases: and their noble and brave built structures adorned the places and countries where they stood. The rich also had education here for their children. ${ }^{7}$

Though Oxley questions whether the dissolution, and services lost as a result, really affected most people, Barking's surrender most certainly would have had an effect on those people who depended on it for their livelihood. ${ }^{8}$ While lay administrators such as William Pownsett, Miles Bowdish, and Edward Broke continued to administer the estates for the Crown as they had done for the abbess, laborers farther down the hierarchy had fewer prospects since Barking was not turned into a private manor as several monasteries were. In the monasteries that became private homes, servants or farm workers often had the opportunity to transfer their services to the new owners and thereby enjoy continued employment. ${ }^{9}$ However, other workers who depended on Barking Abbey were not so fortunate because the abbey was completely destroyed by the end of 1542 , which forced them to secure other means for

\footnotetext{
${ }^{7}$ Desilets, 579.

${ }^{8}$ Oxley, 256.

${ }^{9}$ Clapham, 73.
} 
their survival. Employment opportunities were just one of the reasons why Barking represented a safety net for so many, particularly the poor, in the greater abbey community. By dissolving the monastery, Henry effectively yanked that net out from under them.

Most important, however, was the abbey's raison dêtre: their religious devotions and spiritual duty to their patrons. As with all monasteries, the inmates' primary function was to see to the spiritual needs of their benefactors through prayer. Loftus and Chettle, in their history of the abbey, give an inkling of this primary spiritual relationship between the nuns and their Essex patrons:

Sir Ralph Hastings, of Wanstead, by his will dated in 1495 , desired to be buried in Barking abbey if he could not be buried at Syon. Richard Wanor, of Barking, dying in 1501, desired to be buried in the Abbey or in St. Margaret's [the Abbey church], and he bequeathed $10 \mathrm{~s}$. in money (or an equivalent cow) to the high altar. $£ 2$ towards building the steeple of St. Margaret's, and 12p. for every lady in the abbey to pray for his soul. ${ }^{10}$

As well, Sir Thomas Tyrell left $£ 36 s .8 d$. "to the nuns of Barking, to pray for my soul, for my wife Anne, and for my father and mother," when he died in $1477 .{ }^{11}$ Nuns' parents, extended family members and family friends also frequently made bequests to individual nuns and the larger abbey community as well. ${ }^{12}$ These bequests were important sources of income for the abbey, but they also signify the important and lasting link between the nuns, their patrons and the lay community at large.

\footnotetext{
${ }^{10}$ Loftus and Chettle, 49.

"Sturman, 412.

12 See chapter three of this thesis.
} 
The Ordinale, which was compiled by Barking's abbess Sibyl de Felton and given to the abbey in 1404 , outlines all of the religious observances kept by the nuns every day, year-in and year-out. ${ }^{13}$ The nuns were to attend Mass, which was celebrated in the manner of Saint Paul's Cathedral, thrice daily. ${ }^{14}$ Divine offices were to be said in accordance with the Rule of Saint Benedict, and the singing of psalms performed in the manner of the Roman Court. ${ }^{15}$ However, even with The Ordinale to guide them in their devotions, the amount of secular interaction engaged in by the nuns during their day-to-day administration of the house must certainly have, from time to time, created a tension between their active and contemplative lives. The question arises, were they ever derelict in their devotions? Sturman points out that because The Ordinale indicated what the nuns were supposed to observe, rather than what was actually observed, it provides no evidence to suggest whether the nuns at Barking were or were not negligent in fulfilling their daily religious obligations. Unfortunately, the Valor Ecclesiasticus, which reported the findings of the visitation in the mid-1530s, has been lost for Essex. We shall, therefore, never know how steadfast the nuns at the very end of the abbey's history were in their devotions. However, another visitation of Barking Abbey was made when Bishop Fitzjames of London made a visit to the house just thirty years prior to the dissolution. The record of that visitation makes no mention of lax behavior where the daily offices and prayers were concerned. ${ }^{16}$ Many of the nuns who

\footnotetext{
${ }^{13}$ Loftus and Chettle, 46.

${ }^{14}$ The Ordinale, 246-8.

${ }^{15}$ Loftus and Chettle, 56.

${ }^{16}$ Sturman, 472-3.
} 
appeared to be obediently observing their offices and prayers at that time were also present at the abbey's dissolution three decades later, so in all probability they were similarly observant then as well.

Though they were valued by medieval society, the concept of dissolving religious institutions in England was not new with Henry VIII. Throughout the latethirteenth and fourteenth centuries there were several petitions and enactments to dissolve alien priories. The motivation, however, seems to have had much to do with xenophobia and greed. Most of the alien houses were French, and as such housed foreigners with allegiances to their "mother" houses on the Continent. It followed, therefore, that the income earned by these houses did not stay in England, but was sent back to France - a fact that did not sit well with the Crown. So eventually under Henry V all the alien priories were successfully eliminated. ${ }^{17}$ Dissolution of the monasteries had also been discussed in the Commons under Henry IV and Henry V, though because they lacked the political punch to effectively challenge the Church, it never came to pass. ${ }^{18}$ It was not until Wolsey's crusade against the monasteries in the 1520 s (to funnel wealth to his newly founded Oxford College), that the concept was revived. Wolsey eventually obtained permission from both the pope and the king, and under the guise of reform suppressed any monastery valued at 3,000 ducats or less. With these suppressions, which were carried out swiftly (including six

\footnotetext{
${ }^{17} \mathrm{VCH}, 88$.

${ }^{18} \mathrm{Ibid}, 91$.
} 
houses in Essex) and were completed by March 1525, the precedent had been set and would eventually lead to the full-scale dissolutions that began eleven years later. ${ }^{19}$

Henry's disagreement and subsequent break with Rome, and the Crown's need for financial resources were the main motivations for the monastic dissolutions in the 1530 s. Henry argued the need for money for defense, but the need for funds to fuel the court's extravagant lifestyle was probably the overriding factor. ${ }^{20}$ In the summer of 1534, after his Oath of Supremacy had been declared, twelve signatures were obtained from Barking Abbey recognizing Henry's role as the head of the English Church. ${ }^{21}$ Thomas Cromwell, Henry's influential secretary, meanwhile seized upon the opportunity to use the monasteries to strengthen the Crown and, using the experience he had gained while helping Wolsey with the suppressions in the 1520 s, was successful in convincing parliament to engage in visitations meant to bring about monastic reform. ${ }^{22}$ The visitations of all monastic houses in the land, regardless of size or wealth, were carried out in late 1535 and early 1536.

Although she probably would have known Wolsey had been successful in the earlier suppressions, one has to wonder, once the official "visitors" arrived, whether Barking's abbess could have seen what was ultimately coming. Or, would she have merely endured the visitation, viewing it as an uncomfortable but mostly

\footnotetext{
${ }^{19} \mathrm{VCH}, 88-9$.

${ }^{20}$ M. D. Palmer, Henry VIII, Seminar Studies in History, gen. ed. Roger Lockyer (London: Longman, 1983), 53.

${ }^{21}$ Loftus and Chettle, 51; Sturman tells us the twelve signatures all came from men, and that no nuns' names appear (p. 417).

${ }^{22}$ Roger Bigelow Merriman, Life and Letters of Thomas Cromwell, vol. 1 (Oxford: Clarendon Press, 1968), 165-6.
} 
administrative exercise on Henry's part now that he had gained royal supremacy? The abbess at Wilton Abbey certainly did not appear to be concerned about that house's future, though an undeniable anxiety is detectable in a letter written by her to Cromwell in September 1535 after visitations of the convent had been completed. Her concern, however, was clearly not over the possibility of being suppressed. Her objection was to the strict enclosure the commissioners were trying to enforce because it made necessary household business difficult to conduct. ${ }^{23}$ Like the abbess at Wilton, it is possible - at least in the beginning - that Barking's abbess felt no reason to be overly concerned, particularly because of the abbey's recognition of Henry's supremacy. Up to this point, Henry had never publicly given the impression he wanted to completely abolish the monasteries, and as one of only four abbesses holding directly of the king, Dorothy may have had no choice but to trust him. ${ }^{24}$ Ironically, she had sworn an oath of fealty to Henry upon her election as abbess in 1527 wherein she agreed to be faithful, true, and obedient to him, swearing that "diligently I shalbe attendant unto the kynges nedes."25 Clearly, she had no choice but to do as he willed, though she probably never imagined it would mean the end of her monastic life.

Sir Thomas Audeley, the Lord Chancellor, appeared concerned for Barking's safety when he sent a letter to Cromwell on 30 September 1535 begging for a postponement of the visit to Barking until his return so that he might first speak

\footnotetext{
${ }^{23} L \& P$, vol. 9 , no. 280 .

${ }^{24}$ Desilets, 324.

${ }^{25}$ Sturman, 373-4.
} 
with Cromwell about it. He went on to say he understood Dr. Lee [Legh] (one of Cromwell's deputies) had been appointed to perform the visitation and clarified that his concern was not from suspicion of Lee. ${ }^{26}$ This clarification was no doubt political, for Dr. Lee was notorious in carrying out Cromwell's wishes. And Audley's concern for the abbey may not have been entirely selfless, since he was the beneficiary of two of the abbey's manors after the dissolution. ${ }^{27}$ He had been renting them before the surrender, and so it is highly likely that he was merely protecting his own interests.

Cromwell's visitations were carried out, and the first to be eliminated were the smaller monasteries with twelve or fewer inmates and annual revenues of $£ 200$ or less. The first few lines of the Act of 1536 (27 Henry VIII, c. 28) were crafted to leave no doubt that the purpose for the eliminations was to "reform" a monastic system that had gone terribly wrong:

Forasmuch as manifest sin, vicious, carnal, and abominable living is daily used and committed among the little and small abbeys, priories, and other religious houses of monks, canons, and nuns, where the congregation of such religious persons is under the number of twelve persons, whereby the governors of such religious houses and their convent spoil, destroy, consume, and utterly waste. ${ }^{28}$

Shrouded by this tirade was Henry's real intent, which was to confiscate monastic property in order to spite Rome and fill his empty coffers. Because its annual revenues and population threshold were above the set limits, Barking was spared in

\footnotetext{
${ }^{26}$ L\&P, vol. 9, no. 487; Thomas Wright, ed., Three Chapters of Letters relating to the Suppression of the Monasteries (London: John Bowyer Nichols and Son, 1843), 74-5.

${ }^{27}$ Sturman, 457.

${ }^{28}$ The Statutes of the Realm, [hereafter SR], vol. 3, MDCCCXVII (London: Dawsons of Pall Mall, reprinted,1963), 575.
} 
the early suppressions, which were completed in 1537 . Loftus and Chettle refer to the period after the first suppressions as "a troubled pause." 29 But because the Act of 1536 went on to describe the large monasteries as place[s] "wherein (thanks be to God) religion is right well kept and observed," it could just as easily have appeared to Dorothy Barley and her nuns that the worst was over and they were safe - at least for the time being. ${ }^{30}$

Unfortunately, the visitation records (comperta) prepared by the commissioners for Essex, Thomas Lee and John Ap Rice, have not survived. ${ }^{31}$ It is, therefore, difficult to surmise what they found at Barking, and whether or not the nuns would have had reason to fear for their futures. ${ }^{32}$ One cannot help but wonder if it were money Henry sought, why he did not head straight for the larger, wealthier monasteries and abbeys first. No doubt it was more politically savvy of Cromwell to dissolve the smaller monasteries first, for the nuns inside them were generally not from England's elite. A more pronounced public outrage by those whose political support Henry sorely needed might have ensued had the wealthier houses been attacked first. But perhaps the Crown had also become accustomed to milking the larger houses for assets in the form of fines and supplies:

In 1512-15 the abbess [of Barking] gave timber for building Henry's new battleship, the Henri Grace a Dieu or Great Harry. In January, 1514, she was fined $£ 100$ for offences (of which two Abbots also were found guilty) in respect of weights and measures.

\footnotetext{
${ }^{29}$ Loftus and Chettle, 50.

${ }^{30}$ Ibid.

${ }^{31} \mathrm{VCH}, 91$.

${ }^{32}$ Loftus and Chettle tell us "visitors" did come to Barking and were paid $£ 4$ each, though Lee himself may never have gone there (p. 51); Sturman argues Lee did in fact go to Barking, citing evidence from the Public Record Office (p. 419).
} 
[Additionally], her annual contribution to the cost of the French war was fixed in 1522 at $£ 3336 s .8 d .^{33}$

Like Barking, Shaftesbury Abbey felt the pinch as well. In 1527, the abbey was required to contribute $£ 1,000$ toward the king's endeavors in France. This was the same amount required of Glastonbury Abbey, and up to ten times the amount required of smaller monasteries such as Salisbury and Sherborne. ${ }^{34}$ England's monarchs, in fact, had a long history of financially exploiting the monasteries in several ways. One example that lasted until the fourteenth century gave the king the right to profit from abbess vacancies. Because the king was Barking's patron, and his permission was required to elect a new abbess, he frequently took advantage of vacancies by extending them and taking the abbey's revenues into the Crown's treasury in the interim until a new abbess had been approved and elected. ${ }^{35}$ The king also used the abbey as a prison for the wives of his enemies, and sent favorites to live in retirement as corrodies - all at the abbey's expense. With resources like this, it is no wonder the wealthier houses were initially spared. If they had been the first to go, the Crown would have effectively cut off its nose to spite its face. ${ }^{36}$

\footnotetext{
${ }^{33}$ Loftus and Chettle, 51.

${ }^{34} L \& P$, vol. 3, pt. 2, no. 2438. Barking Abbey also paid $£ 333$ 6s. 8d. toward the king's endeavors in France; Bettey, 4; Laura Sydenham, Shaftesbury and its Abbey (The Oakwood Press, 1959, reprinted, 1978), 62.

${ }^{35}$ Sturman, 378-81.

${ }^{36}$ Since the monarchs had been accustomed to exploiting the monasteries for money, it is logical that Henry turned to them when he needed to raise cash. Cromwell also knew, through his work under Wolsey, that the monasteries could provide quick and ample resources, though his end game doubtless had more to do with religious reform. It seems Henry had not thought far enough into the future to realize that once the monasteries were suppressed, they would cease to be the cash cows on which he relied. Cromwell was cognizant of this, but it did not matter because his ultimate plan was not only about money, but more importantly to rid England of Catholic allegiance to Rome in any way possible, and to instigate Protestant reform in its place.
} 
The greater houses were not spared for long, however, for in August 1536 auditors from Henry's Court of Augmentations began surveying them. ${ }^{37}$ After the statutory removal of the smaller houses was completed, the king's commissioners began their new visitations of the remaining monasteries and abbeys to elicit what became known as "induced" surrenders. ${ }^{38}$ These represented nothing more than the government's using strong-arm tactics to coerce the remaining monasteries and abbeys into "voluntary" surrender, for these were houses that had been exempt from statutory abolition under the Act of 1536. Henry's commissioners were clearly acting outside the law at this point. Many houses yielded to the pressure. So many had surrendered that the king's lawyers became concerned about his legal right to monastic property without parliamentary assent. ${ }^{39}$ Therefore, parliament, in its first session of 1539 , enacted 31 Henry VIII, wherein chapter 13 of the statute dissolved the remaining monasteries and abbeys. ${ }^{40}$ However, it did so in a completely different tone - there was no mention of reform as in the 1536 statute. In fact, there was no mention of a reason at all. This Act represented nothing more than a validation of Henry's legal right to monastic property for those houses already dissolved (since 1537) and those that may be so in the future. ${ }^{41}$

So, when the auditors for the "Court of Augmentations of the Revenues of the King's Crown" called, Barking's abbess and nuns should have had no

\footnotetext{
${ }^{37}$ Loftus and Chettle, 51.

${ }^{38}$ Youings, 81.

${ }^{39} \mathrm{Ibid}$.

${ }^{40} S R$. vol. III, 733-9; Youings, 81, 191-4.

${ }^{41} S R$. vol. III, 733-9; Youings, 81, 191-4.
} 
misconception about what was to happen, because the Crown had created the department specifically to supervise the monastic surrenders. ${ }^{42}$ Moreover, its choice of title alone should have erased all doubt that the real reason for the dissolutions was financial. Many houses had fallen in $1537-8$, and though we have no record of Dorothy Barley's personal thoughts or actions on the matter, she may have reacted similarly to many abbesses who refused to go down without a fight. The abbess at Shaftesbury was defiant and tried to bribe the king with 100 marks and Cromwell with $£ 100$ to save her house. ${ }^{43}$ Likewise, the abbess Katharine Bulkeley of Godstow Abbey, one of the wealthiest post-Conquest houses, corresponded with Cromwell several times throughout 1538 , refusing to give up her house to the commissioner, Dr. London. In November, she was granted a stay, though the house eventually fell the next year. ${ }^{44}$ The abbess at Wilton resisted and then gave up only when she had secured a hefty pension for herself ( $£ 100)$, a house at Fovant with orchards, gardens, and three acres of meadow and pasture, and a weekly load of wood. ${ }^{45} \mathrm{Her}$ shrewdness in the face of great pressure secured for her a relatively comfortable post-dissolution life. Joyce Youings recounts additional instances, stating that apart from the "heroism or obstinacy" on the part of many abbots, some of the stiffest resistance came from female heads of houses. ${ }^{46}$ Desperate times clearly called for desperate measures.

\footnotetext{
${ }^{42}$ G. W. O. Woodward, The Dissolution of the Monasteries (New York: Walker and Company, 1967), 26.

${ }^{43} L \& P$, vol. 13 , pt. 2 , no. 1092.

${ }^{44} \mathrm{Ibid}$, vol. 13 , pt. 1, nos. $441,492,1262$; pt. 2 , nos. 758,911 .

${ }^{45}$ Ibid, vol. 14, pt. 1, no. 597.

${ }^{46}$ Youings, 80-1.
} 
Many abbots and abbesses, including Barking's, also made large-scale attempts to save their communities by isolating their assets through the granting of long-term leases and property sales. They had begun to sell their valuables, presumably to protect them or to get quick cash for "insurance" against dissolution. ${ }^{47}$ During the period 1536-8, however, they had succeeded in granting so many leases that the government became suspicious and by act of parliament rendered all leases made during the previous year null and void. ${ }^{48}$ All of the leases for Barking's manors were for extended periods (most often twenty-one years and sometimes lifetime) and included the land and all the rights to grazing. The nuns were clearly trying to tie everything up in order to protect them from an uncertain future. ${ }^{49}$

In March 1538, Cromwell wrote to an unnamed abbot trying to quell fears of further suppressions by reassuring him that

you received the King's letters signifying to you that if you used yourselves as faithful subjects, he would not in any wise interrupt your mode of living, and that if any man declared anything to the contrary, you should cause him to be apprehended. Yet the King, knowing that fear may enter upon a contrary appearance where the ground is not known ... has directed me to write that unless overtures had been made by the houses that have resigned, he would never have received them. He does not intend in any way to trouble you or devise for the suppression of any religious house that standeth, except they shall desire it themselves ... You may be sure you shall not be impereched [imperished?] by his Majesty, but his Grace will be your shield and defence against all others. If any man says anything to the contrary, apprehend him, or if that cannot be done, send his name to the King. ${ }^{50}$

\footnotetext{
${ }^{47}$ Youings, 58.

${ }^{48} S R$, vol. 3,735 .

${ }^{49}$ Sturman, 427-9.

${ }^{50} L \& P$, vol. 13, pt. 1, no. 573 .
} 
Though the letter sounds comforting, Cromwell's real motivation may have been to stop the sales and reallocations of monastic valuables, keeping them in place for later confiscation. This had been hinted at in a January letter from Richard Layton, one of Cromwell's commissioners responsible for carrying out the suppressions, wherein he reported that gossip about the suppressions was rampant and had prompted the abbots and abbesses to sell off goods. He, too, reassures the heads of the monasteries that "they should not, for any such vain babbling of the people, waste, sell, grant or alienate any of their property." ${ }^{, 51}$ Cromwell, seeing the risk of losing so many monastic spoils, probably crafted his letter as a pre-emptive strike against further similar actions on behalf of frightened religious. Unfortunately for the nuns at Barking Abbey, their efforts to ensure their future were for naught, and their lives were forever altered with the surrender in late 1539.

While Henry's policies and Cromwell's tenacity were the driving force behind the elimination of the monasteries, some scholars suggest there were other forces at work that may have had a hand in their demise as well. Desilets argues that changing attitudes toward women and their roles in society also had an impact on the female religious and their destinies both pre- and post-dissolution. The ideals of the Renaissance created a shift in focus from the heavenly to the earthly. A sort of oneness with God was now possible for anyone simply through enjoyment of nature and the beauty present on earth. This shift in ideology made nuns, who had been considered special specifically because they had shunned earthly concerns, less

${ }^{51} L \& P$, vol. 13 , pt. 1, no. 102. 
exalted. Female beauty, the pleasures of love, and the promotion of marriage superseded the benefits of the celibate life. ${ }^{52}$ This emphasis on the secular life and a woman's role as wife and mother made things even more difficult for nuns after the suppression, for though Henry's Act of Six Articles (1539) prohibited the marriage of priests, more importantly for our discussion here it included a statute precluding any person (male or female) who had professed at age twenty-one or older from marrying, unless they could prove they had been forced or otherwise coerced into taking their religious vows. ${ }^{53}$ Since many of the nuns from Barking Abbey (particularly widows) had professed later in their lives, this Act put them in the position of being somewhere and nowhere. They could no longer serve their community as they had before, and yet they were forbidden to become the type of women society now valued.

Likewise, Hoyle argues that in the fifteenth and sixteenth centuries attitudes toward monasteries changed. Monasteries were "purgatorial institutions" wherein a founder or benefactor could be guaranteed prayers and masses for their family's souls. With changing economic climates, fewer people had the money to endow a monastery for such a function, and so the practice fell out of vogue. He also points out that for those who did have the means, new options such as colleges and almshouses (that were less expensive to maintain) became fashionable. ${ }^{54}$ Furthermore, by the fifteenth century, society had begun to view the prayers said by

\footnotetext{
${ }^{52}$ Desilets, 18.

53 Youings, 81 .

${ }^{54}$ Hoyle, 276-7.
} 
monks and nuns as less important or valuable than those said by priests, hence the growing popularity of chantries. ${ }^{55}$ Benjamin Thompson also claims that in the years leading up to the dissolution, the monasteries had outgrown their original purpose and usefulness and had become relics of the past. He suggests that the monasteries were so ripe for reform and at risk of jeopardizing their own future, that the dissolution and Henry's politics were just fortuitous events that ended monastic life a little sooner than it would have otherwise ended itself. ${ }^{56}$

These observations about the validity of the nunnery beg the question, if Henry had never dissolved the monasteries, would they have been doomed to obsolescence by shifting cultural or social sands? It seems fair to argue they would not have entirely disappeared from the landscape due to the other vital community services they provided such as the education, employment, and charity previously mentioned. Benjamin Thompson concedes that by the dissolution, the only thing keeping the monasteries viable in early-modern society was the number of social services they offered, stating that "[monasticism] retained support because it satisfied a range of different needs. ${ }^{357}$ He goes on to say that because of the social services monasteries provided, "many houses were removed which might otherwise have survived, some of the greater houses and the nunneries prominent among them.."58 Barking Abbey certainly fits into this group. The abbey's life was closely linked to those it served throughout the county and to those who served the abbey in return.

\footnotetext{
${ }^{55}$ I owe this point to Dr. Caroline Litzenberger.

${ }^{56} \mathrm{~B}$. Thompson, 165-95.

${ }^{57} \mathrm{Ibid}, 169$.

${ }^{58}$ Ibid, 192.
} 
As Sturman points out, the nuns' surnames betray age-old relationships whereby daughters were sent to live in the abbey, fathers worked in the administration of the abbey's estates, and families remembered the abbey in their wills. ${ }^{59}$ The bonds were tight and continual; the services offered by the abbey were vital components in the survival of both the abbey and its larger community. Furthermore, nunneries such as Barking were to a huge degree self-sufficient, and if they disappeared, the onus might have been put on the State to provide the services lost through their elimination. In other words, it might have been easier, cheaper, and politically more expedient just to let them survive as social service institutions. Even Hoyle had to admit the act of providing aid and hospitality alone was still valued by enough of society that it could have justified the nunneries' survival. ${ }^{60}$

It does seem possible that had the Church not been one of the largest land holders in England, the monasteries might have been left alone. By the late-1530s, Henry, a traditional Christian his entire life, began to have second thoughts about the extent of Cromwell's reform plans. In 1539, Henry officially rolled back some of the reforms with the Act of Six Articles, which returned the Church of England to a former, more conservative version of itself. But by then, most of the monasteries had fallen, their assets liquidated to benefit the Crown. For Henry, the driving forces were not religious reform or the fact that the monasteries were no longer important to society, but quite simply his need for cash that made the rich Church a prime target.

\footnotetext{
${ }^{59}$ Sturman, 402.

${ }^{60}$ Hoyle, 277.
} 
Had the monasteries not been able to provide Henry with substantial cash quickly, they might have survived.

As far as the dissolution's effect on those who depended on the abbey for their livelihood goes, evidence exists showing at least some of them received payments in the form of pensions, annuities, fees, or corrodies. The Court of Augmentations made the disbursements, and those connected with Barking Abbey fared well capturing just over $£ 50$ of the total $£ 191$ paid out to members of all the religious houses in Essex. ${ }^{61}$ The abbey buildings were not so fortunate. On June 19, 1541 , work commenced "by his graces commandement in undermynding \& casting downe the late Abbey Chyrche of Barking, for the providing of the fayrest coyne stones \& other to be ymployed of the Kings man." This work of stripping and pillaging for reuse at the king's pleasure continued until its completion in December 1542. Henry granted the abbey lands and manors to various favorites, and the abbey site and demesne lands to Thomas Wriothesley, Earl of Southampton, for life. Interestingly, Wriothesley also benefited from the suppression of Shaftesbury Abbey, for in 1547 he was granted the abbey site and lands there as well. ${ }^{62}$ After the Earl's death in 1550, Edward VI granted Barking Abbey's site and demesne lands to Edward Lord Clinton in May 1552. ${ }^{63}$ The valuables stripped from the abbey were substantial. There were huge quantities of lead and bell metal (Barking had eleven bells), in addition to the jewels, silver vessels, silver gilt, parcel gilt, pure silver,

\footnotetext{
${ }^{61}$ Sturman, 450.

${ }^{62}$ Bettey, 8; Sydenham, 69.

${ }^{63}$ Clapham, 72-3.
} 
copes, gold vestments, and a monstrance (the utensil used for presenting the consecrated host to the congregation) weighing sixty-five ounces. ${ }^{64}$ There were also "divers goods, grain and cattle" that were recorded in 1540 as having been sold for just over $£ 182 .^{65}$ The value the Crown continued to place on these items (and those confiscated from monasteries throughout the land) became evident in 1552 . On December 12th, Edward VI commissioned no fewer than eleven high-ranking officials (Edward Lord Clinton among them) to inquire into the whereabouts of large amounts of monastic property, which had "since the beginning of [his] reign been carried beyond sea without licence." They were given the authority to find out where it went, who sold it, how much they were paid for it, and to proceed toward restitution to the king. ${ }^{66}$ In the end, the Crown and its favorites had all looked upon the dissolutions and monastic spoils in the same light - like pigs to the trough.

Once the dissolution process began, some of the nuns from the more impoverished, small houses no doubt fell through a huge societal crack and ended up beggars or worse, especially since the granting of pensions below the level of abbess did not become official policy until $1537 .^{67}$ The pension amounts for Barking's nuns were calculated by Sir William Petre (the commissioner who accepted the house's surrender), who no doubt considered the abbey's relative wealth and his friendship

\footnotetext{
${ }^{64}$ Sir John Williams, Late Master and Treasurer of the Jewels to His Majesty King Henry VIII, Account of the Monastic Treasures Confiscated at the Dissolution of the Various Houses in England (Edinburgh: The Edinburgh Printing Co., 1836), 30; Francis Aidan Cardinal Gasquet, Henry VIII and the English Monasteries (London: John C. Nimmo, 1899), 307-8; Locks, 48; Oxley, 255-6; Sturman, 453.

${ }^{65} \mathrm{VCH}, 120$.

${ }^{66}$ CPR, Edward VI, 1550-53, vol. 4, 391.

${ }^{67}$ Hoyle, 62
} 
with the abbess, Dorothy Barley, when making his estimations. He had been directly involved in the visit of 1535 , and so knew firsthand the abbey's economic status. ${ }^{68}$ He was also closely associated with some of the women at Barking, for he had married Gertrude Tyrell, whose sister Mary Tyrell was one of the last nuns. And, as previously mentioned Dorothy Barley was a family friend and godmother to his second child, a girl he named Dorothy, presumably after the abbess. ${ }^{69}$ The abbey had also gained Petre's favor in early 1538 by granting him a $£ 10$ annuity from their estates, and this may have had additional influence on the generous pensions granted, particularly to Dorothy Barley. ${ }^{70}$ This strategy was also undertaken at Shaftesbury, where the abbess granted Sir Thomas Arundell an annual stipend of $£ 12$. Arundell was also one of Cromwell's commissioners and, like Petre, was the man who ultimately accepted Shaftesbury's surrender. ${ }^{71}$ Also influential could have been the ease with which Dorothy surrendered the abbey; generous pensions were the "carrot" for smooth surrenders, whereas withholding of pensions was the "stick" for those who resisted. ${ }^{72}$

According to Youings, in the second round of suppressions the Crown felt more obligated to provide some sort of living or accommodation for the displaced religious primarily because they were concerned not to make martyrs of them. This might have been a very real possibility, for in many cases the larger, wealthier

\footnotetext{
${ }^{68}$ Sturman, 433.

${ }^{69}$ Ibid, 420.

${ }^{70} \mathrm{Ibid}, 426,440$.

${ }^{71}$ Bettey, 6; Sydenham, 64.

${ }^{72}$ Desilets, 328.
} 
houses that fell during the second phase were populated with many men and women who were related to influential laymen in Henry's court. ${ }^{73}$ The nuns at Barking fared better than most, receiving lifetime annual pensions from the Crown, with the abbess receiving the highest payment of $£ 1336 s .8 d^{74}$ Thomasina Jenney, the prioress, received $f 1613 s .4 d$, and her sub-prioress Margaret Scrope was given a pension of $£ 8$. Three additional officers were each given $£ 613 s .4 d$. The remaining pensions were split between the more senior women receiving $£ 5-6$ each, and their juniors receiving 53s. $4 d$. Poor Alice Hyde, who was probably the youngest of all, received only $33 s .4 d .^{75}$ Oxley suggests the younger nuns were probably paid lower pensions because they had a better chance of marriage after the dissolution, which seems plausible. As previously mentioned, we do know this was the case for at least one of them; Winifred Mordaunt married John Cheney of Buckinghamshire in the fall of 1541. ${ }^{76}$ Her pension had been among the smallest at $53 s .4 d .^{77}$

The Victoria County History of Essex indicates the majority of the nuns were still alive and receiving their pensions during Mary's reign. ${ }^{78}$ Though Mary was a staunch Catholic and worked throughout her short reign to return England to its former Catholic glory, she continued to pay monastic pensions instead of restoring the monasteries. Restoring the monasteries would have been difficult because by the time Mary ascended to the throne in 1553, many monastic buildings had been torn

\footnotetext{
${ }^{73}$ Youings, 49.

${ }_{74} \mathrm{Ibid}, 352$; Oxley, 238.

${ }^{75}$ Sturman, 439.

${ }^{76}$ Castelli, "Mordaunt Family," Oxley, 239.

${ }^{77}$ Desilets, 417-18; Oxley, 238.

${ }^{78} \mathrm{VCH}, 120$.
} 
down and assets sold off, much of it to elite Englishmen serving in parliament whom Mary could not afford to alienate. ${ }^{79}$ She did, however, try in March 1555 to return abbey lands and possessions held by the Crown to the Pope. She refused to keep them for herself over the objections of her councilors (based on the grounds that the Crown needed the resources in reserve), stating that "notwithstanding I set more by the salvation of my soule than by [ten] kingdomes." Pope Julius III issued a Bull of Excommunication for anyone harboring monastic lands or possessions, but the nobles ignored the bull and convinced the public that the Pope's decree was directed at other countries, not England. Because the nobles were so powerful, the Pope's clergy in England never pursued the matter and Julius died shortly thereafter, leaving the issue unresolved and the abbey's lands and possessions securely in the Crown's coffers. ${ }^{80}$ The monastic pension roll under Mary (1555-6) shows payments to Dorothy Barley and twenty-one nuns. ${ }^{81}$ However, though they remained on the dole, we can assume that many of the nuns' lives were in no way as comfortable as they had been inside the abbey, if for no other reason than the loss of sisterhood, which meant loss of the shared resources inherent in communal living. This would have been especially true for the elderly nuns who possibly had no secular family left to turn to but needed the assistance in their old age that their sisters at Barking would have supplied.

\footnotetext{
${ }^{79} \mathrm{I}$ owe this point to Dr. Caroline Litzenberger.

${ }^{80} \mathrm{John}$ Foxe, Actes and Monuments, $4^{\text {th }}$ ed. (London: John Daye, 1583), 1559-60.

${ }^{81}$ Loftus and Chettle, 52.
} 
When Dorothy Barley surrendered the abbey in 1539 , thirty nuns were in residence with her. She had been abbess since 1527 and had been at Barking for twenty-one years; she was forty-nine years old. Sturman estimates that perhaps half of the remaining nuns were likewise middle aged. ${ }^{82}$ The dissolution must have been especially hard on these women who had been professed for so many years, because they virtually knew no other way of life. Sturman also points out that, especially for the nuns with lower pensions, the fixed annual payments were problematic because they never increased (did not keep up with wages) and were subject to heavy taxation. ${ }^{83}$ Geoffrey Baskerville points out that after the dissolution many male monks received paying benefices while continuing to receive their pensions, in effect doubling their income. ${ }^{84}$ This option was never available to nuns. Though we do not know with certainty what happened to every one of the nuns, these financial burdens managed to push some of them back into their secular families for support. Because most of the inmates had come from the surrounding elite and gentry-class families, who were also abbey patrons, it is likely, as Claire Cross argues in her study of Yorkshire nuns, that those families did not turn their backs on them just when they needed them most. ${ }^{85}$ As mentioned in chapter two of this thesis, we do have evidence that Margery Paston returned to life with her father, Sir William Paston, and Gabrielle Shelton likewise returned to life with her father, Sir John Shelton. ${ }^{86}$

\footnotetext{
${ }^{82}$ Oxley, 437.

${ }^{83}$ Sturman, 442.

${ }_{85}^{84}$ Baskerville, 206; Youings also makes a similar point, see pp. 62-3.

${ }^{85}$ Cross, 314.

${ }^{86}$ Sturman, 444-5
} 
Both women were still receiving pension payments in $1555 .^{87}$ Information included in wills also suggests Mary Tyrell returned to her father's home, and Margaret Scrope may have gone to live with her sister. ${ }^{88}$ Although back in the relative safety of their family homes, it nevertheless must have been incredibly wrenching and difficult for them to be separated from the sisters who had in effect become their family, for some of them over the course of decades.

We are not certain if any of the others tried to stay together. However, there may be evidence that Dorothy Barley was at least close to some of her fellow nuns until her death. Her will, proved in 1559 , states

Item I bequeath to my Coussin Ursula wentworth somtymes a Nonne of Barking a tablet of mother of Pearle enclosing ii Images of sylver and gylt.

Item I bequeath to Mistris Suzan Sulyard somtyme Nun of Barking a towel of diaper and vi s. viii d. in money.

Item I bequeath to Mistris Margery Ballarde somtyme Nun of Barking one payre of sheets of flex with a diaper towel, a fine Raylle and vi s. viii d. in money. ${ }^{89}$

All three of these women were among the last nuns at the dissolution, and according to Sturman, they appear with fellow nuns Martha Fabyan and Agnes Horsey in Cardinal Pole's 1556 survey as still in receipt of their pensions. They, therefore, were the oldest surviving Barking Abbey nuns. ${ }^{90}$

\footnotetext{
${ }_{87}^{87}$ Cunich, "Monastic Database for England and Wales in the Sixteenth Century."

${ }^{88}$ Sturman, 444-5.

${ }^{89}$ The Will of Dorothy Barley, the last abbess, 1556, printed in Sturman, appendix III.

${ }^{90}$ Sturman, 447.
} 
Though we do not know for sure if they were living together, Dorothy's large pension certainly could have made this arrangement affordable. The vast majority of ex-nuns were probably not so fortunate. In fact, according to Joan Greatrex in her article on Benedictine nuns in Winchester diocese, sufficient evidence exists that nuns from Nunnaminster and Wherwell Abbeys did remain together, but they may have been some of the only Benedictine nuns to have continued some type of formal communal life. ${ }^{91}$ It is unfortunate that these few fragments may be all we shall ever know about the personal lives of the women who were nuns at Barking Abbey. Unfortunately, it appears most of the evidence concerning the more intimate aspects of their lives after the dissolution, if it ever existed, has not survived or has yet to be uncovered.

A few historians, such as Peter Cunich and Donald Logan, have recently raised questions regarding whether or not nuns were relieved to be freed from their vows and the extent of the trauma nuns experienced as a result of the dissolution. ${ }^{92}$ Of course, as mentioned above, absent evidence from the Barking Abbey nuns these are difficult questions to answer with any certainty. Cromwell's policy during the early visitations in 1535 was to allow monks and nuns to be freed from their vows, if they so desired, only if they were under age twenty-four. By October 1535 , that

\footnotetext{
91 Joan Greatrex, "On Ministering to 'Certayne Devoute and Religiouse Women': Bishop Fox and the Benedictine Nuns of Winchester Diocese on the Eve of the Dissolution," in Women in the Church, Studies in Church History, vol. 27 (Oxford: Basil Blackwell, 1990), 235.

${ }^{92}$ Peter Cunich, "The Ex-Religious in Post-Dissolution Society: Symptoms of Post-Traumatic Stress Disorder?' in The Religious Orders in Pre-Reformation England. James G. Clark, ed. (Woodbridge, England: The Boydell Press, 2002), 227-38; F. Donald Logan, "Departure from the Religious Life During the Royal Visitation of the Monasteries, 1535-1536," in The Religious Orders in Pre-

Reformation England. James G. Clark, ed. (Woodbridge, England: The Boydell Press, 2002), 213-26.
} 
policy had shifted to allow for the expulsion of all under age twenty, and to allow those between ages twenty and twenty-four to make the choice for themselves. ${ }^{93}$ As Logan points out, the choice to leave was a very personal decision, for no distinctive pattern emerges among those who left. And more importantly, for those monks and nuns for whom we have records, few actually chose to leave. ${ }^{94}$ It is possible to surmise that the nuns present at Barking Abbey's dissolution were similarly dedicated to their religious life and not eager to be freed from their vows, since by the time Cromwell's commissioners visited Barking in 1536, the policy had once again shifted, and all monks and nuns, regardless of age, were given the opportunity to be released from their vows. Clearly, those women present at the dissolution three years later had chosen not to accept Cromwell's offer, possibly indicating their desire to continue monastic life.

It is possible to speculate, based on both Eamon Duffy's and Caroline Litzenberger's assertions that traditional religion was alive and well in England until long after the dissolution, that once returned to their secular lives, some of the former nuns continued to practice a "morphed" version of Catholicism, as many former nuns did. ${ }^{95}$ Dorothy Barley did not go far after the dissolution, retiring to the Essex parish of Weald (as is indicated in her will), where it is assumed her faith continued to be traditionally Catholic. Evidence that Dorothy had not converted to Protestantism is

\footnotetext{
${ }_{93}^{93}$ Logan, "Departure," 214-17.

${ }^{94} \mathrm{Ibid}, 219-22$.

${ }^{95}$ Cross, "The Religious Life of Women," 316-17; Duffy, Stripping of the Altars, particularly Section I; Caroline Litzenberger, The English Reformation and the Laity: Gloucestershire, 1540-1580

(Cambridge: University Press, 1997).
} 
found in the will's preamble, in which she invokes the names of "the father, the Sonne, and the holly ghoste, thre persons and one God in Trynitie," and bequeaths her soul to "Allmightie god my Creator and redeemer," for followers of the traditional religion used these "ambiguous" terms in preambles, rather than more obviously Protestant terms, long after the Reformation. ${ }^{96}$ Some of the other nuns could have easily joined the ranks of secular, "closeted" Catholic women in the preservation of their faith. As Frances Dolan points out, the dissolution of the monasteries changed how devotional spaces were perceived and used because so many former monasteries had become secular dwellings or ruins. As such, the usual ornamentation and apparatus were driven underground into domestic spaces, which were primarily controlled and sustained by women. ${ }^{97}$ For the Barking Abbey nuns this would have been crucial for continuing their devotions because, as mentioned above, the abbey had been completely destroyed by December 1542; there was no "devotional space" to return to even if they had wanted to. Therefore, their only options would have been to accept Protestant life or to adapt to the new world order by limiting their Catholic devotions to their secular homes, and to the most personal space of all - their own hearts.

\footnotetext{
${ }^{96}$ Litzenberger, passim, but particularly Appendix A, Table A.1, p. 172.

${ }^{97}$ Frances E. Dolan, "Gender and the 'Lost' Spaces of Catholicism," Journal of Interdisciplinary History, 32:4 (Spring 2002), 644.
} 
CONCLUSION

In the patriarchal society that was England in the mid-sixteenth century, the suppression of Barking Abbey undoubtedly resulted in fewer respectable options for its nuns. Through the dissolution, the State had effectively eliminated one of the few arenas where women were afforded some semblance of autonomy. For a woman of the aristocratic or landed gentry class, as so many of Barking's nuns were, the opportunity to hold high-level positions of responsibility and authority existed primarily within convent walls. In a society steeped in group identity, the monastery was fundamental to the nuns' self-image. It was through their relationship with their fellow sisters and the abbey community at large that religious women secured their identity. The abbey also provided them with opportunities to be vital members of their community through the employment and supervision of laymen and women, education, and performance of charitable acts such as almsgiving and the maintenance of a hospital. With these options and responsibilities stripped away, the ways in which Barking's nuns could make meaningful contributions to their society were greatly reduced. Several male monks escaped the same fate, for they obtained benefices and continued to earn their livings through their devotion to God (while receiving pensions from the Crown!). ${ }^{98}$ This option was never a possibility for women religious. With the exception of the queen, a woman's ability to possess the level of power and influence that Barking Abbey's nuns had enjoyed over

${ }^{98}$ Baskerville, 205-6. 
themselves and members of their community for more than eight hundred years would not exist again until the twentieth century. 


\section{Chapter VI}

\section{Conclusion}

Though in theory the purpose of monastic life was to spend it dedicated to God in quiet contemplation removed from the problems of the secular world, the reality was very different. Nuns who chose or were sent to the convent ended up living lives that were at the same time monotonous and complex, boring and interesting. Their spiritually elevated positions within their larger communities did not protect or prevent them from a fairly wide range of fully human experiences. For the nuns at Barking Abbey, the daily spiritual and charitable obligations dictated by their Rule were constantly mixed with the temporal duties necessary for maintaining their community. All of these duties brought the nuns at various times in contact with patrons, guests, servants, tenants, administrators, general laborers, and even prisoners. Many of the nuns' responsibilities frequently came perilously close to infringing on their most important reasons for being: worshipping God and praying for the souls of benefactors. The nuns, therefore, were constantly caught in a struggle to balance the contemplative life of Mary with the active life of Martha.

Despite this struggle, the social provenance of the nuns at Barking may have helped to keep life inside the abbey relatively comfortable when compared to smaller, poorer nunneries, primarily because of the patronage relationships between the nuns and the king and also their secular, privileged families. The pedigrees of 
the women who chose monastic life varied across England based largely on location, and with few exceptions the larger and wealthier houses like Barking were in southern England and drew their recruits primarily from the aristocracy and local upper gentry. Nunneries elsewhere in England tended to be smaller and poorer, and were primarily the homes of daughters of nearby "middling" class families. Our study of the last thirty-one nuns at Barking indicates the women there tended toward the upper classes to the very end of the abbey's history. Barking's elite status was further betrayed by its tradition of learning and the educated women within its walls who, according to David Bell, may have continued to read and understand Latin up to the dissolution - something most English nunneries had ceased doing some two hundred years earlier. The social provenance of the Barking Abbey nuns and their patron relationships created privileges which ranged from a more varied diet to monastic survival. When in $1535-6$ the first monastic institutions began to fall, it was Barking Abbey's size, wealth, and elite status that provided a stay of execution. As a large abbey, Barking was an incredibly lively and busy place and acted as a magnet for its larger lay community. Many people relied on the services and opportunities the convent provided. Prayers and devotions were certainly the most important aspects of the nuns' lives, but the rigorous tasks involved in the daily maintenance of the household, including trading with, employing, and providing spiritual succor for local lay folk, were also vital for ensuring the convent's survival. While the nuns at Barking invariably had assistance from hired lay administrators, it remained the duty of the abbess, prioress, and nuns themselves to see that the 
necessary food was grown or purchased, the vestments and church ornaments were produced and maintained, the rents were collected, miscellaneous supplies were acquired as necessary, and their obligations to aid the sick and poor were met. The nuns were also responsible for their employees and servants, and therefore had to include effective human resource management in the skills required for a smoothrunning house.

Though many historians of women's monasticism have argued that opportunities for responsibility and authority were greater inside than outside the convent, few have been able to determine successfully from the sources how the nuns themselves felt about those opportunities. Since Barking Abbey followed the Benedictine Rule, which required work and self-sustenance, it is probable the nuns merely felt their administrative responsibilities fulfilled a duty to their Rule. They probably also realized the most practical reason for efficient monastery management: without it the house would likely cease to exist. Spiritually, the nuns also knew that keeping the house intact for their successors meant that future sisters would be able to pray for their souls after they had died. The entire point of maintaining the household was not about opportunities for responsibility and advancement, but rather about sustaining and supporting the community which made the nuns' chosen lives possible.

Though the nuns' lives were focused on praying and working, they were not devoid of cultural activity. Art and cultural expression have always been important aspects of Christian worship and were so for monks and nuns as well. Large 
Benedictine abbey churches like the one at Barking were lavishly decorated to engage and draw people into the mysteries of the faith. Devotional objects and buildings were meant to arouse and instruct the faithful, both religious and lay. The abbey church represented heaven on earth, and its ornate decoration was an influential source for artistic and spiritual inspiration. Over the course of monastic history, many unnamed monks and nuns, inspired by their devotion to God and the beauty of their monastic churches, were responsible for creating and illuminating manuscripts as well as producing or commissioning other objects for use in daily devotions.

Evidence for production of art objects at Barking Abbey is slim, though recent archaeological activity at the abbey site has uncovered evidence of textile production from the abbey's Anglo-Saxon period. Since needlework was a common feature of most women's lives, both religious and secular, it is likely that textile arts continued to be practiced at some level at Barking throughout its history. Glass arts were also practiced at the abbey, though it is not certain if the nuns themselves made glass objects or if they merely acted as patrons, commissioning objects as necessary. The nuns did commission at least one painting of a saint, which was recorded in the account book of the abbey's Office of Pensions in the early-sixteenth century. Additional activities which reflected the cultural life of the abbey were processions, plays, singing, and the playing of music. The performance of these activities was meant to uplift the nuns and to express outwardly their faith and devotion to God. However, one of the most important cultural pursuits at Barking, and the one for 
which we have the most surviving evidence, is that of learning and reading. Saint Benedict stressed in his Rule the significance of daily reading as an act of devotion, and through Barking Abbey's extant manuscripts and books, and also its library's annual practice of book lending, we can surmise the continued importance of the written word in enriching the nuns' lives. Though specific evidence from the Barking nuns does not exist, it is nonetheless difficult to believe the women were incapable of appreciating and being enriched by exquisite objects, lively processions, or a beautifully sung hymn. They were, after all, humans who lived in a time that could be exceedingly brutal and harsh, which makes the seeking or recognizing of beauty seem even more natural. The nuns knew and understood Saint Benedict's mandate against owning or coveting personal property; however, as religious women they probably felt the most important purpose of art objects was to aid them in their expression of piety and their emulation of Christ's life. Creation was an act of devotion; beauty was an expression of God's presence on earth.

The unfortunate end of Barking Abbey's story brings with it the realization that even though monasteries had long provided important services for the faithful of England, none of that mattered in the heated political and religious climate of the 1530s. In less than a decade, Henry VIII and Thomas Cromwell had managed to dismantle completely a system of Christian service that was centuries old. With that system went one of the only areas where an early-modern religious woman was afforded a level of autonomy and authority that did not exist for her elsewhere. The dissolution of the monasteries effectively eliminated the nuns' ability to practice 
their faith and serve their community as they had done for centuries. Though some historians have argued that by the early-sixteenth century monasticism had run its course, the nuns at Barking Abbey and her sister institutions would not have agreed. They still would have felt themselves to be useful in Christian England and have wanted to continue in their chosen vocation, which is evident in the attempts made by many abbesses to secure their house's property through long-term leases, and to gain cash for survival by selling off monastic property. Some abbesses even offered bribes to Cromwell and the king in an attempt to secure their future. Their efforts were ultimately futile, and at Barking Abbey all of the nuns' Christian dedication expressed through prayer, charity, and work came to a halt in November 1539. The nuns' lives then took an unexpected turn into the temporal world. Many were too old to marry and for those with smaller annual pensions, merely surviving must have been a challenge. Unlike their male counterparts who could obtain benefices and continue to sustain themselves through practicing their faith, the nuns were merely swept away as unnecessary relics of the past.

Because religious women essentially became invisible by 1540 , historians of sixteenth-century England will continue to have their work cut out for them when it comes to uncovering how those women experienced monastic life and how they reacted to life outside the cloister in post-dissolution society. However, in the past thirty years, scholars have uncovered or reinterpreted a great deal of evidence which has helped to broaden the study of English nuns, and doubtless this investigation will continue for many years. Recent historiography has provided a wealth of 
information about specific aspects of the female monastic experience, but it is now time to reassemble some of those pieces into a discernable whole in order to obtain a fuller understanding of the complexities of nuns' lives as they lived them. Through the work of historians such as Marilyn Oliva, Claire Cross, and Catherine Paxton, we know something about the social provenance and lives of nuns in larger areas such as the Norwich diocese, Yorkshire, and London. This thesis could have contributed to that historiography by providing the same level of information about nuns in greater Essex. Likewise, this study could have followed the lead of historians such as Jeffrey Hamburger or Charlotte Woodford by providing detailed information about one specific aspect of monastic life. But it is important to note that by limiting the focus to the lives and human experiences in one nunnery in Essex, Barking Abbey, this study moves the discussion away from both the early, general histories and the more recent, specialized accounts to a middle ground wherein the narrative of the nuns' lives expresses itself in a more complete way.

This thesis has answered many questions, but it has also raised others. Admittedly, the personal nature of some of the questions makes it unlikely that the extant evidence will ever provide answers. Nonetheless, three broad categories of questions have emerged. First, with respect to life inside Barking Abbey, questions have arisen such as, how did the prioress maintain discipline, and by what methods or punishments did she accomplish her task? Likewise, how were internal conflicts resolved? In addition to the information about the nuns' social provenance discussed in chapter two of this thesis, it would also be helpful to know where the women fell 
within the life cycle. What was the percentage of widows, young women, or girls, and how did those percentages fluctuate over time? Was a house with mostly older women run differently from that with a majority of younger women, or was there always a mixture of ages and maturity levels that might have provided a sense of balance or stability?

The second category of questions relates to the nuns' responses in the face of their house's dissolution. Chapter five of this thesis has shown that some abbesses reacted by scrambling to sell or somehow protect monastic property, but how did they react on a personal level? Were they devastated or traumatized in any way? Or were they perhaps relieved? Also, did any of Barking Abbey's nuns ask for release from their vows in 1536 , and if so, what were their reasons? Lastly, the majority of the questions which have arisen from this study concern the nuns' lives after the dissolution. How did they react to life outside cloister walls, and how did society respond to their sudden presence among the laity? Caroline Litzenberger's research on the laity in Gloucestershire indicates that most people dug in their heels and resisted religious change. ${ }^{1}$ Once released into secular life, did the nuns also resist and continue to practice their faith, and did the east-Anglian laity support the displaced nuns with whom they shared feelings of confusion and a determination to preserve the old ways? Did nuns ever join the ranks of secular, recusant Catholic women? Many secular Catholic women were known to harbor priests; did any of those women ever provide similar protection for nuns? Inside the cloister, nuns'

\footnotetext{
' Litzenberger, The English Reformation and the Laity, passim.
} 
lives were largely based on service to the Christian community. What role or service did, or could, they provide in secular society after the dissolution?

While some of the questions above require studying the thoughts and actions of laymen and women, both before and long after the dissolution of the monasteries, many could be answered through the exploration of individual nunneries and the range of the inmates' experiences, sacred and profane. It is unfortunate that such a paucity of evidence exists for Barking Abbey which could help provide answers to these questions. However, where records for other English nunneries do survive, it is important that scholars seize the opportunity to use them to provide a clearer view of life inside those particular institutions. Once historians fully explore the lives and experiences of women in other specific nunneries, both pre- and post-dissolution, those nuns and their houses can then be placed within the wider context of English women's monasticism and English society as a whole, creating a more complete, indeed human, picture. 


\section{BIBLIOGRAPHY}

\section{Manuscript Sources}

Public Record Office, London

E $101 / 458 / 7$

Abbey of Barking Expenses of repairs there, etc.

SC 6 Hen. VIIL/928 Barking abbey book of receipts and payments (Office of Pensions)

SC 6 Hen. VIII/929 Barking abbey book of accounts of the cellaress

\section{Printed Primary Sources}

Calendar of Entries in the Papal Registers relating to Great Britain and Ireland. Papal Letters, Vol. V, A.D. 1396-1404. W. H. Bliss and J. A. Twemlow, preparators. London: Mackie and Co. Ld., 1904.

Calendar of Patent Rolls Preserved in the Public Record Office, Edward VI, 155053. Vol. 4. London: Published by His Majesty's Stationery Office, 1926.

Domesday Book. Vol. 32, Essex, edited by Alexander Rumble. Chichester: Phillimore, 1983.

Foxe, John. Actes and Monuments. 3 vols. $4^{\text {th }}$ edition. London: John Daye, 1583.

Here begynneth the Rule of seynt Benet: Richard Fox's translation of the Benedictine Rule for women, 1517, printed in Female Monastic Life in Early Tudor England, Barry Collett, editor. Burlington, VT: Ashgate Publishing, 2002.

Letters and Papers, Foreign and Domestic, of the reign of Henry VIII, 21 vols., James Gairdner and R. H. Brodie, editors. London: Kraus Reprint Ltd., 1965.

Martyn, Roger. The State of Melford Church as I, Roger Martyn, Did Know It, printed in Religion \& Society in Early Modern England: A Sourcebook, David Cressy and Lori Anne Ferrell, editors. London and New York: Routledge, 1996, reprinted 2001. 
The Regiser of Archbishop Johannis Peckham, (Rolls series) vol. 1, pp. 81-86, in The Victoria History of the County of Essex. Victoria History of the Counties of England, Vol. 2. W. Raymond Powell, H. A. Doubleday, Wm. Page, and John H. Round, editors. Folkestone: Published for the University of London, Institute of Historical Research by Dawsons, 1977-.

The Charthe longynge to the Office of Celeresse of the Monasterye of Barkinge. In Monasticon Anglicanum, vol. 1. pp. 80-3. Translated by Sir William Dugdale. London: 1693.

The Early Charters of Barking Abbey. Translated by Cyril Hart. Colchester: Benham and Company Limited, 1953.

The Letters of John of Salisbury Vol. 1, The Early Letters (1153-1161), W.J. Millor, S. J. and H. E. Butler, editors, revised by C. N. L. Brooke. Oxford: Clarendon Press, 1986.

The Ordinale and Customary of the Benedictine Nuns of Barking Abbey, 2 Vols. University College, Oxford, MS. 169. J. B. L. Tolhurst, editor. London: Henry Bradshaw Society, 1927.

The Paston Letters. Norman Davis, editor. New York: Oxford University Press, 1983.

The Statutes of the Realm. Vol. 3. London: Dawsons of Pall Mall, 1817, reprinted 1963.

The Venerable Bede. The Ecclesiastical History of the English Nation. London: J. M. Dent \& Sons, Ltd., 1951.

The Will of Dorothy Barley, the last abbess, 1556. In Winifrid M. Sturman, "Barking Abbey: A Study in its external and internal administration from the Conquest to the Dissolution.” Ph.D. diss., University of London, 1961. Appendix III.

Williams, Sir John, Late Master and Treasurer of the Jewels to His Majesty King Henry VIII. Account of the Monastic Treasures Confiscated at the Dissolution of the Various Houses in England. Edinburgh: The Edinburgh Printing Co., 1836. 
Secondary Sources

Baskerville, Geoffrey. "Married Clergy and Pensioned Religious in Norwich Diocese, 1555, Part II." English Historical Review 48 (January 1933): 199228.

Beach, Alison I. "Voices from a Distant Land: Fragments of a Twelfth-Century Nuns' Letter Collection." Speculum 77 (2002): 34-55.

Bell, David N. What Nuns Read: Books and Libraries in Medieval English Nunneries. Kalamazoo: Cistercian Publications, Inc., 1995.

Bell, Susan Groag. "Medieval Women Book Owners: Arbiters of Lay Piety and Ambassadors of Culture," in Sisters and Workers in the Middle Ages, Judith M. Bennett, Elizabeth A. Clark, Jean F. O'Barr, B. Anne Vilen and Sarah Westphal-Wihl, editors. Chicago: University of Chicago Press, 1989, pp. 135-60.

Bettey, J. H. "The Suppression of the Benedictine Nunnery at Shaftesbury in 1539." The Hatcher Review 4:34 (1992): 3-11.

Blake, William J. "Fuller's List of Norfolk Gentry." Norfolk Archaeology 32 (1961): 261-91.

Burton, Janet. Monastic and Religious Orders in Britain 1000-1300. Cambridge: University Press, 1994.

Bynum, Carolyn W. Holy Feast and Holy Fast: Religious Significance of Food to Medieval Women. Berkeley: University of California Press, 1987.

Carter, Patrick. "Barking Abbey and the Libaray of William Pownsett: A Bibliographical Conundrum." Transactions of the Cambridge Bibliographical Society 11:3 (1998): 263-71.

Chadwick, Whitney. Women, Art, and Society. $2^{\text {nd }}$ edition. London: Thames and Hudson, 1997.

Clapham, Alfred William, Sir. "The Benedictine Abbey of Barking: A Sketch of its Architectural History and an Account of recent Excavations on the Site." Transactions of the Essex Archaeological Society, 2 (1911): 69-87.

Colker, Marvin L. "Texts of Jocelyn on Canterbury which relate to the history of Barking Abbey." Studia Monastica 7 (1965): 383-460. 
Cooke, Kathleen. "Donors and Daughters; Shaftesbury Abbey's Benefactors, Endowments and Nuns c. 1086-1130." Anglo-Norman Studies: Proceedings of the Battle Conference 12 (1990): 29-45.

Crittall, Elizabeth. "Fragment of an Account of the Cellaress of Wilton Abbey, 1299," in Collectanea, N. J. Williams, editor. London: Devizes, 1956, pp. $142-56$.

Crick, Julia. "The Wealth, Patronage, and Connections of Women's Houses in Late Anglo-Saxon England." Revue bénédictine 109 (1999): 251-69.

Cross, Claire. "The Religious Life of Women in Sixteenth-Century Yorkshire." In Women in the Church, Studies in Church History, 27. W. J. Sheils and Diana Wood, editors. Oxford: Basil Blackwell, 1990, pp. 307-24.

-.... "Yorkshire Nunneries in the Early Tudor Period." In The Religious Orders in Pre-Reformation England. James G. Clark, editor. Woodbridge, England: The Boydell Press, 2002, pp. 145-54.

Cuneo, Pia F. "The Basilica Cycle of Saint Katherine's Convent: Art and Female Community in Early-Renaissance Augsburg." Woman's Art Journal 19:1 (Spring/Summer 1998): 21-5.

Cunich, Peter. "The Ex-Religious in Post-Dissolution Society: Symptoms of PostTraumatic Stress Disorder?" In The Religious Orders in Pre-Reformation England. James G. Clark, editor. Woodbridge, England: The Boydell Press, 2002, pp. 227-38.

Deanesly, Margaret. The Lollard Bible and Other Medieval Biblical Versions. Cambridge: University Press, 1920, reprinted 1966.

Desilets, Roseanne Michalek. "The Nuns of Tudor England: Feminine Responses to the Dissolution of the Monasteries." Ph.D. diss., University of California at Irvine, 1995.

Dolan, Frances E. "Gender and the 'Lost' Spaces of Catholicism." Journal of Interdisciplinary History, 32:4. (Spring, 2002): 641-65.

Doubleday, H. A. and Lord Howard de Walden, editors. The Complete Peerage or a History of the House of Lords and all its Members from the Earliest Times by G.E.C., vol. 9 Moels to Nuneham. London: St. Catherine Press, 1936.

Doyle, A. I. "Books Connected with the Vere Family and Barking Abbey." Transactions of the Essex Archaeological Society 25 (1958): 222-43. 
----. "Publication by Members of the Religious Orders." In Book Production and Publishing in Britain 1375-1475. Jeremy Griffiths and Derek Pearsall, editors. Cambridge: University Press, 1989, pp. 109-23.

Duffy, Eamon. The Stripping of the Altars: Traditional Religion in England c. 1400c. 1580. New Haven and London: Yale University Press, 1992.

Eales, Jacqueline. Women in Early Modern England, 1500-1700. London: University College London Press, 1998.

Eckenstein, Lina. Women Under Monasticism: Chapters on Saint-Lore and Convent Life between A.D. 500 and A.D. 1500. Cambridge, 1896, reissued, New York: Russell \& Russell, Inc., 1963.

Erler, Mary C. Women, Reading, and Piety in Late Medieval England. Cambridge: University Press, 2002.

Essex Record Office (ERO) publication no. 41, Essex Monasteries. Chelmsford: Essex City Council and ERO, 1964.

Faulkner, Ann. "The Harrowing of Hell at Barking Abbey and in Modern Production," In The Iconography of Hell. Clifford Davidson and Thomas $\mathrm{H}$. Seiler, editors. Kalamazoo, MI: Medieval Institute Publications, 1992, pp. $141-57$.

Fell, Christine. Women in Anglo-Saxon England and the impact of 1066. Bloomington, IN: Indiana University Press, 1984.

Gasquet, Francis Aidan, Cardinal. Henry VIII and the English Monasteries. London: John C. Nimmo, 1899.

Gilchrist, Roberta. Gender and Material Culture, The Archaeology of Religious Women. London: Routledge, 1994.

Gilchrist, Roberta and Marilyn Oliva. Religious Women in Medieval East Anglia: History and Archaeology c. 1100-1540. Norwich: Center for East Anglian Studies, University of East Anglia, 1993.

Gillespie, Vincent. "Vernacular Books of Religioin." In Book Production and Publishing in Britain 1375-1475. Jeremy Griffiths and Derek Pearsall, editors. Cambridge: University Press, 1989, pp. 317-44. 
Greatrex, Joan. "On Ministering to 'Certayne Devoute and Religiouse Women': Bishop Fox and the Benedictine Nuns of Winchester Diocese on the Eve of the Dissolution." In Women in the Church, Studies in Church History, 27. W. J. Sheils and Diana Wood, editors. Oxford: Basil Blackwell, 1990, pp. 223-35.

Hamburger, Jeffrey F. Nuns as Artists: The Visual Culture of a Medieval Convent. Berkeley and Los Angeles: University of California Press, 1997.

Harden, Donald B. "A Glass Bowl of Dark Age Date and some Medieval GraveFinds from Shaftesbury Abbey." The Antiquaries Journal 34:3-4 (October 1954): $188-94$.

Harris, Barbara J. "A New Look at the Reformation: Aristocratic Women and Nunneries, 1450-1540." Journal of British Studies 32 (April 1993): 89-113.

Harvey, Barbara. Living and Dying in England 1100-1540: The Monastic Experience. Oxford: Clarendon Press, 1993.

Herlihy, David. Opera Muliebria: Women and Work in Medieval Europe. Philadelphia: Temple University Press, 1990.

Hilpisch, Stephanus. History of Benedictine Nuns. Translated by Sister M. Joanne Muggli. Leonard J. Doyle, editor. Collegeville, MN: St. John's Abbey Press, 1958.

Howson, James. "Books and Barking Abbey," Essex Journal 1 (1966): 197-208.

Hoyle, R. W. "The Origins of the Dissolution of the Monasteries." The Historical Journal 38:2 (1995): 275-305.

Johnson, Penelope D. Equal in Monastic Profession: Religious Women in Medieval France. Chicago: University of Chicago Press, 1991.

Johnston, William M., editor. Encyclopedia of Monasticism. 2 vols. Chicago: Fitzroy Dearborn, 2000.

Knowles, Dom David and R. Neville Hadcock. Medieval Religious Houses England and Wales. London: Longman, 1971.

Knowles, Dom David. The Evolution of Medieval Thought, $2^{\text {nd }}$ edition. D. E. Luscombe and C. N. L. Brooke, editors. Essex: Longman Group Limited, 1988. 
---.. The Religious Orders in England. 3 vols. Cambridge, 1948-9.

Knowles, M. D. "The Matter of Wilton in 1528." Bulletin of the Institute of Historical Research 31 (1958): 92-6.

Kowaleski, Maryanne and Judith M. Bennett. "Crafts, Gilds, and Women in the Middle Ages." In Sisters and Workers in the Middle Ages, Judith M. Bennett, Elizabeth A. Clark, Jean F. O'Barr, B. Anne Vilen and Sarah Westphal-Wihl, editors. Chicago: University of Chicago Press, 1989, pp. 1125.

Litzenberger, Caroline. The English Reformation and the Laity: Gloucestershire, 1540-1580. Cambridge: University Press, 1997.

Locks, Walter A. Barking Abbey in the Middle Ages. London: Elliot Stock, 1913.

Loftus, E. A. and H. F. Chettle. A History of Barking Abbey. Barking: Wilson \& Whitworth, Ltd., 1954.

Logan, F. Donald. "Departure from the Religious Life During the Royal Visitation of the Monasteries, 1535-1536." In The Religious Orders in PreReformation England. James G. Clark, editor. Woodbridge, England: The Boydell Press, 2002, pp. 213-26.

----. Runaway Religious in Medieval England, c. 1240-1540. Cambridge: University Press, 1996.

MacGowan, Kenneth. "Barking Abbey." Current Archaeology 149 (1996): 172-8.

McIntosh, Marjorie Keniston. Autonomy and Community: The Royal Manor of Havering, 1200-1500. Cambridge; New York: Cambridge University Press, 1986.

McNamara, Jo Ann Kay. Sisters in Arms: Catholic Nuns Through Two Millennia. Harvard University Press, Cambridge, MA, 1996.

----. The Ordeal of Community. Toronto, Ontario: Peregrina, 1993.

Merriman, Roger Bigelow. Life and Letters of Thomas Cromwell, vol. 1. Oxford: Clarendon Press, 1968.

Midmer, Roy. English Mediaeval Monasteries (1066-1540). Athens: University of Georgia Press, 1979. 
Monasticon Anglicanum, vol. 1. Translated by Sir William Dugdale. London, 1693

Newman, Barbara. "The Cattes Tale: A Chaucer Aopcryphon." The Chaucer Review 26:4 (1992): 411-23.

Oliva, Marilyn. "Aristocracy or Meritocracy? Office-holding Patterns in Late Medieval English Nunneries." In Women in the Church, Studies in Church History, 27. W. J. Sheils and Diana Wood, editors. Oxford: Basil Blackwell, 1990, pp. 197-208.

-.--. "Patterns of Patronage to Female monasteries in the Late Middle Ages," in The Religious Orders in Pre-Reformation England, James G. Clark, ed.

Woodbridge, England: The Boydell Press, 2002, pp. 155-62.

-.--.. The Convent and the Community in Late Medieval England: Female Monasteries in the Diocese of Norwich, 1350-1540. Woodbridge: The Boydell Press, 1998.

Oxley, J. E. The Reformation in Essex to the Death of Mary. Manchester: The University Press, 1965.

Palmer, M. D. Henry VIII, Seminar Studies in History. Roger Lockyer, general editor. London: Longman, 1983.

Paxton, Catherine. "The Nunneries of London and its Environs in the later Middle Ages." Ph.D. diss., Oxford University, 1992.

Powell, W. Raymond, H. A. Doubleday, Wm. Page, and John H. Round, editors. The Victoria History of the County of Essex. Victoria History of the Counties of England, Vol. 2. Folkestone: Published for the University of London, Institute of Historical Research by Dawsons, 1977-.

Power, Eileen. Medieval English Nunneries c. 1275 to 1535. Cambridge, 1922, reissued, New York: Biblo and Tannen, 1964.

-.--r. Medieval Women. M. M. Postan, editor. Cambridge: University Press, 1975.

Rudy, Kathryn M. "A Pilgrim's Book of Hours: Stockholm Royal Library A233." Studies in Iconography 21 (2000): 237-63.

---.-. "A Guide To Mental Pilgrimage: Paris, Bibliothèque de L'Arsenal Ms. 212." Zeitschrift für Kunstgeschichte 63 (2000): 494-515. 
Schama, Simon. A History of Britain: At the Edge of the World? 3000BC-AD1603. New York: Hyperion, 2000.

Schulenburg, Jane T. "Strict Active Enclosure and Its Effects on Female Monastic Experience (ca. 500-1200)." In Medieval Religious Women. John A. Nichols and Lillian T. Shank, editors, vol. 1, Distant Echoes. Kalamazoo, Mich.: Cistercian Publications, 1984, pp. 51-86.

Sekules, Veronica. Medieval Art. Oxford: University Press, 2001.

Shahar, Shulamith. The Fourth Estate: A History of Women in the Middle Ages. New York: Methuen \& Co., 1983.

Sharpe, R., J. P. Carley, R. M. Thomson, and A. G. Watson, editors. English Benedictine Libraries: The Shorter Catalogues. London: The British Library, 1996.

Skinner, Mary. "Benedictine Life for Women in Central France, 850-1100: A Feminist Revival." In Medieval Religious Women. John A. Nichols and Lillian T. Shank, editors, vol. 1, Distant Echoes. Kalamazoo, Mich.: Cistercian Publications, 1984, pp. 87-113.

Sturman, Winifrid M. "Barking Abbey: A Study in its external and internal administration from the Conquest to the Dissolution." Ph.D. diss., University of London, 1961.

Sydenham, Laura. Shaftesbury and its Abbey. The Oakwood Press, 1959, reprinted, 1978.

The Camden Miscellany. Vol. 32. London: The Camden Society, 1847-.

Thompson, Benjamin. "Monasteries, Society and Reform in Late Medieval England." In The Religious Orders in Pre-Reformation England. James G. Clark, editor. Woodbridge, England: The Boydell Press, 2002, pp. 165-95.

Thompson, Sally. Women Religious: The Founding of English Nunneries after the Norman Conquest. Oxford: Clarendon Press, 1991.

Uitz, Erika. The Legend of Good Women: The Liberation of Women in Medieval Cities. London: Moyer Bell, 1994.

Venarde, Bruce L. Women's Monasticism and Medieval Society: Nunneries in France and England, 890-1215. Ithaca, NY: Cornell University Press, 1997. 
Warren, Ann K. Anchorites and Their Patrons in Medieval England. Berkeley: Univ. of California Press, 1986.

----. "The Nun as Anchoress: England 1100-1500," In Medieval Religious Women. John A. Nichols and Lillian T. Shank, editors, vol. 1, Distant Echoes. Kalamazoo, Mich.: Cistercian Publications, 1984, pp. 197-212.

Warren, Nancy Bradley. Spiritual Economies: Female Monasticism in Later Medieval England. Philadelphia: University of Pennsylvania Press, 2001.

Wiesner, Merry E. Women and Gender in Early Modern Europe. Second edition. Cambridge: University Press, 2000.

Woodford, Charlotte. Nuns as Historians in Early Modern Germany. Oxford: Clarendon Press, 2002.

Woodward, G. W. O. The Dissolution of the Monasteries. New York: Walker and Company, 1967.

Woolgar, C. M. The Great Household in Late Medieval England. New Haven: Yale University Press, 1999.

Wright, Thomas, editor. Three Chapters of Letters relating to the Suppression of the Monasteries. London: John Bowyer Nichols and Son, 1843.

Youings, Joyce. The Dissolution of the Monasteries. London: George Allen and Unwin Ltd., 1971.

Young, Karl. The Drama of the Medieval Church, vol. 1. Oxford: Clarendon Press, 1933, reprinted 1951.

\section{Internet Sources}

2002 National Politics Web Guide. "Humphrey Duke of Gloucester," 14 February 2003, <http://lego 70.tripod.com/england/humphrey gloucester.htm $>$ (15 November 2003).

Castelli, Jorge. "Mordaunt Family." n.d. $<$ http://www.tudorplace.com.ar/MORDAUNT.htm\#Winifred\%20MORDAU NT1> (23 December 2003). 
----. "Drury Family," n.d.

$<$ http://www.tudorplace.com.ar/DRURY.htm\#Robert $\% 20 D R U R Y \% 200 f \% 2$ 0Hawstead\%20(Sir)1 > (7 January 2004).

-.-.. "Drury Family." n.d.

$<$ http://www.tudorplace.com.ar/DRURY.htm\#Joan\%20DRURY1> (7 January 2004).

---.. "Henry Barley of Albury." n.d.

$<$ http://www.tudorplace.com.ar/Bios/HenryBarley.htm> (8 January 2004).

Cunich, Peter. "Monastic Database for England and Wales in the Sixteenth Century." 29 February 2000.

$<$ http://www.hku.hk/history/cunich/monast2.html $>$ (8 January 2004).

"Descendants of Robert Duke." n.d.

$<$ http://freepages.genealogy.rootsweb.com/ trotter/duke.htm> (8 January 2004).

LoveToKnow Corporation. "Robert Fabyan." n.d. $<$ http://33.1911encyclopedia.org/F/FA/FABYAN_ROBERT.htm> $>(8$ January 2004).

Reid, George J. The Catholic Encyclopedia, vol. I. "Acta Pilati." 15 September 2003. <http://www.newadvent.org/cathen/01111b.htm> (22 January 2004).

Richard III Society, American Branch. "Privy Purse Expenses of Elizabeth of York: Wardrobe Accounts of Edward IV, Part 16.2: Index and Notes for Privy Purse Expenses, Baybroke through Christenings." 12 April 1996. $<$ http://www.r3.org/bookcase/wardrobe/purnote2.html > (9 January 2004).

"Selected Families and Individuals." n.d.

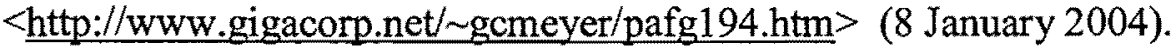

Stevenson, Tom. "Joan Drury." 21 October 2002.

$<$ http://worldconnect.genealogy.rootsweb.com/cgibin/igm.cgi?op $=$ GET \&db=thomass\&id $=I 14031>(7$ January 2004).

The Columbia Encyclopedia, Fifth Edition, 1994-5. "Humphrey Duke of Gloucester," n.d., $<$ http://www.slider.com/enc/22000/Gloucester Humphrey duke of.htm $>$ (15 November 2003). 
Townshend, Derek. "Sir Roger Townshend." n.d.

$<$ http://home.worldonline.co.za/ townshend/judgeroger.htm $>$ (3 January 2004). 


\section{APPENDIX A}

Map of Barking Abbey from the twelfth to the fifteenth century

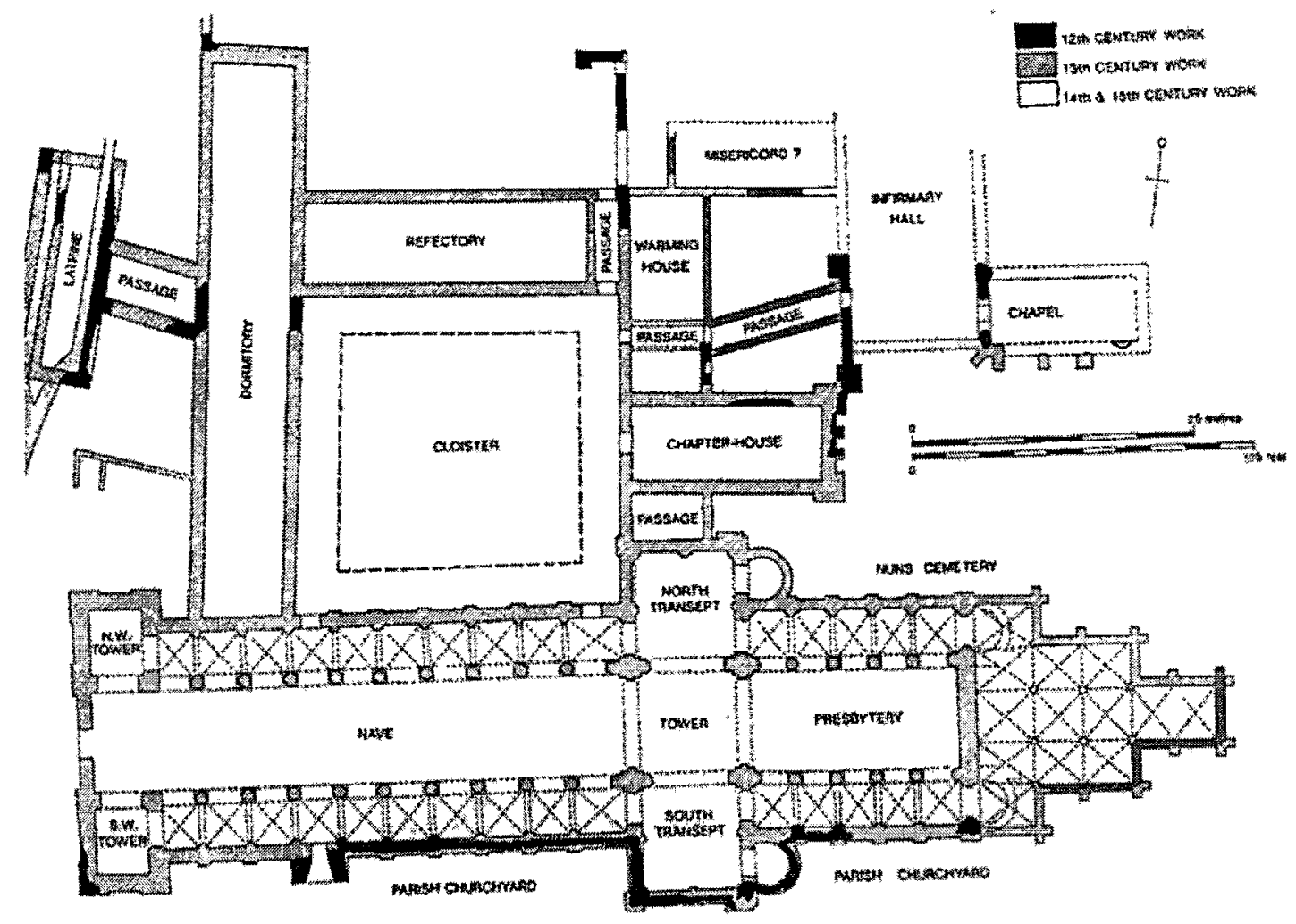

Source: Roberta Gilchrist, Gender and Material Culture, The Archaeology of Religious Women (London: Routledge, 1994), 114. 


\section{APPENDIX B}

The Pensions Office Account Book gives the following census: ${ }^{1}$

$\begin{array}{ll}1508-9 & 39 \text { nuns } \\ 1514-15 & 37 \text { nuns } \\ 1515-16 & 39 \text { nuns } \\ 1516-18 & 38 \text { nuns } \\ 1519-22 & 37 \text { nuns } \\ 1522-3 & 36 \text { nuns } \\ 1523-6 & 38 \text { nuns } \\ 1526-7 & 37,27 \text { nuns } \\ 1527-9 & 28 \text { nuns } \\ 1529-30 & 30 \text { nuns } \\ 1530-1 & 30 \text { nuns, } 4 \text { novices } \\ 1531-2 & 29 \text { nuns, } 4 \text { novices } \\ 1532-3 & 28 \text { nuns, } 4 \text { novices } \\ & 29 \text { nuns, } 2 \text { novices } \\ 1533-4 & 30 \text { nuns } \\ 1534-5 & 30 \text { nuns, } 4 \text { novices } \\ 1535-6 & 33 \text { nuns, } 1 \text { novice } \\ 1536-7 & 30 \text { nuns, } 4 \text { novices } \\ 1537-8 & 32 \text { nuns, } 3 \text { novices } \\ 1538-9 & 29 \text { nuns, } 2 \text { novices } \\ & 30 \text { nuns }\end{array}$

'Oxley, p. 282. 


\section{APPENDIX C}

Barking Abbey nuns present at the suppression in 1539:

Abbess, Dorothy Barley

Elizabeth Badcock

Margery Ballard

Elizabeth Banbrik

Margaret Bramston

Agnes Buknam

Margaret Cotton

Joan Drurye

Martha Fabyan

Dorothy Fitzlewes

Joan Fyncham

Matilda Gravell

Margaret Grenehyll

Agnes Horsey

Alice Hyde

Thomasina Jenney

Margaret Kempe

Lucy Long

Audrey Mordaunt

Winifred Mordaunt

Margery Paston

Katharine Pollard

Elizabeth Prist

Margaret Scrope

Gabrielle Shelton

Anne Snowe

Suzanna Sulyard

Agnes Townesend

Mary Tyrell

Ursula Wentworth

Elizabeth Wyott. ${ }^{2}$

${ }^{2} \mathrm{VCH}, 120$. 
APPENDIX D

Surviving manuscripts in the library of Barking Abbey. ${ }^{3}$

1. Beeleigh Abbey, Miss C. Foyle s.xv ${ }^{\text {in }}$

a. (fol. 3) Nicholas Love, Mirror of the Blessed Life of Christ (Speculum vitae Christi) (L/B/E 553); b. (fol. 169v) William Flete, De remedies contra temptations (a variant of the first Middle English version) (Jolliffe K.8.[a]; L/B/E 230,528).

2. Cambridge, Trinity College $1226(0.3 .54)$ s.xv

Hymnary (with music) for proprium de tempore, proprium sanctorum, and commune sanctorum (imperfect at end).

3. ?Cardiff, Public Library 1.381 folios $81-146 \mathrm{s.xii}{ }^{\text {in }}$-xiii

Collection of seven vitae sanctorum: a. (fol. 81) Goselin, Life of St. Ethelburga (BHL 2630b); b. (fol. 94) Life of St. hildelitha (BHL 3942); c. (fol. 97) Life of St. Edward the Martyr (BHL 2418); d. (fol. 102v) Goscelin, Life of St. Edith (BHL 2107); f. (fol. 130) Hildebert of Lavardin, Metrical Life of St. Mary of Egypt (BHL 5419; Walther 18159); g. Life of St. Ebrulfus (BHL 2377).

4. ?Cardiff, Public Library 3.833 s.xiii ${ }^{\text {ex }}$

a. (fol. 1) Defensor of Ligugé, Scintillarium (CPL 1302); b. (fol. 46) brief theological tracts and commonplaces, including an anonymous $D e$ sacramento altaris, ps. - Jerome, De xv signis, De decem plagis Egypti (Walther 14585), and an extract from Augustine's De doctrina Christiana (PL 34: 82-90); c. (fol. 61) John Beleth, Summa de ecclesiasticis officiis (ed. H. Douteil, CCCM 41, 41A [1976]); d. (fol. 150) Summa de vitiis et virtutibus (Bloomfield 5449); (fol. 1 [s.xiii ${ }^{\mathrm{ex}}$ ]) Liber sancta Adelbure de $<$ Barking $>$, qui ipsum alienauerit, anathema sit. Amen.

5. London, B.L. Add. 10596, fols. 25-83 s.xv

a. (fol 25) Wycliffite translation of the book of Tobit in the revision traditionally ascribed to John Purvey (L/B/E 119); b. (fol. 47v) Magnificat and Benedictus, both in the later Wycliffite version; c. (fol. 49) An anonymous and unprinted 'deuout meditacioun ... on the godenes of oure blessed lord' (Revell 6); d. (fol. 54v) Unprinted prayers in English to Jesus and various saints (Revell 263, 323-9, 331-8); e. (fol. 77) Wycliffite

\footnotetext{
${ }^{3}$ Printed in David Bell, pp. 107-20 and Mary Erler, p. 145. A listing of the printed books without the manuscripts is also published in English Benedictine Libraries, 14-16 and Carter, 269-71.
} 
translation of the book of Susanna in the revision traditionally ascribed to John Purvey (L/B/E 119); f. (fol. 82v) Two pages of prayers in Latin to mater Ethelburga, patroness of Barking (imperfect at beginning and end), inscribed at head of the folio in red: Iste liber constat Matilde Hayle de Berkinge, followed by inscription at the foot in black: Iste liber constat $D<$ omine $>$ Marie Hastyngs de Berkynge.

6. ?London, B.L., Cotton Julius D.viii fols. 40-47v s.xv

This ys the Charthe longynge to the office off the Celeresse of the monestary of Barkynge as heraffter folowethe

7. London, B.L., Cotton Otho A.v s.xiv ${ }^{\mathrm{ex}}$

This manuscript originally contained a paschal table, a Calendar, and an explanation of the Calendar in English, but most of the manuscript was destroyed in the Cotton Fire of 1731. Only five damaged folios remain: two of the Calendar and three of the table.

8. London, Lambeth Palace 1495.4 (printed book)

Vitas patrum (in English, and attributed to Jerome), printed by Wynkyn de Worde, Westminster, 1495 (STC 14507; Duff 235). (fol. 1 [s.xvi ]) inscribed Thys bouke belongyth to Martha ffabyan (fol. CCCxlvij) This bouke belongyth to Martha ffabyan.

9. ?Nijmegen, U.L. 194 (fols. 41-104 s.xv)

A collection of prayers and devotional material in Latin and English, beginning with prayers (in Latin) to five saints, including Ethelburga and Hildelitha.

10. Oxford, Bod. Library, Bodl. 155 (S.C. 1974) s.x/xi

The four gospels (in Latin) with Jerome's prefaces and the 'Ammonian' sections of Eusebius in the margins. At the end is a list of liturgical gospels for the year preceded by an argumentum.

11. Oxford, Bod. Library, Bodl. 923 (S.C. 27701) s.xiv ${ }^{2}$

The Cleansing of Man's Soul (Jolliffe E.14), edited from this manuscript by C. L. Regan (Harvard Univ., Ph.D. Diss., 1963). (fol. 153v) inscribed: Anno domini 1401, followed on the next line and in a different hand by: Iste liber constat Sibille de Feltoun abbatisse de Berkyng.

12. Oxford, Bod. Library, Laud lat. 19 s.xii [b.3]

a. (fol. 1v) Song of Songs, with gloss; b. (fol. 34v) Lamentations with gloss. (fol. 1 [s.xiii ${ }^{1}$ ) inscribed: Hic est liber sacratissime Dei genitricis Marie, et beate Aethelburge uirginis Berkingensis ecclesie, quem qui abstulerit aut super eo fraudem fecerit, anathematis mucrone feriatur. 
13. Oxford, Magdalen College, lat. $41 \mathrm{s.xv}$

This manuscript contains a large collection of devotional and moral works in French. See David Bell, What Nuns Read, pp. 112-115 for complete list.

14. Oxford, University College, 169 s.xiv/xv

An Ordinal, preceded by an incomplete Calendar (November and December missing) for the use of the nuns of Barking. (fol. $6 \mathrm{v}\left[\mathrm{s.xv} \mathrm{v}^{\mathrm{in}}\right]$ ) inscribed: Memorandum quod anno Domini millesimo quadragintesimo quarto domina Sibilla, permissione diuina abbatissa de Berkyng, hunc librum ad usum abbatissarum in dicta domo in futurum existencium concessit et in librario eiusdem loci post mortem cuiuscumque in perpetuum commoraturum ordinauit, donec eleccio inter moniales fiat, tunc predictus liber eidem electe in abbatissam per superiores domus post stallacionem deliberetur.

15. Paris, B.N., Fr. 1038 s.xiii/xiv

a. (fol. 1) Vies des pères; b. (fol. 110) Les voyages de saint Antoine; c. (fol. 114) Ps.-John of Damascus, L'Histoire de Barlaam et Josaphat (Bossuat 3216, 6624; BHL 979); d. (fol. 162) Adso of Montier-en-Der, La légende de l'Antéchrist; e. (fol. 164) A brief text entitled Si comme Nostre Sires vendra jugier le monde, inc. 'Quant .xl. jorz seront passez après la mort Antecrist'; $\mathbf{f}$. (fol. 164) L'assomption de Notre Dame (this is a translation of ps.-Melito of Sardis, Transitus beatae Mariae Virginis, versio Latina $B$ [Stegmüller 164,5; BHL 5352]). (fol. 4 [s.xv ${ }^{\text {in }}$ ) inscribed: Cest liuere achata dame Sibille de Feltonne, abbesse de Berkyng, de les executurs de dame Philippe Coucy, duchesse d'Irland et contesse d'Oxenford.

16. London, B.L., Harley 100

A psalter and book of hours attributed to Barking due to the inscription in the calendar on October 11, in die sancta ethelburge de Berkyng. The litany (fol. 145) lists saints Etheldreda, Mildreda, Wythburga, Sexburga, Radegundis, but not St. Ethelburga or London saints.

The twenty-one items below are the printed texts from the list included in William Pownsett's estate entitled "Certayne bookes yn the Abbey of Barkynge:"

1. In primis $\mathbf{a}$ Virgill and $\mathbf{b}$ Tullis offices with a comment

2. Item $\mathbf{a}$ a booke de modo confitendi and $\mathbf{b}$ a bible in lattyn

3. Item a booke de causa boemica

4. Item an enchiridion militis Christi

5. Item Isopps fabels

6. Item a booke called Gemma predicantium

7. Item a book called Vocabulus utriusque iuris 
8. Item ij bookes $\mathbf{a}$ one of the decres of the lawe, $\mathbf{b}$ the other of the distinctions of the law

9. Item a booke de epistola Nicholai lier

10. Item ij bookis of Sermones

11. Item one booke called Destructorium vitiorum

12. Item one booke called Cathalogus Sanctorum

13. Item a book called Hamo super epistolas Pawli

14. Item $\mathbf{a}$ one book called casus Barnerdi \& $\mathbf{b}$ an other called Racionale diuinorum officinorum

15. Item a book super epistolas chanonicas

16. Item $\mathbf{a}$ one called summa Hostensis and $\mathbf{b}$ nother called testus Sentenciarum

17. Item a a book called decem libri ethnorum, $\mathbf{b}$ an other called opus aureum sanctorum, and $\mathbf{c}$ another called summa aurea

18. Item one book called Tartaret

19. Item a book called Thomas primus opus Dionisii

20. Item a book called Dionisyus super spalmos

21. Item a book called Dionysyus super iiij ${ }^{\text {or Euangelia }}$ 